\title{
Gene expression regulation in the plant growth promoting Bacillus atrophaeus UCMB-5137 stimulated by maize root exudates
}

Liberata Mwita ${ }^{1}$, Wai Yin Chan $^{2}$, Theresa Pretorius ${ }^{2}$, Sylvester L. Lyantagaye ${ }^{3}$, Svitlana V. Lapa ${ }^{4}$, Lilia V. Avdeeva $^{4}$, Oleg N. Reva ${ }^{{ }^{*}}$

${ }^{1}$ Centre for Bioinformatics and Computational Biology, Dep. Biochemistry, University of Pretoria, Lynnwood Rd, Hillcrest, Pretoria 0002, South Africa.

${ }^{2}$ Department of Microbiology and Plant Pathology, University of Pretoria, Lynnwood Rd, Hillcrest, Pretoria 0002, South Africa.

${ }^{3}$ Department of Molecular Biology and Biotechnology, College of Natural and Applied Sciences, University of Dar es Salaam, P.O. Box 35179, Dar es Salaam, Tanzania.

${ }^{4}$ Dep. Antibiotics, D. K. Zabolotnogo Institute of Microbiology and Virology, 154 Zabolotnogo Str., Kiev, Ukraine.

"For correspondence: oleg.reva@up.ac.za, phone +27-12420-5810; fax: +27-12420-5800;

\begin{abstract}
Despite successful use of Plant Growth Promoting Rhizobacteria (PGPR) in agriculture, little is known about specific mechanisms of gene regulation facilitating the effective communication between bacteria and plants during plant colonization. Active PGPR strain B. atrophaeus UCMB-5137 was studied in this research. RNA sequencing profiles were generated in experiments where root exudate stimulations were used to mimic interactions between bacteria and plants. It was found that the gene regulation in B. atrophaeus UCMB-5137 in response to the root exudate stimuli differed from the reported gene regulation at similar conditions in B. amyloliquefaciens FZB42, which was considered as a paradigm PGPR. This difference was explained by hypersensitivity of UCMB-5137 to the root exudate stimuli impelling it to a sessile root colonization behavior through the CcpA-CodY-AbrB regulation. It was found that the transcriptional factor DegU also could play an important role in gene regulations during plant colonization. A significant stress caused by the root exudates on in vitro cultivated B. atrophaeus UCMB-5137 was noticed and discussed. Multiple cases of conflicted gene regulations showed scantiness of our knowledge on the regulatory network in Bacillus. Some of these conflicted regulations could be explained by interference of non-coding RNA (ncRNA). Search through differential expressed intergenic regions revealed 49 putative loci of ncRNA regulated by the root exudate stimuli. Possible target mRNA were predicted and a general regulatory network of $B$. atrophaeus UCMB-5137 genome was designed.
\end{abstract}




\section{Highlights}

- Plant colonizing PGPR Bacillus responded differently to the root exudate stimuli;

- In UCMB-5137 the CcpA-CodY-AbrB regulation caused fast cell immobilization;

- DegU regulon is important for plant colonization behavior in PGPR Bacillus;

- ncRNA involved in regulation of plant colonization were identified;

- A comprehensive model of gene regulation in UCMB-5137 was developed;

Keywords Plant growth promoting rhizobacteria; transcriptomics; RNA sequencing; transcriptional regulatory network; non-coding RNA

\section{Abbreviations}

GABA, gamma-aminobutyric acid; mRNA, messenger RNA; ncRNA, non-coding RNA; PGPR, Plant Growth Promoting Rhizobacteria; (p)ppGpp, guanosine pentaphosphate; rRNA, ribosomal RNA.

\section{Introduction}

Diverse group of bacteria inhabiting plant rhizosphere and directly or indirectly enhancing the plant growth was termed in the literature as Plant Growth Promoting Rhizobacteria (PGPR) (Lugtenberg \& Kamilova, 2009). Rhizosphere provided these bacteria with a source of energy and organic compounds from plants (Sivasakthi et al., 2014). In return, bacteria supplied plants with certain nutrients and protection from plant pathogens (Glick 1995). Successful plant colonization by PGPR relied on multiple factors including but not limited to withstanding environmental stress (Reva et al., 2004), efficient chemotaxis (Yssel et al., 2011), effective communication within the bacterial communities and between bacteria and plants carried out by synthesized plant hormones and quorum sensing autoinducers (Lengeler \& Postma 1999; Farag et al., 2013). All the factors are directly or indirectly related to effective sensing of environmental signals and proper regulation of gene expression.

Utilizing PGPR for plant growth promotion was recognized as a potential alternative to chemical preparations. In contrast to chemical fertilizers and pesticides, PGPR were considered to be safe to humans and friendly to the environment and resident soil microorganisms (Vessey 2003; Bashan \& de-Bashan, 2005; Sivasakthi et al., 2014). For an effective usage of biofertilizers and biopesticides based on PGPR, it is important to understand better the genetic mechanisms underlying the interactions of these bacteria with the host plants at early stages of rhizosphere colonization.

Bacillus strains are common in rhizosphere communities (Podile \& Kishore 2007; Fan et al., 2013). However, only a few studies on gene regulation in PGPR Bacillus have been reported. Differential gene expression regulations caused by the maize root exudates were reported previously on Bacillus amyloliquefaciens FZB42 that was proposed as paradigm of PGPR Bacillus (Fan et al., 2012; Kierul et al., 2015). Gene regulation in Bacillus subtilis BSB1 under abiotic stresses was reported by Kohlstedt et al. (2014). It was not clear whether these reports could be extended to other PGPR Bacillus, as it had been found that the activities of biotechnological importance were strain specific (Safronova et al., 2012). There was little knowledge regarding plant colonization behavior of other bacteria of the B. subtilis group, such as B. atrophaeus. The strain B. atrophaeus UCMB-5137 was isolated from rhizosphere 
in Ukraine in 1989 and at first, based solely on the phenotype; it was identified as B. subtilis. In an array of bioassays, B. atrophaeus UCMB-5137 showed ability to protect plants and crops from bacterial and fungal phytopathogens, and to promote the plant growth (Lapa \& Reva, 2005). Complete genome sequence of B. atrophaeus UCMB-5137 has been achieved recently (Chan et al., 2013). B. atrophaeus is a common soil inhabitant. Spores of B. atrophaeus have been used in biotechnology to control sterilization processes because of the resistance of the spores to extreme temperatures and chemical detergents (Pinzón-Arango et al., 2009). Except for UCMB-5137, the strains of B. atrophaeus were not reported in the literature as active plant associated growth promoters or protectors, in contrast to the strains of the closely related species B. amyloliquefaciens and B. subtilis. This brought our interest to study this bioactive strain UCMB-5137 to contribute to the knowledge on the gene regulation in PGPR Bacillus. Current knowledge on this issue is biased towards the paradigm examples of B. amyloliquefaciens ssp. plantarum (Reva et al., 2004; Chen et al., 2007; Fan et al., 2011; 2012; 2013; 2015).

In various studies it was demonstrated that the maize root exudates were useful to mimic in vitro interactions between different plants and PGPR by initiating a range of biological responses within the bacteria (Mark et al., 2005; Broeckling et al., 2008; Fan et al., 2012; Kierul et al., 2015). It was therefore interesting to study further the gene expression regulation in B. atrophaeus UCMB-5137 under the standard laboratory conditions by simulation with the root exudates, to compare the gene expression profile with the published results for other PGPR Bacillus. Differential transcription regulation stimulated by the root exudates in B.atrophaeus UCMB-5137 and B. amyloliquefaciens FZB42 revealed substantial differences between these bacteria. To identify other transcription factors and genes specifically involved in root colonization by B. atrophaeus UCMB-5137, the obtained gene regulation profiles were superimposed over known regulatory networks in B. subtilis (Kohlstedt et al., 2014; Michna et al., 2015). Possible involvement of non-coding RNA (ncRNA) in gene regulations during plant colonization was studied.

\section{Materials and methods}

\subsection{Root exudate preparation}

Root exudates were extracted from maize roots as it was described by Fan et al. (2012). Seeds of the maize breed 5Q-751BR were surface sterilized by treating the seeds with 70\% ethanol for $3 \mathrm{~min}$ and then with $5 \%(\mathrm{v} / \mathrm{v}$ ) sodium hypochlorite for $3 \mathrm{~min}$ followed by rinsing 5 times with sterile distilled water. The seeds were germinated at $28^{\circ} \mathrm{C}$ until the main root was at least $2 \mathrm{~cm}$ long before transferring into test tubes with sterilized water in a way that only the roots were submerged into water. The test tubes were kept in plant growth chamber $\left(16-\mathrm{h}\right.$ light $/ 8$-h dark) at $24^{\circ} \mathrm{C}$ for 8 days. Water aliquots were collected daily from the third to eighth day and the tubes were refilled with the same amount of fresh sterilized water. Each collection was kept separate, and $100 \mu \mathrm{L}$ from each sample were spread on the nutrient agar to check for contamination. Contaminated root exudate samples were discarded and the clean samples were pooled, freeze dried and stored at minus $20^{\circ} \mathrm{C}$. The lyophilized exudates were weighted, dissolved in $100 \mu \mathrm{L}$ of water and centrifuged. The supernatant was filter sterilized. Concentrations of the root exudates were adjusted to $0.25 \mathrm{~g} / \mathrm{L}$ and the solutions were kept as the stock at minus $80^{\circ} \mathrm{C}$. 


\subsection{Bacterial growth conditions and RNA preparation}

Bacillus atrophaeus UCMB-5137 was obtained from the Ukrainian collection of microorganisms at Danylo Zabolotny Institute of Microbiology and Virology, National Academy of Science of Ukraine, Kyiv, Ukraine.

Bacterial cultures were inoculated from a frozen stock culture and incubated at $37^{\circ} \mathrm{C}$ overnight on solid Luria agar medium (MERCK). Colonies from the overnight culture were inoculated into $1 \mathrm{C}$ medium and cultivated at $24^{\circ} \mathrm{C}$ for 14 hours with shaking at $180 \mathrm{rpm}$. Composition of the $1 \mathrm{C}$ medium was the same as suggested by Fan et al. (2012): $0.7 \% \mathrm{w} / \mathrm{v}$ pancreatic digest of casein, $0.3 \% \mathrm{w} / \mathrm{v}$ papain digest of soya flour, $0.5 \% \mathrm{w} / \mathrm{v} \mathrm{NaCl}$ and $0.1 \%$ glucose (all the mentioned reagents were purchased from MERCK). $1 \mathrm{ml}$ aliquots of the overnight cultures were inoculated into conical flasks with $20 \mathrm{ml}$ of fresh $1 \mathrm{C}$ medium in control, and supplemented with $0.25 \mathrm{mg} / \mathrm{ml}$ of the maize root exudates in treatment. Control and treatment cultures were grown at $24^{\circ} \mathrm{C}$ for 14 hours 30 min with shaking at 180 rpm to achieve the transition to stationary growth phase, which was controlled by the medium opacity of $\mathrm{OD}_{600} \approx 1.0$ units. Growth curve analysis showed that the bacterial cultures reached the transition to stationary phase in average after $14 \mathrm{hr} 30 \mathrm{~min}$ of cultivation at $24^{\circ} \mathrm{C}$ with shaking $\left(\mathrm{OD}_{600} \approx 1.0\right.$ units) at both treatment and control conditions. Bacterial cells were harvested for the total RNA extraction by mixing with 2 volumes of the ice cold killing buffer $\left(20 \mathrm{mM}\right.$ Tris- $\mathrm{HCl}$ from BDH Laboratory, $5 \mathrm{mM} \mathrm{MgCl}_{2}$ from $\mathrm{MERCK}$ and $20 \mathrm{mM} \mathrm{NaN}_{3}$ from SIGMA; pH was adjusted to 7.5) (Völker et al., 1994). The mixture was centrifuged at 5,000 rpm for 3 minutes at room temperature. The final pellet was washed with $1 \mathrm{ml}$ of the killing buffer and immediately frozen at minus $80^{\circ} \mathrm{C}$ until the RNA extraction. Six RNA samples (3 controls and 3 treatments) were obtained from three independent experiments. However, one sample of the treated bacteria did not pass the RNA quality control and was discarded.

\subsection{Total RNA extraction and sequencing}

Total RNA were isolated using ZR Fungal/Bacteria RNA Mini Prep kit from Zymo research Corp. according to the manufacturer's instruction. Concentration and quality of RNA samples were checked by NanoDrop. Ribolock Ribonuclease inhibitor (Thermo Scientific) was added to prevent RNA degradation. Paired-end RNA sequencing was performed on the MiSeq Illumina platform in Inqaba Biotech (Pretoria, South Africa, http://www.inqababiotec.co.za/). RNA-Seq datasets and the results of the statistical analysis by CLC Genomics Workbench 7 were deposited in NCBI GEO database under the accession number GSE68543.

The RNA-Seq reads were trimmed from the adapter sequences and mapped against the predicted coding and noncoding loci of the reference genome sequence of B. atrophaeus UCMB-5137 (CP011802) using CLC Genomics Workbench 7.0.3 (currently this program is distributed by QIAGEN - http://www.clcbio.com/products/clcgenomics-workbench/). Estimated Degree of Gene Expression statistics approach (Magoc et al., 2013) was used to identify up- and down-regulated genes. Different cutoff values of the fold change and p-values were applied as explained below.

\subsection{Complete genome sequence of $B$. atrophaeus UCMB-5137}

A draft genome sequence of B. atrophaeus UCMB-5137 (NZ_CM001847.1) comprising 21 contigs was obtained recently by Illumina HiSeq sequencing (Chan et al., 2013). DNA reads obtained by RNA-Seq for the current work were used for gap closing and resolving ambiguities in the previous assembly by mapping reads to contigs by CLC 
Genomics Workbench 7.0.3. Prediction of coding genes in the complete genome sequence was performed by using the RAST Genome annotation robot (Aziz et al., 2008) and then checked manually. Nomenclature of the gene names, where it was possible, was adopted from that of B. subtilis 168 (NC_000964). Locations of prophages and other horizontally transferred genomic islands were identified in the genome by using the SeqWord Genome Island Sniffer program (Bezuidt et al., 2009).

\subsection{Gene orthology and phylogenetic studies}

Orthologous genes in the genomes of B. atrophaeus UCMB-5137, B. amyloliquefaciens ssp. plantarum FZB42 (NC_009725), B. amyloliquefaciens ssp. plantarum Y2 (NC_017912), B. amyloliquefaciens ssp. plantarum CAU B946 (NC_016784), B. amyloliquefaciens ssp. plantarum IT-45 (NC_020272), B. amyloliquefaciens ssp. amyloliquefaciens DSM7 (NC_014551), B. subtilis ssp. subtilis 168 (NC_000964), B. subtilis ssp. subtilis BSn5 (NC_014976), B. subtilis ssp. spizizenii TU-B-10 (NC_016047), B. atrophaeus 1942 (NC_014639), B. atrophaeus C89, B. atrophaeus 9372-1, B. atrophaeus 9372-2, B. atrophaeus Dugway, B. atrophaeus Detrick-1, B. atrophaeus Detrick-2, B. atrophaeus Detrick-3, B. atrophaeus 1013-1, B. atrophaeus 1013-2, B. atrophaeus 49822-1, B. atrophaeus 49822-2, B. atrophaeus BACI051-E and B. atrophaeus BACI051-N were identified by EDGAR software platform (Blom et al., 2009). The strains with NC (RefSeq) accession numbers were downloaded from the NCBI database (ftp://ftp.ncbi.nih.gov/genomes/Bacteria/) and the genomes of other strains were obtained from PATRIC (Wattam et al., 2014; http://patricbrc.vbi.vt.edu/portal/portal/patric/Home). The identified groups of orthologous genes were used for superimposition of the gene regulation profiles obtained in this work and those known from the literature. A super-alignment of 856,373 amino acid residues of concatenated alignments of orthologous proteins was used to determine the phylogenetic position of the strain UCMB-5137 by the neighborjoining clustering algorithm implemented in MEGA 6.0.6 (Tamura et al., 2013).

\subsection{Gene co-expression analysis}

Operons were predicted as syntenies of genes transcribed in the same direction with the spacer regions between genes smaller than $200 \mathrm{bp}$. It was assumed that the operon was regulated, if it comprised at least one gene regulated by more than 2 folds in comparison to the control condition with a calculated p-value $\leq 0.05$ and without contradictions to the regulations of other genes in the operon. The 2 folds threshold was used in this case to make the results comparable with the stress response regulation patterns published by Sappa et al. (2013) and Kohlstedt et al. (2014). Operon predictions and their transcriptional regulations were checked by using the SubtiWiki Web-based resource (Michna et al., 2015). Putative transcription regulation binding sites were identified by using the software tools provided by DBTBS server (Sierro et al., 2008; http://dbtbs.hgc.jp/). Loci of $200 \mathrm{bp}$ upstream of the first gene in the operons were searched for transcriptional factor (TF) binding sites by the DBTBS tools.

Co-regulation of genes at different conditions was estimated as four folds phi-correlation (Fleiss et al., 2013):

$$
\varphi=\frac{n_{11} n_{22}-n_{12} n_{21}}{\sqrt{\left(n_{11}+n_{21}\right)\left(n_{12}+n_{22}\right)\left(n_{11}+n_{12}\right)\left(n_{21}+n_{22}\right)}}
$$


where $n_{11}$ - number of genes activated at both conditions; $n_{12}$ - number of genes activated at the first condition, but repressed at the second condition; $n_{21}$ - number of genes repressed at the first condition, but activated at the second condition; and $n_{11}$ - number of genes repressed at both conditions.

The whole genome regulation network was constructed and visualized using Cytoscape 3.2.1 for Windows (64 bit) (http://www.cytoscape.org/cy3.html). Metabolic pathways for regulated genes were identified using the Pathway Tools software version 13.0 for 64-bit Windows 7 (Karp et al., 2010).

\subsection{Identification of differentially expressed non-coding RNA}

Non-coding RNA (ncRNA) loci were identified by differential density of Illumina reads aligned against the intergenic spacer regions of the genome of B. atrophaeus UCMB-5137. They were considered as regulated by the root exudates, if their level of differential transcription exceeded the 3 folds threshold with at least 50 reads mapped to the region in the sample with the highest expression. To avoid false-positive identification of untranslated regions (5'-UTR) as ncRNA, only the loci flanked by oppositely regulated genes were considered in this work. Identified sequences were compared to the records of ncRNA in SubtiWiki database (Michna et al., 2015) and those reported by Fan et al. (2015) in Bacillus amyloliquefaciens FZB42. The level of sequence conservation of predicted ncRNA was checked by BLASTN search through the complete genome DNA sequences of B. subtilis ssp. subtilis 168 (NC_000964), B. amyloliquefaciens ssp. plantarum FZB42 (NC_009725), B. licheniformis ATCC 14580 (NC_006270), B. pumilus SAFR-032 (NC_009848), B. halodurans C-12 (NC_002570) and B. cereus ATCC 14579 (NC_004722). If the conserved regions were found at least in 3 different genomes, possible mRNA targets for predicted ncRNA then were identified by using CopraRNA (Wright et al., 2014). Predictions of the target mRNA with $\mathrm{p}$-value of $\leq 1 \times 10^{-5}$ were considered reliable.

\section{Results and Discussion}

\subsection{Complete genome sequence of the strain UCMB-5137 and its phylogeny} In total, 2,233,142 paired-end Illumina MiSeq reads were generated from the RNA samples obtained from two bacterial cultures treated with the root exudates and 5,555,122 reads were obtained from the untreated cultures. The previously published complete genome sequence of B. atrophaeus UCMB-5137 (Chan et al., 2013) was updated by closing the gaps with the newly generated reads. A new version of the genome was deposited in the GenBank database under the accession number CP011802 (RefSeq NZ_CP011802.1, NCBI ASM38596v2).

BLASTP search through the sequences of genomes of 22 other publicly available microorganisms belonging to the B. subtilis group revealed 3,025 clusters of orthologous protein coding genes. To clarify the phylogenetic position of the strain UCMB-5137 within the B. subtilis taxonomic group, a super-alignment of all orthologous genes was analyzed by the Neighbor-Joining algorithm implemented in MEGA 6.0. The phylogenetic position of the strain UCMB-5137 is shown in Fig. 1. The strain UCMB-5137 was grouped together with the reference strain of Bacillus atrophaeus. However, it was separated from the cluster of other multiple sequenced strains of this species. It was hypothesized that UCMB-5137 might represent a sub-species of B. atrophaeus but this hypothesis was not further analyzed in this study. 


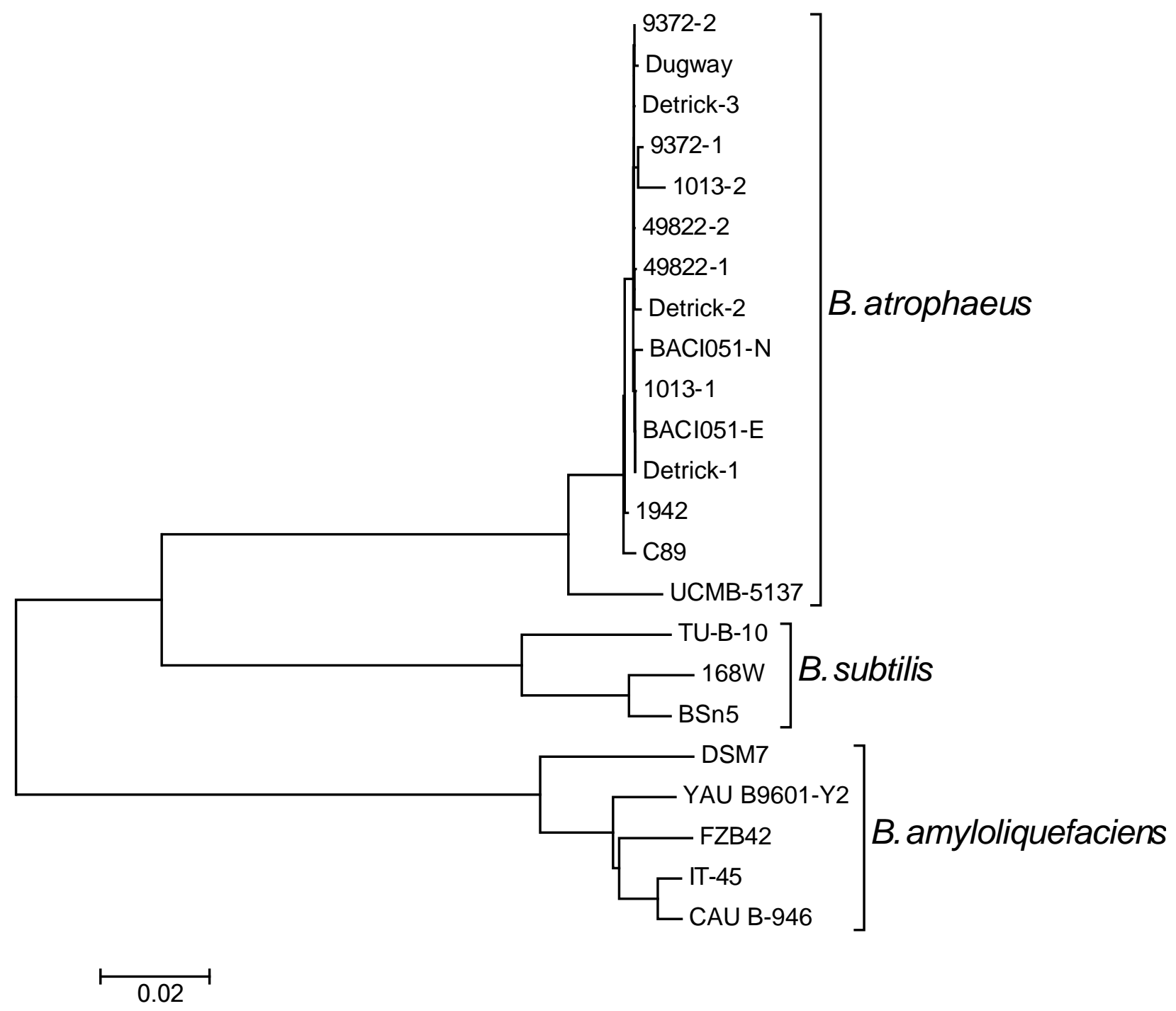

Fig. 1. Neighbor-joining species tree constructed for the selected organisms of the B. subtilis group based on concatenated alignments of amino acid sequences of orthologous proteins.

\subsection{Gene expression profiling}

Up- and down-regulated genes in samples treated by the root exudates compared to the control samples were determined with the fold difference exceeding the factor of 3 and $p$-value $\leq 0.05$. The detected genes were grouped by their functional associations (supplementary Table S1). A ratio of 54 up-regulated versus 152 down-regulated genes was observed in the total set of samples. Particularly: amino acid, nucleotide, carbohydrate and fatty acid biosynthetic pathways, anaerobic respiration pathway and also the associated $\mathrm{ABC}$-transport systems were mainly down-regulated by the root exudates. It was also true for all genes associated with identified prophages and horizontally transferred genomic islands. Contrary, several genes for cell surface protein biosynthesis and posttranslational processing, aerobic respiration genes and also multiple transcriptional regulators were stimulated by the root exudates. Genes involved in DNA replication and cell division processes were mostly up-regulated by the root 
exudates that. However, the bacteria treated with the root exudates did not show any increase in the rate of growth. More details on metabolic pathway regulation may be found in Table S1.

Many of the genes activated by the root exudates were associated with the stress response and detoxification. Activation of the GABA shunt and spermidine biosynthesis indicated a preparation to oxidative and/or acidic stresses (Feehily \& Karatzas, 2013). Activation of the stress response genes in PGPR organisms by the root exudates was reported in a previous study (Matilla et al., 2007). Through the observed up-regulation of the SasA alarmone biosynthesis pathway it was hypothesized that the level of (p)ppGpp might be increased in bacteria treated with the root exudates. The alarmone (p)ppGpp could trigger a stringent response in bacteria experiencing nutrient exhaustion. No signs of the stringent response were observed at the control conditions when the medium was the same but without the root exudates. We therefore concluded that there should be no real nutrient exhaustion in the medium. According to Braeken et al. (2006), (p)ppGpp alarmone was also involved in many physiological processes including adaptation to changed environmental conditions and interactions between bacteria and eukaryotic cells.

Aligning of the DNA reads against non-coding intergenic loci of the complete genome sequence of B. atrophaeus UCMB-5137 showed multiple differently expressed regions, which could not be translated to any putative proteins. A search for differentially regulated intergenic spacer regions revealed at least 49 loci of putative ncRNA. Genomic location of the identified ncRNA, their neighboring genes, possible mRNA targets and known ncRNA orthologs are listed in Table 1. Out of these 49 ncRNA loci, 40 were up-regulated by the root exudates. There were many other down-regulated intergenic spacer loci; however, since it was difficult to distinguish them from putative 5'-UTR as they were surrounded by down-regulated neighbor genes, these loci were not considered in this study.

Table 1. Non-coding loci regulated by the root exudates. Locations of loci are given as in CP011802.

\begin{tabular}{|c|c|c|c|c|c|}
\hline Name & Location & Upstream gene & $\begin{array}{l}\text { Fold } \\
\text { change }\end{array}$ & Predicted targets & Orthologs* \\
\hline ncr20 & $22230 . .22278$ & D068_03770 & 19.94 & $\begin{array}{l}\text { YllB MraZ protein; } \\
\text { SpoIVB peptidase; }\end{array}$ & \\
\hline ncr23 & $25176 . .25569$ & D068_03810 & 3.96 & No conservation; & \\
\hline ncr28 & $28250 . .28322$ & D068_03850 & 3.1 & $\begin{array}{l}\text { NagP component of PTS } \\
\text { system; }\end{array}$ & \\
\hline ncr63 & $67120 . .67569$ & D068_04240 & 5.99 & No conservation; & \\
\hline ncr86 & $95107 . .95160$ & D068_04490 & 3.29 & No conservation; & $b s r F$ \\
\hline ncr299 & $4000114 . .4000377$ & D068_19000 & 15.39 & PucD xanthine dehydrogenase; & $\begin{array}{l}\text { scr small cytoplasmic } \\
\text { scRNA }\end{array}$ \\
\hline ncr409 & 377769..378299 & D068_07850 & 3.35 & No conservation; & \\
\hline ncr628 & $599457 . .599519$ & D068_09620 & -inf & $\begin{array}{l}\text { Downstream gene: CueR } \\
\text { transcriptional regulator; }\end{array}$ & \\
\hline ncr818 & $777740 . .777830$ & D068_11560 & -2.44 & $\begin{array}{l}\text { Downstream gene: tryptophan- } \\
\text { tRNA ligase TrpS; }\end{array}$ & $\operatorname{trpS-oppA,~bar094}$ \\
\hline ncr912 & $853200 . .853261$ & D068_12600 & 4.27 & $\begin{array}{l}\text { YlbQ 2-dehydropantoate } \\
\text { reductase; } \\
\text { YeaB transporter; }\end{array}$ & \\
\hline
\end{tabular}




\begin{tabular}{|c|c|c|c|c|c|}
\hline ncr1014 & $939698 . .939779$ & D068_13670 & 5.6 & $\begin{array}{l}\text { YkrV, MtnE transaminase; } \\
\text { CotE spore coat protein; }\end{array}$ & \\
\hline ncr1068 & $997865 . .998060$ & D068_14210 & -inf & No conservation; & \\
\hline ncr1092 & $1020314 . .1020360$ & D068_14450 & -47.94 & $\begin{array}{l}\text { SpoIVB peptidase; } \\
\text { YqjI 6-phosphogluconate } \\
\text { dehydrogenase; }\end{array}$ & $y k w D-p b p H$ \\
\hline ncr1258 & 1108507..1180808 & D068_16150 & 3.03 & No significant match found; & \\
\hline ncr1305 & $1226294 . .1226547$ & D068_16630 & 12.04 & $\begin{array}{l}\text { NatB sodium efflux ABC } \\
\text { transporter permease; } \\
\text { RpoA DNA-directed RNA } \\
\text { polymerase; }\end{array}$ & \\
\hline ncr1509 & $1477643 . .1478293$ & D068_18730 & 4.1 & No conservation; & \\
\hline ncr1648 & $1625065 . .1625385$ & D068_20480 & 3.06 & No conservation; & \\
\hline ncr1827 & $1821647 . .1822003$ & D068_22450 & 14.59 & $\begin{array}{l}\text { YfhS and YgzB hypothetical } \\
\text { proteins; }\end{array}$ & \\
\hline ncr1829 & $1823159 . .1823313$ & D068_22470 & 7.92 & $\begin{array}{l}\text { YlIB MraZ protein; } \\
\text { YetA hypothetical protein; } \\
\text { YesN transcriptional regulator; } \\
\text { SpoIVB peptidase; }\end{array}$ & \\
\hline ncr1891 & $1877568 . .1877676$ & D068_23110 & 3.44 & $\begin{array}{l}\text { MiaA tRNA } \\
\text { dimethylallyltransferase; }\end{array}$ & \\
\hline ncr1947 & 1925995..1926105 & D068_23670 & 5.55 & No conservation; & \\
\hline ncr2198 & $2143072 . .2143195$ & D068_26260 & 3.4 & $\begin{array}{l}\text { Downstream gene: YqeG } \\
\text { hypothetical protein; } \\
\text { YIIB MraZ protein; } \\
\text { SpoIVB peptidase }\end{array}$ & \\
\hline ncr2239 & $2178179 . .2178362$ & D068_01700 & 3.29 & CotE spore coat protein; & $g \operatorname{lm} M-g \operatorname{lm} S$ \\
\hline ncr2499 & $2463009 . .2463121$ & D068_31760 & 22.34 & No significant match found; & $b s r C$ \\
\hline ncr2755 & $2697733 . .2697777$ & D068_29190 & -inf & AhpF NADH dehydrogenase; & bar067 \\
\hline ncr2792 & $2734908 . .2735126$ & D068_28810 & 4.2 & YqgL hypothetical protein; & \\
\hline ncr2833 & $2779026 . .2779093$ & D068_28380 & 12.28 & $\begin{array}{l}\text { RpsD 30S ribosomal protein } \mathrm{S} 4 \\
\text { NhaX stress response protein; }\end{array}$ & $\operatorname{trxA-xsa}$ \\
\hline ncr2852 & $2795834 . .2795898$ & D068_28200 & -inf & No conservation; & \\
\hline ncr2853 & $2796437 . .2796600$ & D068_28190 & 3.59 & $\begin{array}{l}\text { YdiK lipoprotein; } \\
\text { TcyP L-cystine uptake protein; }\end{array}$ & \\
\hline ncr2893 & $2839504 . .2839767$ & D068_27790 & 6.14 & No significant match found; & \\
\hline ncr3022 & $2955963 . .2956313$ & D068_26460 & 3.42 & No conservation; & \\
\hline ncr3198 & $3034438 . .3034536$ & D068_33310 & 3.61 & $\begin{array}{l}\text { Downstream gene: DegQ } \\
\text { transcriptional regulator; }\end{array}$ & \\
\hline ncr3267 & $3105503 . .3105823$ & D068_34020 & 3.85 & No conservation; & \\
\hline ncr3314 & $3150551 . .3150665$ & D068_34530 & 5.04 & No significant match found; & \\
\hline ncr3409 & $3244049 . .3244404$ & D068_35490 & 15.74 & YjlA possible transporter; & ssrA tmRNA \\
\hline ncr3458 & $3290801 . .3290900$ & D068_36020 & 3.56 & $\begin{array}{l}\text { RpsG 30S ribosomal protein S7; } \\
\text { YkoQ } \\
\text { metallophosphoesterase; } \\
\text { YqjP and YtnM hypothetical }\end{array}$ & \\
\hline
\end{tabular}




\begin{tabular}{|c|c|c|c|c|c|}
\hline & & & & proteins; & \\
\hline ncr3519 & $3349197 . .3349330$ & D068_36640 & 2.37 & $\begin{array}{l}\text { Downstream gene: YvcI Nudix } \\
\text { hydrolase; } \\
\text { TenA thiaminase; }\end{array}$ & $y v c I-\operatorname{trx} B$ \\
\hline ncr3522 & $3351953 . .3352333$ & D068_36670 & 7.75 & No conservation; & \\
\hline ncr3526 & $3356453 \ldots 3356663$ & D068_36720 & 3.46 & No conservation; & \\
\hline ncr3628 & $3460797 . .3460941$ & D068_37800 & -inf & No conservation; & \\
\hline ncr3736 & $3555042 . .3555497$ & D068_38890 & -8.92 & No conservation; & bar073 \\
\hline ncr3772 & $3583861 . .3583995$ & D068_39260 & 2.03 & GpsB cell cycle protein; & bar096 \\
\hline ncr3826 & $3637975 . .3638305$ & D068_39820 & 3.52 & No conservation; & \\
\hline ncr3877 & $3685045 . .3685132$ & D068_40350 & 4.2 & $\begin{array}{l}\text { Downstream gene: QoxA quinol } \\
\text { oxidase subunit; }\end{array}$ & \\
\hline ncr3952 & $3752185 . .3752625$ & D068_41140 & 3.03 & No conservation; & \\
\hline ncr 4000 & $3793213 . .3793326$ & D068_41680 & -inf & $\begin{array}{l}\text { CysB cyclodextrin-binding } \\
\text { protein; }\end{array}$ & bar084 \\
\hline ncr4136 & $3931507 . .3931653$ & D068_43080 & 3.42 & YIIB MraZ protein; & \\
\hline ncr4157 & $3956921 . .3957068$ & D068_43320 & 3.57 & $\begin{array}{l}\text { RapC aspartate phosphatase } \mathrm{C} \\
\text { response regulator and } 10 \text { other } \\
\text { paralog genes; }\end{array}$ & \\
\hline ncr4176 & $3973567 . .3973915$ & D068_43510 & 6.56 & $\begin{array}{l}\text { XhlA phage-like protein; } \\
\text { YllB MraZ protein; }\end{array}$ & \\
\hline
\end{tabular}

*Orthologous ncRNA were searched by sequence similarity among sequences of ncRNA found in B. amyloliquefaciens FZB42 (Fan et al., 2015) and indicated as barO\#\#, and in SubtiWiki database. In the later database ncRNA found in B. subtilis 168 were presented either by names, or by names of flanking genes: $\operatorname{trpS}$-oppA for example.

\subsection{Superimposition of the gene regulation profile in $B$. atrophaeus over the regulatory network of $B$, subtilis}

B. atrophaeus is the closest relative of B. subtilis. The gene regulation network was studied in B. subtilis by many researches and summarized in SubtiWiki (Michna et al., 2015) and DBTBS databases (Sierro et al., 2008). Both species belonged to the same group of related organisms, which were not easily distinguished even by the 16S rRNA sequences (Safronova et al., 2012). We concluded that the transcription regulatory network known for B. subtilis might be fully applied to study the regulation of the orthologous genes in B. atrophaeus. Supplementary Table S1 presented known activators and repressors associated with the regulated genes. A visualization of the superimposition of the gene regulations in UCMB-5137 under the root exudate stimuli over the regulatory network of B. subtilis was shown in Fig. 2. Clusters of co-regulated genes in Fig. 2 were titled by the corresponding TFs or sigma-factors. Inconsistence in regulation of the protein coding genes and the corresponding TFs was depicted by red edges linking the nodes of the genes and TFs. For example, if a gene encoding a transcriptional activator was up- or downregulated, it was expected that all the genes dependent on this activator would be regulated accordingly. On the contrary, regulation of a repressor should cause an opposite regulation of all the related genes. If a gene was regulated by several TFs, this regulation was accepted as consistent if there was consistency in the regulation at list with one TF. Contradictions depicted in Fig. 2 might indicate shortage of our knowledge on TFs involved in the gene regulation at the given condition. 


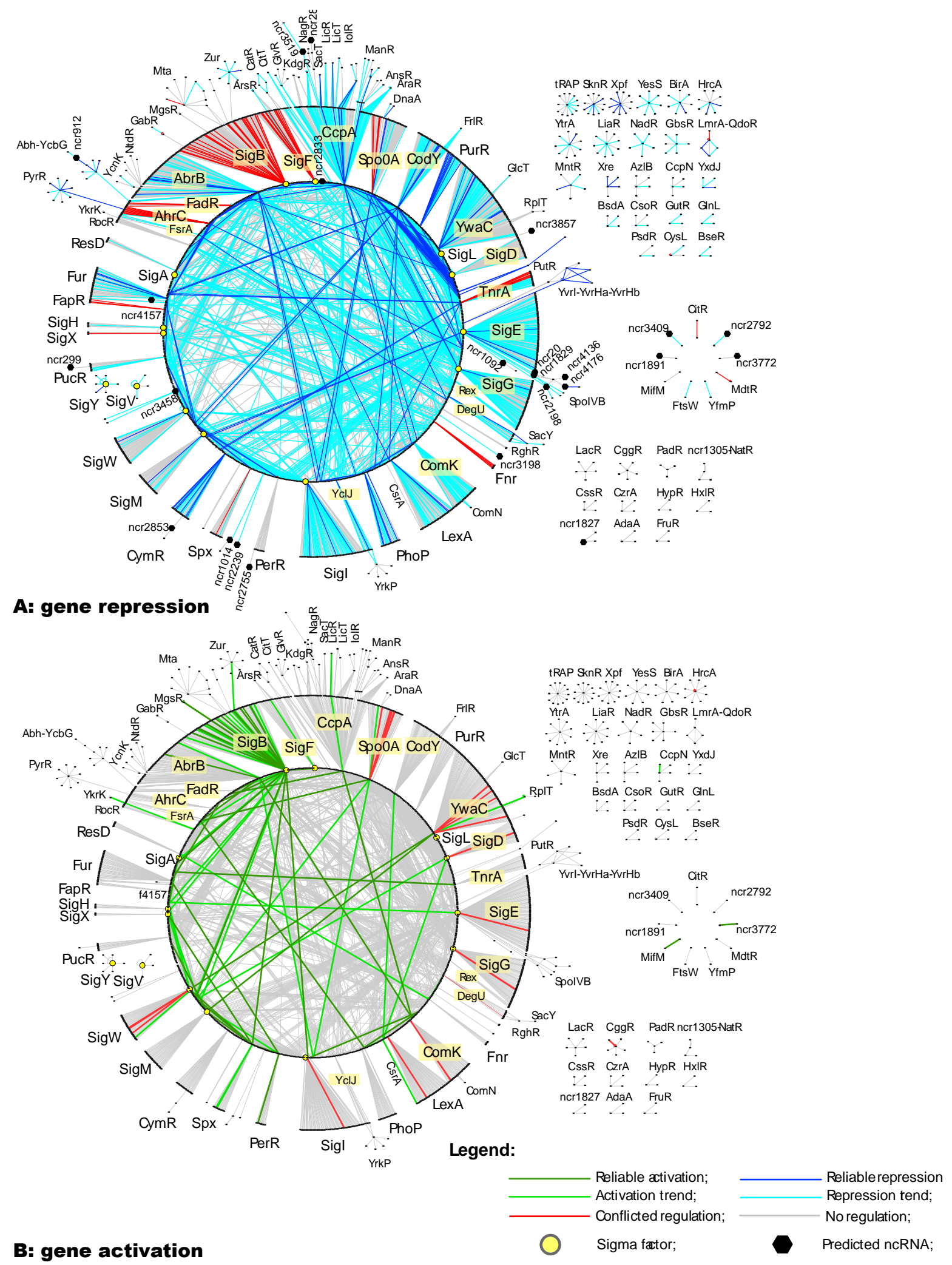

Fig. 2. Regulatory network constructed based on the regulon predictions for B. subtilis 168 as presented in SubtiWiki database. Repressions and activations of the genes in UCMB-5137 were superimposed over the regulatory network in parts A and B, respectively. 
The biggest number of the conflicted gene repressions was observed among the genes regulated by $\mathrm{SigB}$ (stressosome), SigF (sporulation regulon), AhrC (arginine metabolism regulon), FadR (fatty acid degradation regulon), FapR (fatty acid biosynthesis regulon), Fnr (anaerobiosis and overflow metabolism) and TnrA (nitrogen assimilation). Conflicted gene activations were observed in YwaC (ppGpp associated regulon independent from stringent response) and SigW (resistance and detoxification) regulons. The majority of the genes controlled by the upregulated Spo0A (sporulation initiation) were activated or repressed oppositely to what might be expected. It was supposed that all these genes were additionally controlled either by other TFs, or Spo0A was somehow inactivated by other regulatory factors triggered by the treatment with the root exudates. An interference of the regulatory ncRNA molecules in this process was assumed.

Many general stress response genes were up-regulated by the root exudates, especially those controlled by the SigB stressosome (Fig. 2A). To identify specific regulations not associated with the general stress response, the pattern of gene regulation observed in the current study was compared to the stress response patterns reported earlier (Sappa 2013; Kohlstedt et al., 2014). Significant correlation was observed between the gene regulation patterns triggered by the root exudates and those under nutrient stringency and high temperature stresses, while the congruence with the low temperature growth and osmotic stress conditions was lower. It might be explained in a way that the nutrient stringency, higher temperature growth and plant root colonization were all associated with an increased oxidative stress resulted from accumulation of free radicals (Lamb \& Dixon, 1997). Majority of the genes activated at the stress conditions and in the current experiment were controlled by SigB and partly by SigW (Table 2). Down-regulations of gene expression at all these conditions was controlled by CodY and several other repressors. The genes regulated oppositely to the patterns of the general stress response were of interest for us as they most likely were associated with the specific response of $B$. atrophaeus UCMB-5137 to the root exudate stimuli. In total, 250 operons were identified comprising 426 protein coding genes. All these genes were controlled by multiple TFs and sigma-factors (Table 2), particularly by AbrB and Abh (transition to stationary phase), PerR (peroxide response), CggR (glycolysis activator) and WalR (synthesis of cell wall proteins). However, regulation of many of these genes in Bacillus was

Table 2. Co-regulation of gene expression by the root exudates and different stress conditions.

\begin{tabular}{|c|c|c|c|c|c|}
\hline \multirow{2}{*}{$\begin{array}{l}\text { Stress conditions } \\
\text { Root exudate }\end{array}$} & \multicolumn{2}{|c|}{ Up-regulated genes } & \multicolumn{2}{|c|}{ Down-regulated } & \multirow{2}{*}{$\begin{array}{l}\text { Pearson } \\
\text { correlation } \\
\text { coefficient }\end{array}$} \\
\hline & Up-regulated & Down-regulated & Up-regulated & Down-regulated & \\
\hline Stationary growth & 25 & 23 & 5 & 64 & 0.505 \\
\hline Growth at $51^{\circ} \mathrm{C}$ & 11 & 24 & 0 & 26 & 0.404 \\
\hline Growth at $16^{\circ} \mathrm{C}$ & 20 & 20 & 8 & 27 & 0.280 \\
\hline Growth with $1.2 \mathrm{M} \mathrm{NaCl}$ & 3 & 11 & 4 & 20 & 0.059 \\
\hline Regulatory TFs & SigB, SigW & $\begin{array}{c}\text { PutR, CodY, AbrB, } \\
\text { SigE, SifF, SpoIIID, } \\
\text { ScoC, TnrA, Fur, } \\
\text { Spo0A }\end{array}$ & $\begin{array}{c}\text { SigD, SinR, SigB, } \\
\text { CggR, ResD, Fnr, } \\
\text { NsrR, Spo0A }\end{array}$ & $\begin{array}{c}\text { CodY, SigD, SigK, } \\
\text { SigW, AbrB, CcpA, } \\
\text { TnrA, KipR, FapR, } \\
\text { MntR , Spo0A }\end{array}$ & \\
\hline
\end{tabular}




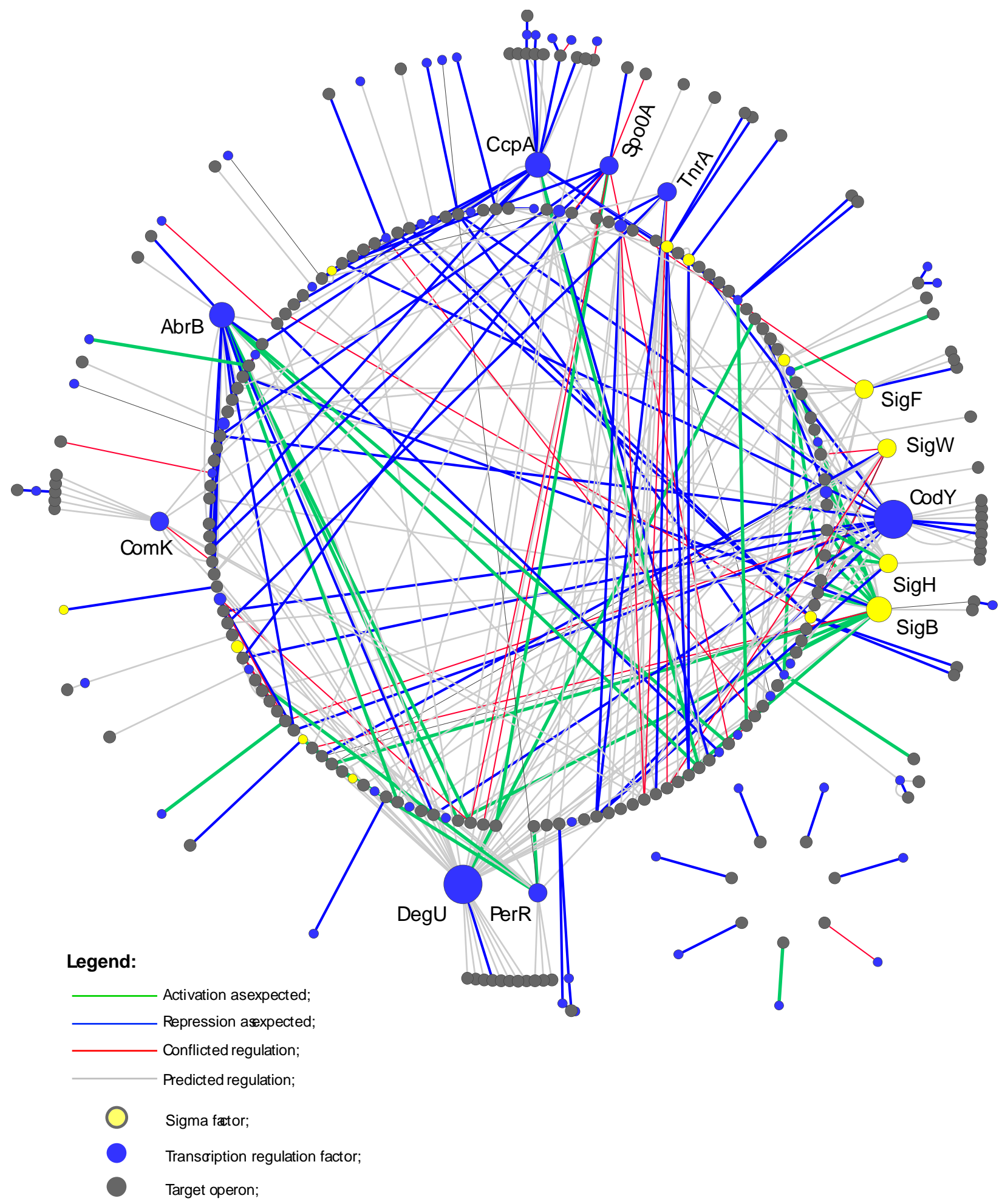

Fig. 3. Regulatory network of the genes, which regulation by the root exudates was incongruent to the general stress response regulation. The nodes representing transcriptional factors were sized according to the numbers of regulated genes. Labeled TFs were involved in regulation of at least 5 protein coding genes. 
obscured. Search for possible TF binding sites in 200 bp flanking regions up-stream to the operon start codons was performed. Identified TFs are listed in supplementary Table S2. A combined overview of known and predicted TFs involved in regulation of these operons is shown in Fig. 3. The major repressors activated by the root exudate stimuli were CcpA (mediated carbon catabolite repressor), CodY (pleiotropic repressor), TnrA (nitrogen assimilation regulator) and Spo0A. However, the role of the latter regulator should be taken cautiously as at the treatment condition the effect of Spo0A most likely was modulated by other unknown transcriptional factors (see Fig. 2 and the discussion above). The major activators were $\mathrm{AbrB}$ and $\mathrm{SigH}$ (both regulated the transition to stationary phase and the cell growth rate), SigB and PerR (general stress and oxidative stress response, respectively).

Fig. 3 highlighted a possible crucial role of DegU in regulation of the plant root colonization by Bacillus. The DegU binding sites were identified in front of almost all regulated operons; however, only some of them were reported in the literature as parts of the DegU regulon. It is known that DegU in B. subtilis is an important regulator of many processes including chemotaxis, motility, extracellular secretion, quorum sensing and biofilm formation (Msadek et al., 1991; Murray et al., 2009; Gupta \& Rao, 2014; Omer et al., 2015). It was reported that inactivation of DegU in B. amyloliquefaciens FZB42 led to impairing in efficient root colonization (Budiharjo et al., 2014). Finding of DegU binding sites in front of the operons specifically regulated by the root exudates confirmed the importance of this TF for plant colonization behavior.

\subsection{Role of ncRNA in gene regulation under root exudate stimuli}

It was known that many TFs were controlled by ncRNA. For example, it was reported for AhrC regulator (Brantl \& Brückner, 2014). Conflicted regulation of the genes controlled by AhrC was observed in this study. Also, conflicts were observed in the regulation of genes controlled by SigB, SigW, SigF, YwaC, Spo0A, FadR and several other TFs (Fig. 2).

The majority of ncRNA identified so far in B. subtilis were antisense translational inhibitors including dual-function genes encoding both regulatory RNA and small regulatory proteins. One example of the dual-function genes was SR1 (Brantl \& Brückner, 2014). In B. atrophaeus UCMB-5137, SR1 corresponded to the predicted protein coding gene D068_15140, which was not regulated by the root exudates. Two other genes D068_34490 and D068_15550 predicted in UCMB-5137 as small unknown proteins had shared sequence similarities with bsrI and csfG regulatory RNA of B. subtilis, respectively. These genes were repressed by the root exudates. Multiple cis-encoded phage related antitoxins were repressed by the root exudates together with all the phage related genes.

Many ncRNA predicted in this study had showed significant sequence conservation in different species of Bacillus despite being located in variable intergenic spacer regions. This conservation allowed prediction of possible target mRNA by using CopraRNA Web-service (Table 1). Contributions of the found ncRNA to the gene regulatory network of B. atrophaeus UCMB-5137 were summarized in Fig. 2A. Six predicted ncRNA, - ncr628, ncr818, ncr2198, ncr3198, ncr3519 and ncr3877, - were located near the promoter regions of the genes, which were their most likely targets. Other six ncRNA, - ncr20, ncr628, ncr1092, ncr1829, ncr2198 and ncr3198, - aimed at different transcriptional regulators. Particularly, the genes of the SpoIVB regulon including $m r a Z$, which was reported in 
several studies as a new TF inhibiting the cell division (Meile et al., 2006; Eraso et al., 2014), most likely were under control of the predicted ncRNA (Fig. 2A).

Among other potential targets of the predicted ncRNA, there were several genes, which have not been associated with any TF regulons in SubtiWiki. In Table 1, these genes were depicted by the bold typeface. In general, ncRNA were considered in the literature as translational inhibitors. However, several ncRNA were reported to be able to prolong the lifetime of mRNA (Wagner \& Romby, 2015). It may explain the observed differences in RNA abundance of several genes, which presumably were controlled in B. atrophaeus UCMB-5137 exclusively by ncRNA under the root exudate stimuli.

\subsection{Comparison of the gene expression profiles of B. atrophaeus UCMB-5137 and $B$, amyloliquefaciens FZB42 stimulated by the root exudates}

It was interesting to study to which extent the gene regulation by the root exudate stimuli in B. atrophaeus UCMB5137 was congruent to that reported previously for the paradigm PGPR B. amyloliquefaciens FZB42. The gene expression profile of B. atrophaeus UCMB-5137 from the current research was compared to the microarray and proteomics profiles of B. amyloliquefaciens FZB42 published earlier (Fan et al., 2012; Kierul et al., 2015). The transcriptional profiles appeared to be substantially different (Table 3). For example, the chemotaxis and motility genes were down regulated in B. atrophaeus (see also the supplementary Table S1) in contrast to what was reported for B. amyloliquefaciens. All the mentioned genes were under control of $\mathrm{SigD}$, which was two folds downregulation by the root exudates in the current experiment. While $\mathrm{SigD}$ was down-regulated, its repressor CodY was two folds up-regulated by the root exudates in B. atrophaeus UCMB-5137. From the literature it is known that the sporulation repressor CodY is activated in Bacillus by the catabolic repressor CcpA (Ratnayake-Lecamwasam et al., 2001). It implied a possible role of CcpA in gene regulation by the root exudates.

The similarity between B. atrophaeus UCMB-5137 and B. amyloliquefaciens FZB42 was in activation of the genes $y m c A$ and luxS controlling biofilm formation (Nicolas et al., 2012). It is known that luxS is also an activator of synthesis of the quorum sensing autoinducer AI-2 (Ruzheinikov et al., 2001). Activation of $y l b F$, which is an antagonist of the biofilm repressor SinR (Kearns et al., 2005), was also observed in B. atrophaeus UCMB-5137 treated by the root exudates. FlaA flagella protein synthesis was activated by the root exudates in both organisms. It was reported in a study on Bacillus cereus that FlaA was important for biofilm formation and had nothing to do with other flagellin proteins (Houry et al., 2010), which were down-regulated by the root exudates in B. atrophaeus UCMB-5137. These observations confirmed the activation of the quorum sensing triggered biofilm formation in B. atrophaeus UCMB-5137 and B. amyloliquefaciens FZB42 in response to the root exudate stimuli.

The most striking and unexpected effect on gene expression in B. atrophaeus UCMB-5137 treated by the root exudates was the strong stringent response presumably triggered by the alarmone (p)ppGpp. Summarized scheme of interactions between the key TFs and the regulated genes is shown in Fig. 4. Similarities in the responses to the treatment with root exudates in B. atrophaeus UCMB-5137 and B. amyloliquefaciens FZB42 were represented on the right part of the Fig. 4, and the dissimilar regulations were shown on the left part of the figure. The stringent response and general catabolic repression by CcpA could explain all the differences between the expression profiles of these two microorganisms. The stringent response was known to be accompanied by the general stress response 
Table 3. Comparison of the gene expression profiles observed in B. atrophaeus UCMB-5137 and reported for B. amyloliquefaciens FZB42.

\begin{tabular}{|c|c|c|c|}
\hline \multirow[t]{2}{*}{ Genes, pathway and/or metabolic processes } & \multirow{2}{*}{$\begin{array}{c}\text { UCMB-5137 } \\
\text { RNA-Seq (this work) }\end{array}$} & \multicolumn{2}{|c|}{ FZB42 } \\
\hline & & $\begin{array}{l}\text { Microarray hybridization } \\
\text { data (Fan et al., 2012) }\end{array}$ & $\begin{array}{l}\text { Proteomics data (Kierul et } \\
\text { al., 2015) }\end{array}$ \\
\hline \multicolumn{4}{|c|}{ Similar response to root exudate in both organisms } \\
\hline Biofilm and quorum sensing: $y m c A$ and $l u x S$ genes. & Up-regulated & Up-regulated & Not reported \\
\hline $\begin{array}{l}\text { Proteins secreted in late exponential phase: SodA } \\
\text { (superoxide dismutase), Tpx (thiol peroxidase), }\end{array}$ & Up-regulated & Not reported & Up-regulated \\
\hline \multicolumn{4}{|l|}{ AhpC (alkyl hydroperoxide reductases C), YodJ (D- } \\
\hline \multicolumn{4}{|l|}{ Alanine carboxypeptidase), CysK (cysteine synthase } \\
\hline \multicolumn{4}{|l|}{ A) and $\mathrm{FbaA}$ (fructose 1,6-bisphosphate hydrolase) } \\
\hline PenP (beta-lactamase precursor) & Down-regulated & Not reported & Down-regulated \\
\hline All phage-associated genes & Down-regulated & Not reported & $\begin{array}{l}\text { Down-regulated } \\
\text { (associated with the late } \\
\text { exponential phase) }\end{array}$ \\
\hline Cold shock protein CspA & Up-regulated & Not reported & Up-regulated \\
\hline \multicolumn{4}{|l|}{ Dissimilar response to root exudate } \\
\hline Genes involved in carbon and nitrogen utilization & Down-regulated & Up-regulated & Not reported \\
\hline Genes involved in mobility and chemotaxis & Down-regulated & Up-regulated & Not reported \\
\hline $\begin{array}{l}\text { Non-ribosomal synthesis of secondary metabolites } \\
\text { with antimicrobial action such as surfactin } \\
\text { synthetase }\end{array}$ & Down-regulated & Up-regulated & Up-regulated \\
\hline Inositol metabolism IolFGEDBC & Down-regulated & Up-regulated & Not reported \\
\hline $\begin{array}{l}\text { Lipids metabolism: FabI enoyl-(acyl-carrier-protein) } \\
\text { reductase and FabF acyl carrier protein synthase II }\end{array}$ & Down-regulated & Not reported & Up-regulated \\
\hline ChbA chitin-binding protein & Down-regulated & Not reported & Up-regulated \\
\hline Tricarboxylic acid (TCA) cycle & $\begin{array}{l}\text { Differentially regulated } \\
\text { but below statistical } \\
\text { reliability }\end{array}$ & Up-regulated & Not reported \\
\hline Oligopeptide ABC transportes OppADF & $\begin{array}{l}\text { Down-regulated } \\
(\mathrm{p}>0.05)\end{array}$ & Up-regulated & Not reported \\
\hline Phosphotransferase system (PTS) & Down-regulated & Up-regulated & Not reported \\
\hline
\end{tabular}

(Eyman et al., 2002) and by activation of the SigB stressosome that caused up-regulation of many general stress response genes (Hecker et al. 2007). The results of our study were in agreement with the previous publications that reported significant down-regulation of the SigD activator of motility and chemotaxis by different stress conditions (Sappa 2013; Kohlstedt et al., 2014). This effect might be linked to the activation of the CodY repressor, which also repressed the amino acid metabolism and many other metabolic pathways at the time of transition from the exponential to stationary growth phases in response to shortage of nutrients (Serror \& Sonenshein, 1993; Bergara et al., 2003). 


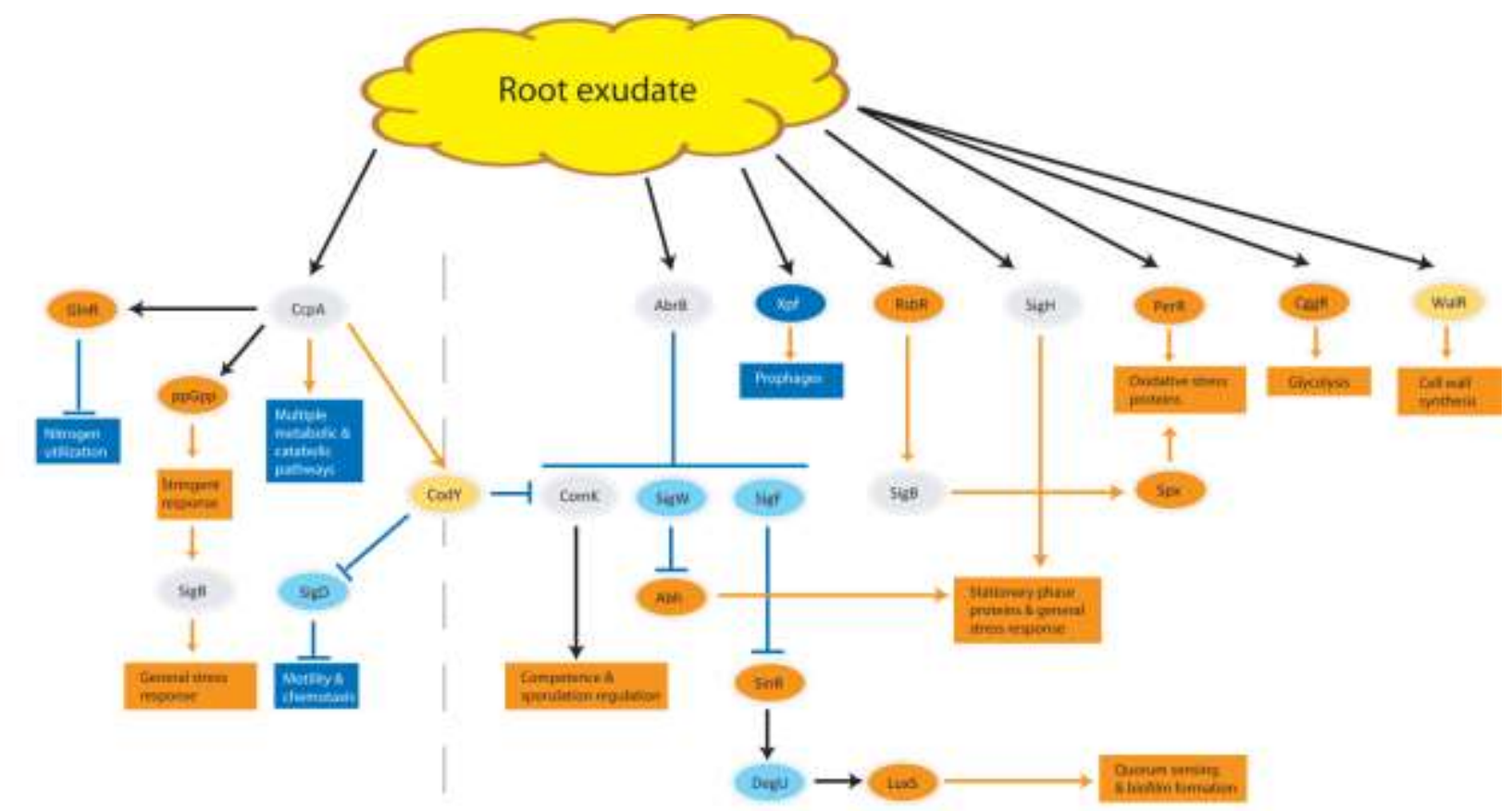

Dissimilar response to root exudate in UCMB-5137 and FZB42

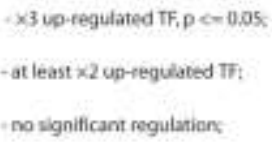

Similar response to root exudate in UCMB-5137 and FZB42

Fig. 4. Schematic representation of involvement of the top level transcriptional factors, which may explain the observed differences and similarities in the gene expression profiles of B. atrophaeus UCMB-5137 and B. amyloliquefaciens FZB42.

It remained unclear which factors could trigger such strong stress on B. atrophaeus UCMB-5137 resulted from an addition to the medium of a tiny amount of the root exudates. It was hypothesized that the stress could be associated with the metabolic repression caused by CcpA. The major function of the CcpA repressor is to optimize the carbon and nitrogen metabolism by repressing the pathways of utilization of less convenient sources of nutrients, when there is an abundance of easily accessible sugars and ammonium (Wacker et al., 2003; Görke \& Stülke, 2008). Normally CcpA is activated by glucose, which is a major component of the root exudates (Fan et al., 2012). However, other components, i.e. organic acids, melibiose and traces of amino acids, might intensify this response. The amount of the root exudates added to the medium could not provide any sufficient increase in the amount of nutrients, but it could mislead the bacteria by signaling the presence of plant roots suitable for colonization in the close vicinity, which could be a source of surplus of plant sugars (Dennis et al., 2010). The strong carbon metabolism repression without any supply of additional sugars could cause an abrupt shortage of energy and nutrients that led to accumulation of uncharged tRNA molecules, which in their turn had triggered the stringent response trough ppGpp alarmone activation (Eymann et al., 2002) and further repression of many metabolic pathways by ppGpp activation of the CodY repressor (Wünsche et al., 2012; Geiger \& Wolz, 2014). 


\section{Conclusion}

The current study showed limitations of our knowledge of the gene regulatory network in B. subtilis and related organisms. The whole dimension of the gene regulations by small non-coding RNA is still to be discovered. Significant alterations in the gene regulation profiles between B. atrophaeus UCMB-5137 and the paradigm PGPR strain B. amyloliquefaciens FZB42 demonstrated that PGPR could use different strategies for plant colonization. It may be important to count for these differences to achieve an optimal performance of the biopesticides and biofertilizers based on PGPR. It was concluded in this work that these differences could be explained by hypersensitivity of UCMB-5137 to the root exudate stimuli impelling it to a sessile root colonization behavior through the CcpA-CodY-AbrB and probably DegU regulations. It was found that the general stress response genes were significantly up-regulated in UCMB-5137 by the root exudates that might result from the repression of catabolism by CcpA activated by chemicals components of root exudates. Regulation of many genes by the root exudates was inconsistent with our knowledge on the gene regulation in B. subtilis. It was demonstrated that ncRNA interfered with the gene expression regulation at the time of rhizosphere colonization.

\section{Competing interests}

The authors declare that they have no competing interests.

\section{Author contributions}

LM and WYC performed the experiment; ONR and SLL designed the experiment and analyzed the data; TP worked with plants; SVL and LVA worked with the bacterial culture; LM and ONR wrote the manuscript. All authors read and approved the manuscript.

\section{Acknowledgements}

We acknowledge Prof. S.N. Venter and Prof. N. Labuschagne from the Department of Microbiology and Plant Pathology at the University of Pretoria for consultations and providing facilities for the experiments on the current project. Also we are thankful to Prof. R. Borriss from ABiTEP (Germany) for consultations on the experimental design. This study was funded by the PhD fellowship grant provided by the Southern African Biochemistry and Informatics for Natural Products (SABINA, www.sabina-africa.org/), and the National Research Foundation of South Africa (NRF) grants 73983, 86941 and 93664 for travels and collaboration. Sequencing was funded by the Genomics Research Institute (GRI) at the University of Pretoria.

\section{References}

Aziz RK, Bartels D, Best AA, DeJongh M, Disz T, Edwards RA, Formsma K, Gerdes S, Glass EM, Kubal M, Meyer F, Olsen GJ, Olson R, Osterman AL, Overbeek RA, McNeil LK, Paarmann D, Paczian T, Parrello B, Pusch GD, Reich C, Stevens R, Vassieva O, Vonstein V, Wilke A, Zagnitko O (2008) The RAST Server: rapid annotations using subsystems technology. BMC Genomics 9:75.

Bezuidt O, Lima-Mendez G, Reva ON (2009) SEQWord Gene Island Sniffer: a program to study the lateral genetic exchange among bacteria. World Academy of Science, Engineering and Technology 58:1169-1174.

Bashan Y, de-Bashan LE (2005) Plant growth-promoting In Encyclopedia of soils in the environment. In: Hillel D (ed) Elsevier, Oxford, UK Vol 1, pp 103-115. 
Bergara F, Ibarra C, Iwamasa J, Patarroyo JC, Aguilera R, Márquez-Magaña LM (2003) CodY is a nutritional repressor of flagellar gene expression in Bacillus subtilis. J Bacteriol 185:3118-3126.

Blom J, Albaum SP, Doppmeier D, Pühler A, Vorhölter FJ, Zakrzewski M, Goesmann A (2009) EDGAR: a software framework for the comparative analysis of prokaryotic genomes. BMC Bioinformatics 10:154.

Braeken K, Moris M, Daniels R, Vanderleyden J, Michiels J (2006) New horizons for (p)ppGpp in bacterial and plant physiology. Trends Microbiol 14:45-54.

Brantl S, Brückner R (2014) Small regulatory RNAs from low-GC Gram-positive bacteria. RNA Biol 11:443-456.

Broeckling CD, Broz AK, Bergelson J, Manter DK, Vivanco JM (2008) Root exudates regulate soil fungal community composition and diversity. Appl Environ Microbiol 74:738-744.

Budiharjo A, Chowdhury SP, Dietel K, Beator B, Dolgova O, Fan B, Bleiss W, Ziegler J, Schmid M, Hartmann A, Borriss R (2014) Transposon mutagenesis of the plant-associated Bacillus amyloliquefaciens ssp plantarum FZB42 revealed that the $n f r A$ and RBAM17410 genes are involved in plant-microbe-interactions. PLoS One 9:e98267.

Chan WY, Dietel K, Lapa SV, Avdeeva LV, Borriss R, Reva ON (2013) Draft genome sequence of Bacillus atrophaeus UCMB-5137, a plant growth-promoting rhizobacterium. Genome Announc 1:e00233-13.

Chen XH, Koumoutsi A, Scholz R, Eisenreich A, Schneider K, Heinemeyer I, Morgenstern B, Voss B, Hess WR, Reva O, Junge H, Voigt B, Jungblut PR, Vater J, Süssmuth R, Liesegang H, Strittmatter A, Gottschalk G, Borriss R (2007) Comparative analysis of the complete genome sequence of the plant growth-promoting bacterium Bacillus amyloliquefaciens FZB42. Nat Biotechnol 25:1007-1014.

Dennis PG, Miller AJ, Hirsch PR (2010) Are root exudates more important than other sources of rhizodeposits in structuring rhizosphere bacterial communities? FEMS Microbiol Ecol 72:313-327.

Eraso JM, Markillie LM, Mitchell HD, Taylor RC, Orr G, Margolin W (2014) The highly conserved MraZ protein is a transcriptional regulator in Escherichia coli. J Bacteriol 196:2053-2066.

Eymann C, Homuth G, Scharf C, Hecker M (2002) Bacillus subtilis functional genomics: global characterization of the stringent response by proteome and transcriptome analysis. J Bacteriol 184:2500-2520.

Fan B, Chen XH, Budiharjo A, Bleiss W, Vater J, Borriss R (2011) Efficient colonization of plant roots by the plant growth promoting bacterium Bacillus amyloliquefaciens FZB42, engineered to express green fluorescent protein. J Biotechnol 151:303-311.

Fan B, Carvalhais LC, Becker A, Fedoseyenko D, von Wirén N, Borriss R (2012) Transcriptomic profiling of Bacillus amyloliquefaciens FZB42 in response to maize root exudates. BMC Microbiol 12:116.

Fan B, Boriss R, Bleiss W, Wu X (2013) Gram positive rhizobacterium Bacillus amyloliquefaciens FZB42 colonizes three types of plants in different patterns. J Microbiol 51:544.

Fan B, Li L, Chao Y, Förstner K, Vogel J, Borriss R, Wu XQ (2015) dRNA-Seq reveals genomewide TSSs and noncoding RNAs of plant beneficial rhizobacterium Bacillus amyloliquefaciens FZB42. PLoS One 10:e0142002.

Farag MA, Zhang H, Ryu CM (2013) Dynamic chemical communication between plants and bacteria through airborne signals: induced resistance by bacterial volatiles. J Chem Ecol 39:1007-1018. 
Feehily C, Karatzas KA (2013) Role of glutamate metabolism in bacterial responses towards acid and other stresses. J Appl Microbiol 114:11-24.

Fleiss JL, Levin B, Paik MC (2013) Statistical methods for rates and proportions. Third edition. John Wiley \& Sons.

Geiger T, Wolz C (2014) Intersection of the stringent response and the CodY regulon in low GC Gram-positive bacteria. Int J Med Microbiol 304:150-155.

Glick RB (1995) The enhancement of plant growth promotion by free living bacterial. Can J Microbiol 41:109-117.

Görke B, Stülke J (2008) Carbon catabolite repression in bacteria: many ways to make the most out of nutrients. Nat Rev Microbiol 6:613-624.

Gupta M, Rao KK (2014) Phosphorylation of DegU is essential for activation of amyE expression in Bacillus subtilis. J Biosci 39:747-752.

Hecker M, Pané-Farré J, Völker U (2007) SigB-dependent general stress response in Bacillus subtilis and related gram-positive bacteria. Annu Rev Microbiol 61:215-236.

Houry A, Briande R, Aymerich S, Gohar M (2010) Involvement of motility and flagella in Bacillus cereus biofilm formation. Microbiol 156:1009-1018.

Karp PD, Paley SM, Krummenacker M, Latendresse M, Dale JM, Lee TJ, Kaipa P, Gilham F, Spaulding A, Popescu L, Altman T, Paulsen I, Keseler IM, Caspi R (2010) Pathway Tools version 13.0: integrated software for pathway/genome informatics and systems biology. Brief Bioinform 11:40-79.

Kearns DB, Chu F, Branda SS, Kolter R, Losick R (2005) A master regulator for biofilm formation by Bacillus subtilis. Mol Microbiol 55:739-749.

Kierul K, Voigt B, Albrecht D, Chen XH, Carvalhais LC, Borriss R (2015) Influence of root exudates on the extracellular proteome of the plant growth-promoting bacterium Bacillus amyloliquefaciens FZB42. Microbiol 161:131-147.

Kohlstedt M, Sappa PK, Meyer H, Maaß S, Zaprasis A, Hoffmann T, Becker J, Steil L, Hecker M, van Dijl JM, Lalk M, Mäder U, Stülke J, Bremer E, Völker U, Wittmann C (2014) Adaptation of Bacillus subtilis carbon core metabolism to simultaneous nutrient limitation and osmotic challenge: a multi-omics perspective. Environ Microbiol 16:1898-1917.

Lamb C, Dixon RA (1997) The oxidative burst in plant disease resistance. Annu Rev Plant Physiol Plant Mol Biol 48:251-275.

Lapa SV, Reva OM (2005) Some properties of Bacillus subtilis strains active against rotting agents on strawberries and fruit. Mikrobiol Z 67:22-31.

Lengeler JW, Postma PW (1999) Global regulatory networks and signal transduction pathways. In: Lengeler JW, Drews G, and Schlegel HG (eds) Biology of the prokaryotes, Blackwell Science, New York, USA, pp 491523.

Lugtenberg BJJ, Kamilova F (2009) Plant-growth-promoting rhizobacteria. Annu Rev Microbiol 63:541-556.

Magoc T, Wood D, Salzberg SL (2013) EDGE-pro: estimated degree of gene expression in prokaryotic genomes. Evol Bioinform Online 9:127-136. 
Mark GL, Dow JM, Kiely PD, Higgins H, Haynes J, Baysse C, Abbas A, Foley T, Franks A, Morrissey J, O'Gara F (2005) Transcriptome profiling of bacterial responses to root exudates identifies genes involved in microbeplant interactions. PNAS 102:17454-17459.

Matilla M, Espinosa-Urgel M, Rodriguez-Herva J, Ramos J, Ramos-Gonzalez M (2007) Genomic analysis reveals the major driving forces of bacterial life in the rhizosphere. Genome Biol 8:R179.

Michna RH, Zhu B, Mäder U, Stülke J (2015) SubtiWiki 2.0-an integrated database for the model organism Bacillus subtilis. Nucleic Acids Res 2015 (Epub ahead of print).

Meile JC, Wu LJ, Ehrlich SD, Errington J, Noirot P (2006) Systematic localisation of proteins fused to the green fluorescent protein in Bacillus subtilis: identification of new proteins at the DNA replication factory. Proteomics 6:2135-2146.

Msadek T, Kunst F, Klier A, Rapoport G (1991) DegS-DegU and ComP-ComA modulator-effector pairs control expression of the Bacillus subtilis pleiotropic regulatory gene degQ. J Bacteriol 173:2366-2377.

Murray EJ, Kiley TB, Stanley-Wall NR (2009) A pivotal role for the response regulator DegU in controlling multicellular behavior. Microbiol 155:1-8.

Nicolas P, Mäder U, Dervyn E, Rochat T, Leduc A, Pigeonneau N, Bidnenko E, Marchadier E, Hoebeke M, Aymerich S, Becher D, Bisicchia P, Botella E, Delumeau O, Doherty G, Denham EL, Fogg MJ, Fromion V, Goelzer A, Hansen A, Härtig E, Harwood CR, Homuth G, Jarmer H, Jules M, Klipp E, Le Chat L, Lecointe F, Lewis P, Liebermeister W, March A, Mars RA, Nannapaneni P, Noone D, Pohl S, Rinn B, Rügheimer F, Sappa PK, Samson F, Schaffer M, Schwikowski B, Steil L, Stülke J, Wiegert T, Devine KM, Wilkinson AJ, van Dijl JM, Hecker M, Völker U, Bessières P, Noirot P (2012) Condition-dependent transcriptome reveals high-level regulatory architecture in Bacillus subtilis. Science 335:1103-1106.

Omer BS, Pollak S, Hizi D, Eldar A (2015) The RapP-PhrP quorum-sensing system of Bacillus subtilis strain NCIB3610 affects biofilm formation through multiple targets, due to an atypical signal-insensitive allele of RapP. J Bacteriol 197:592-602.

Pinzón-Arango PA, Scholl G, Nagarajan R, Mello CM, Camesano TA (2009) Atomic force microscopy study of germination and killing of Bacillus atrophaeus spores. J Mol Recognit 22:373-379.

Podile AR, Kishore K (2007) Plant growth-promoting rhizobacteria. In: Gnanamanickam SS (ed) Plant Associated Bacteria, Springer, the Netherlands, pp 195-230.

Ratnayake-Lecamwasam M, Serror P, Wong KW, Sonenshein AL (2001) Bacillus subtilis CodY represses earlystationary-phase genes by sensing GTP levels. Genes Dev 15:1093-1103.

Reva ON, Dixelius C, Meijer J, Priest FG (2004) Taxonomic characterization and plant colonizing abilities of some bacteria related to Bacillus amyloliquefaciens and Bacillus subtilis. FEMS Microbiol Ecol 48:249-259.

Ruzheinikov SN, Das SK, Sedelnikova SE, Hartley A, Foster SJ, Horsburgh MJ, Cox AG, McCleod CW, Mekhalfia A, Blackburn GM, Rice DW, Baker PJ (2001) The 12 A structure of a novel quorum-sensing protein, Bacillus subtilis LuxS. J Mol Biol 313:111-122.

Safronova LA, Zelena LB, Klochko VV, Reva ON (2012) Does the applicability of Bacillus strains in probiotics rely upon their taxonomy? Can J Microbiol 58:212-219. 
Sappa PK (2013) Multi-omics based characterization of various stress responses in Bacillus subtilis. Naturwissenschaftlichen Fakultät der Ernst-Moritz-Arndt-Universität Greifswald, PhD thesis.

Serror P, Sonenshein AL (1996) CodY is required for nutritional repression of Bacillus subtilis genetic competence. J Bacteriol 178:5910-5915.

Sierro N, Makita Y, de Hoon MJL, Nakai K (2008) DBTBS: a database of transcriptional regulation in Bacillus subtilis containing upstream intergenic conservation information. Nucleic Acids Res 36:D93-D96.

Sivasakthi S, Usharani G, Saranraj P (2014) Biocontrol potentiality of plant growth promoting rhizobacteria (PGPR) - Pseudomonas fluorescens and Bacillus subtilis: a review. Afr J Agric Res 9:1265-1277.

Tamura K, Stecher G, Peterson D, Filipski A, Kumar S (2013) MEGA6: molecular evolutionary genetics analysis version 60. Mol Biol Evol 30:2725-2729.

Vessey JK (2003) Plant growth promoting rhizobacteria as biofertilizers. Plant and Soil 255:571-586.

Völker U, Engelmann S, Maul B, Riethdorf S, Völker A, Schmid R, Mach H, Hecker M (1994) Analysis of the induction of general stress proteins of Bacillus subtilis. Microbiology 140:741-752.

Wacker I, Ludwig H, Reif I, Blencke HM, Detsch C, Stülke J (2003) The regulatory link between carbon and nitrogen metabolism in Bacillus subtilis: regulation of the gltAB operon by the catabolite control protein CcpA. Microbiol 149:3001-3009.

Wagner EG, Romby P (2015) Small RNAs in bacteria and archaea: who they are, what they do, and how they do it. Adv Genet 90:133-208.

Wattam AR, D Abraham, O Dalay, TL Disz, T, Driscoll, JL, Gabbard, JJ, Gillespie JJ, Gough R, Hix D, Kenyon R, Machi D, Mao C, Nordberg EK, Olson R, Overbeek R, Pusch GD, Shukla M, Schulman J, Stevens RL, Sullivan DE, Vonstein V, Warren A, Will R, Wilson MJ, Yoo HS, Zhang C, Zhang Y, Sobral BW (2014) PATRIC, the bacterial bioinformatics database and analysis resource. Nucleic Acids Res 42:D581-D591.

Wright PR, Georg J, Mann M, Sorescu DA, Richter AS, Lott S, Kleinkauf R, Hess WR, Backofen R (2014) CopraRNA and IntaRNA: predicting small RNA targets, networks and interaction domains. Nucleic Acids Res 42:W119-W123.

Wünsche A, Hammer E, Bartholomae M, Völker U, Burkovski A, Seidel G, Hillen W (2012) CcpA forms complexes with CodY and RpoA in Bacillus subtilis. FEBS 279:2201-2214.

Yssel A, Reva O, Tastan Bishop O (2011) Comparative structural bioinformatics analysis of Bacillus amyloliquefaciens chemotaxis proteins within Bacillus subtilis group. Appl Microbiol Biotechnol 92:9971008. 
Table S1. Functional grouping of genes of Bacillus atrophaeus UCMB-5137 regulated by maize root exudate (fold change $\geq 3 ; \mathrm{p} \leq 0.05$ ).

\begin{tabular}{|c|c|c|c|c|c|}
\hline \multicolumn{2}{|c|}{ Functional groups and reactions } & $\begin{array}{l}\text { Up- } \\
\text { regulated }\end{array}$ & $\begin{array}{l}\text { Down- } \\
\text { regulated }\end{array}$ & Activator* & Repressor* \\
\hline \multicolumn{6}{|c|}{ Aerobic respiration } \\
\hline $\operatorname{cta} A$ & \begin{tabular}{|l} 
cytochrome oxidase \\
biogenesis, heme A synthase
\end{tabular} & D068_15390 & & ResD,SigE & \\
\hline$y k u U$ & $\begin{array}{l}\text { alkyl hydroperoxide } \\
\text { reductase }\end{array}$ & D068_14700 & & & AbrB \\
\hline$q c r B$ & $\begin{array}{l}\text { menaquinol-cytochrome c } \\
\text { reductase cytochrome b }\end{array}$ & & D068_22850 & ResD & AbrB \\
\hline \multicolumn{6}{|c|}{ Anaerobic respiration } \\
\hline$n f r A$ & nitrate respiration & D068_40270 & & SigD, Spx & Spo0A \\
\hline narG & $\begin{array}{l}\text { respiratory nitrate reductase } \\
\text { alpha chain }\end{array}$ & & D068_39480 & Fnr & \\
\hline yyaE & $\begin{array}{l}\text { selenocysteine-containing } \\
\text { anaerobic dehydrogenases }\end{array}$ & & D068_43360 & & \\
\hline \multicolumn{6}{|c|}{ Amine and polyamine metabolism } \\
\hline speD & spermidine biosynthesis I & D068_28960 & & & CcpN \\
\hline$g u b D$ & $\begin{array}{l}\text { 4-aminobutyrate } \\
\text { degradation II and III; GABA } \\
\text { shunt }\end{array}$ & D068_32090 & & GabR, SigB & \\
\hline \multicolumn{6}{|c|}{ Amino acid biosynthesis, degradation and transportation } \\
\hline cysE & cystein biosynthesis I & & D068_00800 & & \\
\hline hisA & \multirow{4}{*}{$\begin{array}{l}\text { histidine/imidazole } \\
\text { biosynthesis }\end{array}$} & & D068_36810 & & \\
\hline hisD & & & D068_36840 & & \\
\hline hisF & & & D068_36800 & & \\
\hline \multirow[t]{2}{*}{ hisH } & & & D068_36820 & & \\
\hline & homocystein biosynthesis & & D068_36350 & & \\
\hline proB & proline biosynthesis I & & D068_13560 & & \\
\hline$y c g M$ & \begin{tabular}{|l|} 
proline \\
dehydrogenase/oxidase
\end{tabular} & & D068_03140 & PutR, Spo0A & CodY \\
\hline$y c g N$ & $\begin{array}{l}\text { delta-1-pyrroline-5- } \\
\text { carboxylate dehydrogenase }\end{array}$ & & D068_03150 & PutR, Spo0A & CodY \\
\hline cysC & $\begin{array}{l}\text { sulfate activation for } \\
\text { sulfonation }\end{array}$ & & D068_16200 & & CymR \\
\hline hutU & histidine degradation I & & D068_41790 & & CcpA, CodY \\
\hline hutM & $\begin{array}{l}\text { histidine transport } \\
\text { permease }\end{array}$ & & D068_41820 & & CcpA, CodY \\
\hline yckJ & $\begin{array}{l}\text { TcyB L-cystine } \mathrm{ABC} \\
\text { transporter }\end{array}$ & & D068_32510 & & \\
\hline$y d g F$ & $\begin{array}{l}\text { D-serine/D-alanine/glycine } \\
\text { transporter }\end{array}$ & & D068_42470 & & \\
\hline yxeN & amino acid $A B C$ transporter & & D068_32320 & & CymR \\
\hline ycs $G$ & $\begin{array}{l}\text { branched chain amino acids } \\
\text { transporter }\end{array}$ & & D068_31920 & TnrA & KipR \\
\hline$y c g O$ & $\begin{array}{l}\text { PutP proline/sodium } \\
\text { symporter }\end{array}$ & & D068_03160 & PutR & \\
\hline \multicolumn{4}{|c|}{ Antibiotic and bacteriocin biosynthesis } & & \\
\hline
\end{tabular}




\begin{tabular}{|c|c|c|c|c|c|}
\hline$y \operatorname{sh} B$ & colicin $\mathrm{V}$ biosynthesis & D068_28480 & & & \\
\hline pksE-R & $\begin{array}{l}\text { bacillaene biosynthesis } \\
\text { operon }\end{array}$ & & $\begin{array}{l}\text { D068_17790 } \\
-17890\end{array}$ & & \\
\hline$y c b N$ & \multirow[t]{2}{*}{ bacitracin transporters } & & D068_02530 & & \\
\hline$y c b 0$ & & & D068_02540 & & \\
\hline plpC & $\begin{array}{l}\text { plipastatin/fengycin } \\
\text { synthetase }\end{array}$ & & D068_20095 & & \\
\hline srfAA & \multirow[t]{2}{*}{ surfactin synthetase } & & D068_03520 & \multirow[t]{2}{*}{ ComA, PerR } & \multirow{2}{*}{$\begin{array}{l}\text { Abh, CodY, } \\
\text { Spx }\end{array}$} \\
\hline srfAB & & & D068_03530 & & \\
\hline yuil & $\begin{array}{l}\text { trilactone hydrolase, } \\
\text { bacillibactin siderophore } \\
\text { biosynthesis }\end{array}$ & & D068_33600 & & AbrB, Fur \\
\hline$y b d B$ & SkfF cannibalism toxin & & D068_01840 & PhoP, Spo0A & AbrB \\
\hline \multicolumn{6}{|c|}{ Aromatic compound biosynthesis and degradation } \\
\hline yitw & $\begin{array}{l}\text { aromatic ring hydroxylating } \\
\text { enzyme }\end{array}$ & D068_11280 & & & \\
\hline \multicolumn{6}{|c|}{ Biofilm formation and regulation } \\
\hline luxS & $\begin{array}{l}\text { S-adenosyl-L-methionine } \\
\text { cycle I; autoinducer Al-2 } \\
\text { biosynthesis }\end{array}$ & D068_30750 & & & \\
\hline$y m c A$ & biofilm formation regulation & D068_17660 & & & \\
\hline yugO & putative $\mathrm{K}+$ channel protein & & D068_32890 & & \\
\hline$y w q E$ & protein dephosphorylation & & D068_38300 & & AbrB \\
\hline \multicolumn{6}{|c|}{ Carbohydrate biosynthesis and degradation } \\
\hline sacA & $\begin{array}{l}\text { sucrose degradation III } \\
\text { (sucrose invertase) }\end{array}$ & & D068_40170 & & CсpA \\
\hline yfnG & $\begin{array}{l}\text { galactose degradation I } \\
\text { (Leloir pathway); galactose } \\
\text { degradation III; UDP-D- } \\
\text { galactose biosynthesis }\end{array}$ & & D068_07090 & SigK & \\
\hline$y c b C$ & \multirow{2}{*}{$\begin{array}{l}\text { D-glucarate/D-galactarate } \\
\text { degradation II }\end{array}$} & & D068_02410 & & YcbG \\
\hline$y c b D$ & & & D068_02420 & & YcbG \\
\hline pelB & $\begin{array}{l}\text { pectin } \\
\text { synthesis/degradation }\end{array}$ & & D068_41580 & & \\
\hline $\mathrm{licH}$ & $\begin{array}{l}\text { arbutin/salicin-6-phosphate } \\
\text { hydrolysation }\end{array}$ & & D068_27630 & LicR & CсpA \\
\hline$g \operatorname{lgC}$ & $\begin{array}{l}\text { glycogen biosynthesis I } \\
\text { (from ADP-D-glucose) }\end{array}$ & & D068_31080 & SigE & \\
\hline$x y n D$ & $\begin{array}{l}\text { cellulose and hemicellulose } \\
\text { degradation (cellulolosome) }\end{array}$ & & D068_19950 & & AbrB \\
\hline yve $B$ & levanase & & D068_36400 & DegU & \\
\hline \multirow[t]{2}{*}{ RhiN } & $\begin{array}{l}\text { rhamnogalacturonides } \\
\text { degradation protein }\end{array}$ & & D068_06760 & & \\
\hline & chitin binding protein & & D068_21820 & & \\
\hline yyaE & $\begin{array}{l}\text { RpiR sialic acid utilization } \\
\text { regulator }\end{array}$ & & D068_01620 & & \\
\hline yiss & $\begin{array}{l}\text { myo-inositol degradation II, } \\
\text { myo-, chiro- and scillo- } \\
\text { inositol degradation }\end{array}$ & & D068_04260 & & \\
\hline
\end{tabular}




\begin{tabular}{|c|c|c|c|c|c|}
\hline IolF & myo-inositol transporter & & D068_42110 & & CcpA, IolR \\
\hline ioll & inosose isomerase & & D068_42080 & & CcpA, IolR \\
\hline rbsk & $\begin{array}{l}\text { alpha-D-ribofuranose } \\
\text { phosphorilation to D-ribose } \\
\text { 5-phosphate }\end{array}$ & & D068_37920 & AbrB & CсpA \\
\hline$a \operatorname{coB}$ & transketolase & & D068_07970 & AcoR, SigL & CcpA \\
\hline yufO & \multirow{2}{*}{$\begin{array}{l}\text { unspecified monosaccharide } \\
A B C \text { transporters }\end{array}$} & & D068_33130 & & CodY \\
\hline yufP & & & D068_33140 & & CodY \\
\hline \multicolumn{6}{|c|}{ Carbon metabolism and glycolysis } \\
\hline$y w k A$ & \multirow[b]{2}{*}{$\begin{array}{l}\text { gluconeogenesis I; glycolysis } \\
\text { III; heterolactic } \\
\text { fermentation; sucrose } \\
\text { biosynthesis I, glycerol } \\
\text { degradation to butanol }\end{array}$} & D068_39220 & & MalR & \\
\hline gapA & & D068_35950 & & & CggR \\
\hline yqiK & $\begin{array}{l}\text { glycerophosphoryl diester, } \\
\text { phosphodiesterase }\end{array}$ & D068_24670 & & & \\
\hline$g / p D$ & $\begin{array}{l}\text { aerobic glycerol-3- } \\
\text { phosphate dehydrogenase }\end{array}$ & D068_09280 & & AbrB & CcpA \\
\hline$p d h A$ & $\begin{array}{l}\text { pyruvate dehydrogenase E1 } \\
\text { component alpha subunit }\end{array}$ & & D068_15080 & & $\begin{array}{l}\text { ppGpp, } \\
\text { YwaC }\end{array}$ \\
\hline pyrC & dihydroorotase & & D068_16080 & PyrR & ppGpp \\
\hline iols & $\begin{array}{l}\text { oxidoreductase, aldo/keto } \\
\text { reductase }\end{array}$ & & D068_06830 & & IOIR \\
\hline \multicolumn{6}{|c|}{ Cell division } \\
\hline $\operatorname{divIVA}$ & $\begin{array}{l}\text { cell division initiation } \\
\text { protein }\end{array}$ & D068_16000 & & & Spo0A \\
\hline yyaA & $\begin{array}{l}\text { ParB chromosome } \\
\text { partitioning protein }\end{array}$ & D068_43440 & & ComK & \\
\hline ftsW & cell division protein & D068_40290 & & SigM & \\
\hline gpsB & cell division protein & D068_22460 & & & \\
\hline \multicolumn{6}{|c|}{ Cell wall biosynthesis and membrane proteins } \\
\hline yocA & $\begin{array}{l}\text { antigen A homolog; putative } \\
\text { transposon-related lytic } \\
\text { enzyme }\end{array}$ & D068_20960 & & & \\
\hline $\operatorname{tag} D$ & teichoic acid biosynthesis & D068_37680 & & WalR & PhoP \\
\hline $\operatorname{tag} O$ & $\begin{array}{l}\text { peptidoglycan biosynthesis I } \\
\text { and } V \text { (beta-lactam } \\
\text { resistance) }\end{array}$ & D068_37460 & & & \\
\hline $\sec G$ & $\begin{array}{l}\text { preprotein translocase } \\
\text { subunit }\end{array}$ & D068_35560 & & & \\
\hline yocH & cell wall binding protein & D068_21050 & & Spo0A, WalR & AbrB \\
\hline yfmQ & $\begin{array}{l}\text { holin associated protein, } \\
\text { membrane protein }\end{array}$ & D068_23710 & & & \\
\hline yneJ & \multirow{4}{*}{$\begin{array}{l}\text { integral inner membrane } \\
\text { proteins }\end{array}$} & D068_19650 & & & \\
\hline yozB & & D068_20970 & & & \\
\hline yqjG & & D068_24390 & & MifM & \\
\hline yuid & & D068_33670 & & & \\
\hline gtaB & $\begin{array}{l}\text { sucrose degradation II, UDP- } \\
\text { glucose biosynthesis }\end{array}$ & D068_37620 & & SigB & \\
\hline tuaA & undecaprenyl-phosphate & & D068_37540 & PhoP & \\
\hline
\end{tabular}




\begin{tabular}{|c|c|c|c|c|c|}
\hline & $\begin{array}{l}\text { galactosephosphotransferas } \\
\text { e }\end{array}$ & & & & \\
\hline yubE & $\begin{array}{l}\mathrm{N} \text {-acetylmuramoyl-L-alanine } \\
\text { amidase (cell wall } \\
\text { degradation/ turnover) }\end{array}$ & & D068_05240 & & \\
\hline \multirow[t]{3}{*}{$y k f C$} & $\begin{array}{l}\text { cell wall endopeptidase } \\
\text { NLP/P60 }\end{array}$ & & D068_13420 & & CodY \\
\hline & \multirow{2}{*}{$\begin{array}{l}\text { LysM domain containing } \\
\text { peptidoglycan-binding } \\
\text { protein (horizontally } \\
\text { acquired) }\end{array}$} & & D068_05530 & & \\
\hline & & & D068_05540 & & \\
\hline \multicolumn{6}{|c|}{ Chemotaxis and motility } \\
\hline flaA & FlaA flagellin protein & D068_37280 & & SigD & $\begin{array}{l}\text { CodY, CsrA, } \\
\text { ScoC }\end{array}$ \\
\hline$f \mid b D$ & \multirow[t]{4}{*}{ flagellin proteins } & & D068_16900 & & \\
\hline$f l h B$ & & & D068_16990 & SigD & $\begin{array}{l}\text { CodY, } \\
\text { SpoOA }\end{array}$ \\
\hline fliY & & & D068_16930 & SigD & $\begin{array}{l}\text { CodY, } \\
\text { SpoOA }\end{array}$ \\
\hline flhA & & & D068_17000 & SigD & $\begin{array}{l}\text { CodY, } \\
\text { SpoOA }\end{array}$ \\
\hline$t / p A$ & $\begin{array}{l}\text { methyl-accepting } \\
\text { chemotaxis protein }\end{array}$ & & D068_32780 & SigD & AbrB \\
\hline \multicolumn{6}{|c|}{ Co-factor biosynthesis and utilization } \\
\hline ppnK & NAD kinase & D068_29420 & & & \\
\hline$y w f l$ & HemQ hemoprotein & D068_39940 & & & \\
\hline atpl & ATP synthase protein 12 & D068_39040 & & & $\begin{array}{l}\text { ppGpp, } \\
\text { YwaC }\end{array}$ \\
\hline moaC & $\begin{array}{l}\text { molybdenium cofactor } \\
\text { biosynthesis }\end{array}$ & D068_04680 & & & \\
\hline ribT & $\begin{array}{l}\text { vitamin B synthesis, } \\
\text { acetyltransferase }\end{array}$ & D068_23580 & & & \\
\hline yqeY & GatB transamidase & D068_25960 & & & \\
\hline ytaP & \multirow{4}{*}{$\begin{array}{l}\text { biotin biosynthesis; fatty } \\
\text { acid biosynthesis }\end{array}$} & & D068_30330 & & \\
\hline bioD & & & D068_30270 & & BirA \\
\hline bioB & & & D068_30260 & & BirA \\
\hline yqjQ & & & D068_03660 & & \\
\hline tenl & \multirow{3}{*}{$\begin{array}{l}\text { thiamin biosynthesis and } \\
\text { salvage }\end{array}$} & & D068_11830 & & \\
\hline thic & & & D068_08720 & & \\
\hline thiF & & & D068_42760 & & \\
\hline yaaD & \multirow{2}{*}{$\begin{array}{l}\text { PdxST pyridoxine } \\
\text { biosynthesis glutamine } \\
\text { amidotransferases }\end{array}$} & & D068_18930 & & SpoOA \\
\hline yaaE & & & D068_18940 & & SpoOA \\
\hline \multicolumn{6}{|c|}{ Fatty acid biosynthesis } \\
\hline$g / p Q$ & $\begin{array}{l}\text { glycerophosphoryl diester, } \\
\text { phosphodiesterase }\end{array}$ & & D068_02080 & PhoP & CcpA \\
\hline$p c r B$ & $\begin{array}{l}\text { S-3-O-geranylgeranylglyceryl } \\
\text { phosphate synthase }\end{array}$ & & D068_06290 & & \\
\hline$y x a A$ & glycerate kinase & & D068_42360 & & AbrB \\
\hline
\end{tabular}




\begin{tabular}{|c|c|c|c|c|c|}
\hline yusk & $\begin{array}{l}\text { fatty acid beta-oxidation } \\
\text { pathway }\end{array}$ & & D068_34610 & SdpR & CcpA, FadR \\
\hline yqjQ & $\begin{array}{l}\text { short-chain } \\
\text { dehydrogenase/reductase }\end{array}$ & & D068_03670 & & \\
\hline pgsA & $\begin{array}{l}\text { CDP-diacylglycerol--glycerol- } \\
\text { 3-phosphate 3- } \\
\text { phosphatidyltransferase }\end{array}$ & & D068_17520 & & \\
\hline yqiD & $\begin{array}{l}\text { ThiJ/Pfpl family protein, } \\
\text { biosynthesis of lipids }\end{array}$ & & D068_36480 & & \\
\hline \multicolumn{6}{|c|}{ Iron metabolism } \\
\hline$y v r A$ & $\begin{array}{l}\text { adenosylcobalamin salvage } \\
\text { from cobinamide II, iron } \\
\text { metabolism }\end{array}$ & & D068_34950 & & \\
\hline$d h b C$ & \multirow{2}{*}{$\begin{array}{l}\text { 1,4-dihydroxyl-2-naphthoate } \\
\text { biosymthesis I; 2,3- } \\
\text { dihydrobenzoate } \\
\text { biosynthesis }\end{array}$} & & D068_33580 & & AbrB, Fur \\
\hline$d h b A$ & & & D068_33590 & & AbrB, Fur \\
\hline$d h b E$ & vibriobactin biosynthesis & & D068_33570 & & AbrB, Fur \\
\hline \multicolumn{6}{|c|}{ Nitrogen utilization } \\
\hline nasA & nitrate/nitrite transporter & & D068_03270 & TnrA & \\
\hline ureA & \multirow[t]{2}{*}{ urea degradation II } & & D068_38790 & $\begin{array}{l}\text { PucR, SigH, } \\
\text { TnrA }\end{array}$ & CodY, GInR \\
\hline ureB & & & D068_38780 & $\begin{array}{l}\text { PucR, SigH, } \\
\text { TnrA }\end{array}$ & CodY, GInR \\
\hline \multicolumn{6}{|c|}{ Nucleotide biosynthesis and degradation } \\
\hline guaC & $\begin{array}{l}\text { nucleotide } \\
\text { biosynthesis/acquisition }\end{array}$ & & D068_33750 & CodY & PurR \\
\hline purA & $\begin{array}{l}\text { adenosine ribonucleotides } \\
\text { de novo biosynthesis }\end{array}$ & & D068_42840 & & PurR \\
\hline purN & $\begin{array}{l}\text { 5-aminoimidazole } \\
\text { ribonucleotide biosynthesis; } \\
\text { tetrahydropholate salvage }\end{array}$ & & D068_06180 & & PurR \\
\hline \multirow[t]{2}{*}{ purs } & $\begin{array}{l}\text { 5-aminoimidazole } \\
\text { ribonucleotide biosynthesis }\end{array}$ & & D068_06130 & & PurR \\
\hline & $\begin{array}{l}\text { pyrimidine } \\
\text { deoxyribonucleotides } \\
\text { biosynthesis }\end{array}$ & & D068_04970 & & \\
\hline \multirow[t]{3}{*}{ pyrB } & $\begin{array}{l}\text { UMP biosynthesis; pyruvate } \\
\text { decarboxylation to acetyl } \\
\text { CoA }\end{array}$ & & D068_16070 & PyrR & \\
\hline & $\begin{array}{l}\text { adenine/guanine } \\
\text { phosphoribosyltransferases }\end{array}$ & & D068_02880 & & \\
\hline & ATP/GTP-binding protein & & D068_02890 & & \\
\hline \multicolumn{6}{|c|}{ Protein translation, maturation, activation and utilization } \\
\hline yfhP & $\begin{array}{l}\text { cysteinyl-tRNA synthetase } \\
\text { related protein }\end{array}$ & D068_08500 & & & \\
\hline ppiB & protein folding acceleration & D068_23750 & & & \\
\hline prfA & $\begin{array}{l}\text { peptide chain release factor } \\
2\end{array}$ & D068_37200 & & & \\
\hline
\end{tabular}




\begin{tabular}{|c|c|c|c|c|c|}
\hline$y f \mid G$ & $\begin{array}{l}\mathrm{N} \text {-terminal amino acid } \\
\text { release }\end{array}$ & D068_07470 & & & \\
\hline $\operatorname{sip} T$ & \multirow{2}{*}{$\begin{array}{l}\text { leader sequence cleavage, } \\
\text { signal peptidase }\end{array}$} & D068_14890 & & DegU & \\
\hline $\operatorname{sips}$ & & D068_23650 & & & \\
\hline ykuE & \multirow[t]{4}{*}{ protein kinases } & D068_14540 & & & \\
\hline$y j b H$ & & D068_11720 & & & \\
\hline$y r z F$ & & D068_27510 & & & \\
\hline prkC & & & D068_16370 & & \\
\hline \multicolumn{6}{|c|}{ Ribosomal proteins } \\
\hline$r b f A$ & ribosome-binding factor $\mathrm{A}$ & D068_17260 & & & $\begin{array}{l}\text { ppGpp, } \\
\text { YwaC }\end{array}$ \\
\hline$r p s B$ & SSU ribosomal protein S2p & D068_17100 & & & $\begin{array}{l}\text { ppGpp, } \\
\text { YwaC }\end{array}$ \\
\hline rpsL & SSU ribosomal protein S9p & D068_01340 & & & $\begin{array}{l}\text { ppGpp, } \\
\text { YwaC }\end{array}$ \\
\hline rpsT & SSU ribosomal protein S20p & D068_26110 & & & \\
\hline rpsU & SSU ribosomal protein S21p & D068_25970 & & & \\
\hline$r p / T$ & LSU ribosomal protein L20p & D068_28780 & & & $\begin{array}{l}\text { ppGpp, } \\
\text { YwaC }\end{array}$ \\
\hline ytiA & LSU ribosomal protein L31p & D068_30790 & & SigB & Zur \\
\hline rpmF & LSU ribosomal protein L32p & D068_15640 & & & $\begin{array}{l}\text { ppGpp, } \\
\text { YwaC }\end{array}$ \\
\hline$y / b N$ & $\begin{array}{l}\text { ribosomal protein clustered } \\
\text { with L32p }\end{array}$ & D068_15630 & & & $\begin{array}{l}\text { ppGpp, } \\
\text { YwaC }\end{array}$ \\
\hline$y v y D$ & $\begin{array}{l}\text { ribosomal subunit interface } \\
\text { protein }\end{array}$ & D068_37220 & & SigB, SigH & \\
\hline$r p / B$ & LSU ribosomal protein L2p & & D068_01060 & & $\begin{array}{l}\text { ppGpp, } \\
\text { YwaC }\end{array}$ \\
\hline$r p / P$ & LSU ribosomal protein L16p & & D068_01080 & & $\begin{array}{l}\text { ppGpp, } \\
\text { YwaC }\end{array}$ \\
\hline $\operatorname{rim} M$ & 16S rRNA processing protein & & D068_16620 & & \\
\hline$y b x B$ & $\begin{array}{l}\text { ribosomal RNA small subunit } \\
\text { methyltransferas }\end{array}$ & & D068_00930 & & $\begin{array}{l}\text { ppGpp, } \\
\text { YwaC }\end{array}$ \\
\hline \multicolumn{6}{|c|}{ Replication, repair, recombination } \\
\hline$d n a N$ & \multirow{2}{*}{$\begin{array}{l}\text { DNA polymerase III beta } \\
\text { subunits }\end{array}$} & D068_00020 & & & Spo0A \\
\hline $\operatorname{din} G$ & & D068_26790 & & & \\
\hline \multicolumn{6}{|c|}{ Resistance to antibiotics and toxins } \\
\hline$y v a E$ & $\begin{array}{l}\text { ethidium bromide-methyl } \\
\text { viologen resistance protein } \\
\text { EmrE }\end{array}$ & & D068_04110 & & \\
\hline$p b p E$ & beta-lactamase & & D068_05680 & SigW & \\
\hline $\operatorname{Imr} B$ & $\begin{array}{l}\text { drug resistance transporter } \\
\text { EmrB/QacA }\end{array}$ & & D068_02650 & & LmrA \\
\hline yoaV & $\begin{array}{l}\text { drug/metabolite transporter } \\
\text { DMT }\end{array}$ & & D068_41730 & & \\
\hline \multicolumn{6}{|c|}{ Sporulation } \\
\hline yraG & spore coat protein $\mathrm{F}$ & D068_08690 & & SigG & \\
\hline sspJ & spore protein & D068_35180 & & SigG & \\
\hline yndM & sporulation protein & D068_19520 & & & \\
\hline yqfU & sporulation protein & D068_25650 & & SigG & \\
\hline
\end{tabular}




\begin{tabular}{|c|c|c|c|c|c|}
\hline yraF & sporulation protein & & D068_01970 & & \\
\hline yis $Y$ & $\begin{array}{l}\text { chlorination of organic } \\
\text { molecules }\end{array}$ & & D068_29590 & SigG & \\
\hline spsG & $\begin{array}{l}\mathrm{CMP}-\mathrm{N} \text {-acetylneuraminate } \\
\text { biosynthesis II, spore coat } \\
\text { protein }\end{array}$ & & D068_38680 & SigK & \\
\hline spsC & $\begin{array}{l}\text { PgIE 4-keto-6-deoxy-N- } \\
\text { Acetyl-D-hexosaminyl-Lipid } \\
\text { carrier aminotransferase }\end{array}$ & & D068_35870 & SigK & \\
\hline ytcA & $\begin{array}{l}\text { UDP-alpha-D-glucoronate } \\
\text { biosynthesis from UDP- } \\
\text { glucose }\end{array}$ & & D068_35880 & & \\
\hline $\cot \mathrm{C}$ & spore coat protein & & D068_06660 & SigE, SpollID & \\
\hline yesJ & $\begin{array}{l}\text { GNAT family } \\
\text { acetyltransferase }\end{array}$ & & D068_06670 & SigE, SpollID & \\
\hline ypjB & $\begin{array}{l}\text { spore formation membrane } \\
\text { associated protein }\end{array}$ & & D068_22820 & SigE & \\
\hline gerKA & spore germination protein & & D068_37880 & SigG & SpoVT \\
\hline$y b b E$ & $\begin{array}{l}\text { nylon-6 oligomer } \\
\text { degradation }\end{array}$ & & D068_01600 & & \\
\hline \multicolumn{6}{|c|}{ Stress response, detoxication, antibiotic resistance } \\
\hline$n f r A$ & $\begin{array}{l}\text { oxygen-insensitive NADPH } \\
\text { nitroreductase (oxidative } \\
\text { stress) }\end{array}$ & D068_40270 & & SigD, Spx & Spo0A \\
\hline$h x / B$ & $\begin{array}{l}\text { thiaminase II, resistance } \\
\text { against oxidative stress }\end{array}$ & D068_03470 & & HxIR & \\
\hline$y w b C$ & $\begin{array}{l}\text { lactoylglutathione lyase, } \\
\text { oxidative stress resistance }\end{array}$ & D068_40560 & & & \\
\hline ygaF & \multirow{2}{*}{$\begin{array}{l}\text { thiol peroxidase antioxidant } \\
\text { proteins, resistance against } \\
\text { oxidative stress }\end{array}$} & D068_08610 & & & \\
\hline$y j b c$ & & D068_11650 & & $\begin{array}{l}\text { SigB, SigM, } \\
\text { SigW, SigX }\end{array}$ & PerR \\
\hline$y j b L$ & $\begin{array}{l}\text { thiol management } \\
\text { oxidoreductase component }\end{array}$ & D068_11730 & & & \\
\hline$y k u V$ & thiol-disulfide isomerase & D068_14710 & & & AbrB \\
\hline $\operatorname{sod} A$ & $\begin{array}{l}\text { superoxide radicals } \\
\text { degradation }\end{array}$ & D068_25560 & & SigB & \\
\hline $\operatorname{trx} A$ & \multirow[t]{2}{*}{ thioredoxin pathway } & D068_28370 & & \multirow[t]{2}{*}{ SigB, Spx } & \multirow[t]{2}{*}{ CtsR } \\
\hline $\operatorname{trx} A$ & & D068_31340 & & & \\
\hline $\operatorname{trx} B$ & & D068_36650 & & Spx & \\
\hline yusE & & D068_34550 & & Spo0A & \\
\hline$m r g A$ & $\begin{array}{l}\text { metal ion oxidation for } \\
\text { incorporation into } \\
\text { corresponding proteins }\end{array}$ & D068_34740 & & & PerR \\
\hline yock & general stress protein & D068_21090 & & SigB & \\
\hline$y t x J$ & $\begin{array}{l}\text { NAD kinase, general stress } \\
\text { response }\end{array}$ & D068_29850 & & SigB, SigH & \\
\hline \multirow[t]{2}{*}{$\operatorname{csp} C$} & \multirow[t]{2}{*}{ cold-shock proteins } & D068_03770 & & & \\
\hline & & D068_23670 & & & \\
\hline$y k r L$ & HtpX heat shock protein & D068_13940 & & & Rok, YkrK \\
\hline yflT & heat stress induced protein & D068_07310 & & SigB & \\
\hline
\end{tabular}




\begin{tabular}{|c|c|c|c|c|c|}
\hline$y k z A$ & $\begin{array}{l}\text { OhrB organic hydroperoxide } \\
\text { resistance protein }\end{array}$ & D068_13600 & & SigB & \\
\hline$y / m G$ & $\begin{array}{l}\text { YggT integral membrane } \\
\text { protein involved in response } \\
\text { to extracytoplasmic stress } \\
\text { osmotic shock }\end{array}$ & D068_15980 & & & SpoOA \\
\hline nhaX & stress response protein & D068_09730 & & SigB & \\
\hline$y f k M$ & ThiJ/Pfpl family protein & D068_07580 & & SigB & Fur \\
\hline$y t x H$ & \multirow{2}{*}{$\begin{array}{l}\text { general stress response } \\
\text { proteins }\end{array}$} & D068_29860 & & SigB, SigH & \\
\hline$y t x G$ & & D068_29870 & & SigB, SigH & \\
\hline$y d a G$ & & D068_31760 & & SigB & \\
\hline$g s i B$ & & D068_31500 & & SigB, Sigl & \\
\hline$g s p A$ & & D068_40610 & & SigB & \\
\hline yugl & & D068_32960 & & & $\begin{array}{l}\text { ppGpp, } \\
\text { YwaC }\end{array}$ \\
\hline yxiE & & D068_41660 & & & CсрA \\
\hline$y f h L$ & SdpC immunity factor & D068_08450 & & SigB, SigW & \\
\hline$y w s B$ & & D068_37970 & & SigB & \\
\hline$c l p P$ & \multirow{3}{*}{$\begin{array}{l}\text { proteolysis and hydrolysis, } \\
\text { general stress response }\end{array}$} & D068_36470 & & SigB & CtsR \\
\hline yfhM & & D068_08460 & & SigB, SigW & \\
\hline $\operatorname{clpX}$ & & D068_28080 & & & CtsR \\
\hline ydil & $\begin{array}{l}\text { stress protection CAAX } \\
\text { amino terminal protease }\end{array}$ & D068_04730 & & & \\
\hline \multirow[t]{2}{*}{$y v g N$} & \multirow[t]{2}{*}{ stress response protein } & D068_01940 & & SigB & Sin $R$ \\
\hline & & D068_35260 & & SigB & SinR \\
\hline ydaM & general stress protein & & D068_31640 & & \\
\hline dnaJ & chaperone protein DnaJ & & D068_26020 & & $\mathrm{HrcA}$ \\
\hline$y d f O$ & $\begin{array}{l}\text { MhqO } \\
\text { glyoxalase/dioxygenase }\end{array}$ & & D068_29690 & SigB & MhqR \\
\hline ispF & $\begin{array}{l}\text { methylerythriol phosphate } \\
\text { pathway, lipid biosynthesis, } \\
\text { stress response }\end{array}$ & & D068_00770 & SigB & \\
\hline \multicolumn{6}{|c|}{ Transcriptional regulation } \\
\hline$y w a C$ & $\begin{array}{l}\text { SasA protein, stringent } \\
\text { response, } \mathrm{ppGpp} \\
\text { biosynthesis }\end{array}$ & D068_40690 & & SigM, SigW & \\
\hline perR & $\begin{array}{l}\text { peroxide stress regulator } \\
\text { PerR }\end{array}$ & D068_08620 & & & PerR \\
\hline spooA & $\begin{array}{l}\text { stage } 0 \text { sporulation two- } \\
\text { component response } \\
\text { regulator }\end{array}$ & D068_24730 & & SigH & Spo0A \\
\hline $\operatorname{lex} A$ & $\begin{array}{l}\text { LexA SOS-response } \\
\text { repressor }\end{array}$ & D068_19550 & & & LexA \\
\hline yozG & $\begin{array}{l}\text { Cro/Cl family transcriptional } \\
\text { regulator }\end{array}$ & D068_21840 & & & \\
\hline$y d e B$ & $\begin{array}{l}\text { CarD-like transcriptional } \\
\text { regulator }\end{array}$ & D068_03780 & & & \\
\hline ypdC & anti-sigW regulation & D068_23280 & & & \\
\hline$y t v A$ & $\begin{array}{l}\text { positive sigma-B regulator, } \\
\text { blue light GTP-binding }\end{array}$ & D068_30400 & & Spx & \\
\hline
\end{tabular}




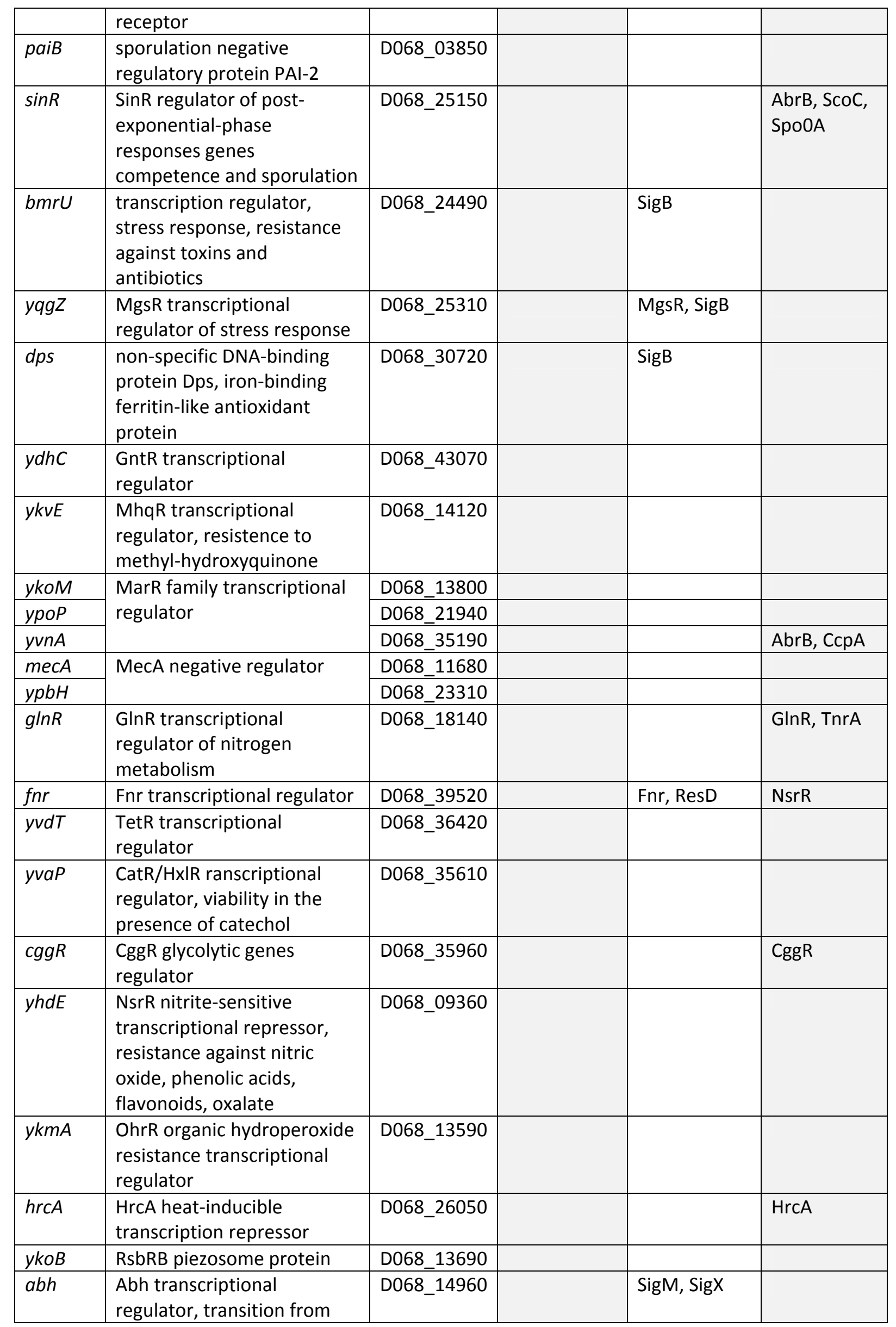




\begin{tabular}{|c|c|c|c|c|c|}
\hline & growth to stationary phase & & & & \\
\hline$y / b F$ & $\begin{array}{l}\text { ComK regulatory protein, } \\
\text { antagonist of biofilm } \\
\text { repression by } \operatorname{Sin} R\end{array}$ & D068_15530 & & & \\
\hline tnrA & $\begin{array}{l}\text { TnrA transcriptional } \\
\text { regulator, regulation of } \\
\text { nitrogen assimilation }\end{array}$ & D068_13790 & & TnrA & $G \ln R$ \\
\hline fur & $\begin{array}{l}\text { Fur regulation of iron } \\
\text { homoeostasis } \\
\text { By repression of } \\
\text { transcription of ferri- } \\
\text { siderophore uptake genes }\end{array}$ & D068_23940 & & PerR & \\
\hline zur & $\begin{array}{l}\text { Zur transcriptional regulator, } \\
\text { trace metal homeostasis }\end{array}$ & D068_25630 & & & \\
\hline$y j b D$ & Spx transcriptional regulator & D068_11660 & & $\begin{array}{l}\text { SigB, SigM, } \\
\text { SigW, SigX }\end{array}$ & PerR \\
\hline$x p f$ & $\begin{array}{l}\text { Xpf transcriptional regulator, } \\
\text { prophage transcription } \\
\text { activator }\end{array}$ & & D068_12870 & & ppGpp \\
\hline yvrL & $\begin{array}{l}\text { YvrL regulator, controls acid } \\
\text { stress proteins }\end{array}$ & & D068_35050 & $\begin{array}{l}\text { YvrHa, } \\
\text { YvrHb, Yvrl }\end{array}$ & \\
\hline \multicolumn{6}{|c|}{$\begin{array}{l}\text { Transport and uptake (in addition to mentioned above amino acid, } \\
\text { hydrocarbon and secondary metabolite transporters) }\end{array}$} \\
\hline \multirow[t]{2}{*}{ ypaA } & $\begin{array}{l}\text { RibU riboflavin ECF } \\
\text { transporter }\end{array}$ & D068_23390 & & & \\
\hline & siderophore Fe-uptake & D068_09870 & & & \\
\hline $\operatorname{expZ}$ & \multirow[t]{6}{*}{ ABC-transporters } & D068_34750 & & & \\
\hline yfiM & & & D068_08200 & & \\
\hline yfiL & & & D068_08190 & & \\
\hline yhcG & & & D068_09020 & & \\
\hline yvrO & & & D068_35100 & ComK & AbrB \\
\hline$y c l l$ & & & D068_32270 & YclJ & \\
\hline fhuG & \multirow{2}{*}{$\begin{array}{l}\text { ABC-type Fe3+-siderophore } \\
\text { transports }\end{array}$} & & D068_35130 & & Fur \\
\hline fhuB & & & D068_35140 & & Fur \\
\hline$y c d l$ & zinc $A B C$ transporter & & D068_02790 & & Zur \\
\hline $\operatorname{ssu} A$ & \multirow{2}{*}{$\begin{array}{l}\text { aliphatic sulfonate } A B C \\
\text { transporters }\end{array}$} & & D068_08760 & & CymR \\
\hline ssuC & & & D068_08770 & & CymR \\
\hline$y b b F$ & \multirow[t]{3}{*}{ PTS transporters } & & D068_01610 & & \\
\hline$m t / A$ & & & D068_32010 & & \\
\hline $\operatorname{sacP}$ & & & D068_40180 & & CcpA \\
\hline$a p p B$ & $\begin{array}{l}\text { OppB oligopeptide transport } \\
\text { system permease protein }\end{array}$ & & D068_11530 & & CodY, ScoC \\
\hline pstA & $\begin{array}{l}\text { PstA phosphate } \mathrm{ABC} \\
\text { transporter }\end{array}$ & & D068_25510 & PhoP & \\
\hline yqeW & $\begin{array}{l}\text { sodium-dependent } \\
\text { Nat/anion phosphate } \\
\text { transporter }\end{array}$ & & D068_25980 & & \\
\hline gltP & $\begin{array}{l}\text { proton/glutamate-aspartate } \\
\text { symport protein }\end{array}$ & & D068_02290 & & \\
\hline gltP & glycerol-3-phosphate & & D068_02100 & & CсpA \\
\hline
\end{tabular}




\begin{tabular}{|c|c|c|c|c|c|}
\hline & transporter & & & & \\
\hline$y c l F$ & di-/tripeptide transporter & & D068_32430 & & ScoC \\
\hline $\operatorname{dct} P$ & $\begin{array}{l}\text { aerobic C4-dicarboxylate } \\
\text { transporter for fumarate, L- } \\
\text { malate, D-malate and } \\
\text { succunate }\end{array}$ & & D068_31430 & & CсpA \\
\hline \multicolumn{6}{|c|}{ Other enzymes } \\
\hline & acetylxylan esterase & D068_19930 & & & \\
\hline tatCY & $\begin{array}{l}\text { R-CoA hydrolysis, twin- } \\
\text { arginine translocation } \\
\text { pathway }\end{array}$ & D068_13460 & & & \\
\hline ynet & succinyl-CoA synthetase & D068_19790 & & & \\
\hline$y f m J$ & putative oxidoreductase & & D068_07240 & Spo0A & \\
\hline$y x e L$ & putative acetyltransferase & & D068_32340 & & CymR \\
\hline yxeK & $\begin{array}{l}\text { nitrilotriacetate } \\
\text { monooxygenase }\end{array}$ & & D068_32350 & & CymR \\
\hline yurQ & $\begin{array}{l}\text { endo/excinuclease amino } \\
\text { terminal domain protein }\end{array}$ & & D068_34420 & & \\
\hline
\end{tabular}

*Information about gene repressors and activators was taken from SubtiWiki (http://subtiwiki.uni-goettingen.de/wiki/index.php/Main_Page) and DBTBS (http://dbtbs.hgc.jp/). 
Table S2. Operons of Bacillus atrophaeus UCMB-5137 regulated by maize root exudate differently from the patterns of stress response.

\begin{tabular}{|c|c|c|c|c|c|c|c|c|c|c|c|c|}
\hline \multirow{2}{*}{$\#$} & \multirow{2}{*}{ Operon and genes } & \multirow{2}{*}{$\begin{array}{l}\text { Orthologs in } \\
\text { Bs168 }\end{array}$} & \multirow{2}{*}{ Annotation } & \multicolumn{2}{|c|}{$\begin{array}{l}\text { Regulation by root } \\
\text { exudate }\end{array}$} & \multirow{2}{*}{ 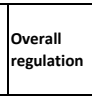 } & \multicolumn{4}{|c|}{ Regulation at stress conditions* } & \multicolumn{2}{|c|}{ TF } \\
\hline & & & & Fold Change & p-value & & $1.2 \mathrm{M}-\mathrm{NaCl}$ & $51^{\circ} \mathrm{C}$ & $\begin{array}{l}\text { Stationary } \\
\text { growth }\end{array}$ & $16^{\circ} \mathrm{C}$ & Known $^{\dagger}$ & Predicted $^{ \pm}$ \\
\hline \multicolumn{13}{|c|}{ 1: [cds_D068_00770; cds_D068_00760; cds_D068_00750] } \\
\hline & cds_D068_00770 & BSU00910 & $\begin{array}{l}\text { 2-C-methyl-D-erythritol 2,4- } \\
\text { cyclodiphosphate synthase EC 4.6.1.12 } \\
\text { 2-C-methyl-D-erythritol 4-phosphate }\end{array}$ & -30.77 & \multicolumn{2}{|c|}{ 4.27E-03 DOWN } & Not regulated & Not regulated & Not regulated & Not regulated & SigB, SigM & Degu, RocR \\
\hline & cds_D068_00760 & BSU00900 & cytidylyltransferase EC 2.7.7.60; & -1.36 & \multirow{2}{*}{\multicolumn{2}{|c|}{$\begin{array}{l}0.73 \\
0.81\end{array}$}} & & & & & & \\
\hline & cds_D068_00750 & BSU00890 & pilT; Pili retraction protein pilT; & -1.65 & & & & & & & & \\
\hline \multicolumn{13}{|c|}{ 2: [cds_D068_00800] } \\
\hline & cds_D068_00800 & BSU00930 & Serine acetyltransferase EC 2.3.1.30 & -8.42 & \multicolumn{2}{|c|}{ 2.47E-04 DOWN } & Not regulated & Not regulated & Not regulated & Not regulated & & \\
\hline \multicolumn{13}{|c|}{ 3: [cds_D068_01060; cds_D068_01050; cds_D068_01040; cds_D068_01030; cds_D068_01020] } \\
\hline & cds_D068_01060 & BSU01190 & LSU ribosomal protein L2p L8e & -4.57 & \multirow{2}{*}{\multicolumn{2}{|c|}{$\begin{array}{l}0.01 \text { DOWN } \\
0.09\end{array}$}} & Not regulated & Not regulated & Not regulated & Not regulated & Ywac & \\
\hline & cds_D068_01050 & BSU01180 & LSU ribosomal protein L23p L23Ae; & -3.14 & & & & & & & & \\
\hline & cds_D068_01040 & BSU01170 & LSU ribosomal protein L4p L1e; & -3.31 & \multirow{2}{*}{\multicolumn{2}{|c|}{$\begin{array}{l}0.08 \\
0.48\end{array}$}} & & & & & & \\
\hline & cds_D068_01030 & BSU01160 & LSU ribosomal protein L3p L3e; & -2.16 & & & & & & & & \\
\hline & cds_D068_01020 & BSU01150 & SSU ribosomal protein S10p S20e; & -1.85 & \multicolumn{2}{|c|}{0.78} & & & & & & \\
\hline
\end{tabular}

4: [cds_D068_01290]

$$
\begin{array}{lll}
\text { Cds_D068_01290 BSU01450 } & \begin{array}{l}
\text { ATPase component of general energizing } \\
\text { module of ECF transporters }
\end{array}
\end{array}
$$

$-4.81 \quad 5.07 E-03$ DOWN

Not regulated Not regulated Not regulated Not regulated

5: [cds_D068_01620; cds_D068_01630]

$$
\begin{array}{lll}
\text { cds_D068_01620 } & \text { BSU01690 } & \text { Sialic acid utilization regulator, RpiR family } \\
& \text { N-acetylmuramic acid 6-phosphate etherase } \\
\text { cds_D068_01630 } & \text { BSU01700 } & \text { EC 4.2.-.-; }
\end{array}
$$

6: [cds_D068_01790]

$$
\text { Cds_D068_01790 BSU01890 major facilitator MFS superfamily protein }
$$

7: [cds_D068_01970]

$$
\text { cds_D068_01970 }
$$

Lrga; Antiholin-like protein LrgA

$-19.93 \quad 0.02$ Down

\begin{tabular}{|c|c|c|}
\hline $\begin{array}{l}\text { cds_D068_02080 } \\
\text { cds_D068_02090 }\end{array}$ & BSUC & $\begin{array}{l}\text { Glycerophosphoryl diester } \\
\text { phosphodiesterase, periplasmic EC 3.1.4. } \\
\text { hypothetical protein; }\end{array}$ \\
\hline cds_DC & BSU02140 & Glycerol-3-phosphate transporter; \\
\hline \multicolumn{3}{|l|}{ 068_02130; cds_D } \\
\hline $\begin{array}{l}\text { Eds_D068_02130 } \\
\text { eds_D068_02140 }\end{array}$ & BSU02200 & $\begin{array}{l}\text { FIG01249079: hypothetical protein } \\
\text { hypothetical protein; }\end{array}$ \\
\hline
\end{tabular}

$-4.98 \quad 0.28$

$-50.76 \quad 0.03$ Down

0.03 Down

8: [cds_D068_02080; cds_D068_02090; cds_D068_02100]

10: [cds_D068_02290]

$\begin{array}{llll}\text { cds_D068_02290_BSU02340 } & \begin{array}{l}\text { Proton/glutamate symport protein @ } \\ \text { Proton/aspartate symport protein }\end{array} \text { inf }\end{array}$

11: [cds_D068_02410]

$$
\begin{array}{lll} 
& & \text { 5-dehydro-4-deoxyglucarate dehydratase EC } \\
\text { cds_D068_02410 BSU02460 } & \text { 4.2.1.41 }
\end{array}
$$

12: [cds_D068_02530; cds_D068_02520; cds_D068_02510]

$$
\begin{array}{lll}
\text { Cds_D068_02530 } & \text { BSU02570 } & \text { proctein } \\
\text { cds_D068_02520 } & \text { BSU02560 } & \text { sensor histidine kinase; } \\
\text { cds_D068_02510 } & \text { BSU02550 } & \text { DNA-binding response regulator; }
\end{array}
$$

13: [cds_D068_02690]

$$
\text { Cds_D068_02690 BSU02770 oxidoreductase, aldo/keto reductase family }
$$

14: [cds_D068_02790; cds_D068_02780]

$$
\begin{array}{rrl}
\text { cds_D068_02790 } & \text { BSU02860 } & \begin{array}{l}
\text { Znuc; Zinc ABC transporter, ATP-binding } \\
\text { protein ZnuC } \\
\text { znuA; Zninc ABC transporter, periplasmic- } \\
\text { binding protein ZnuA; }
\end{array} \\
\text { cds_D068_02780 } & \text { BSU02850 } &
\end{array}
$$

15.1: [cds_D068_02880; cds_D068_02870]

$$
\begin{array}{ll} 
& \text { COG0503: Adenine/guanine } \\
& \text { phosphoribosyltransferases and related } \\
\text { Cds_D068_02880 } & \text { PRPP-binding proteins } \\
\text { cds_D068_02870 } & \text { Citrate lyase beta chain EC 4.1.3.6; }
\end{array}
$$

15.2: [cds_D068_02860; cds_D068_02850; cds_D068_02840; cds_D068_02830]

$\begin{array}{lllll}\text { Cds_D068_02860 } & \text { BSU02920 } & \text { TerC-like integral membrane protein; } & -1.1 & 0.5 \\ \text { Cds_D068_02850 } & \text { BSU02910 } & \text { terDC; Tellurium resistance protein TerDC; } & -1.79 & 0.66 \\ \text { Cds_D068_02840 } & \text { BSU02900 } & \text { terDB; Tellurium resistance protein TerDB; } & -1.93 & 0.51 \\ \text { Cds_D068_02830 } & \text { BSU02890 } & \text { terDA; Tellurium resistance protein TerDA; } & -3.04 & 0.09\end{array}$

16: [cds_D068_03140]

$$
\begin{array}{lll}
\text { Cds_D068_03140 BSU03200 } & \begin{array}{l}
\text { Proline dehydrogenase EC 1.5.99.8 Proline } \\
\text { oxidase }
\end{array}
\end{array}
$$

17: [cds_D068_03270]

$$
\text { cds_D068_03270 BSU03330 Nitrate/nitrite transporter }
$$

18: [cds_D068_03520]

$$
\text { cds_D068_03520 }
$$

Surfactin synthetase SrfAA

19: [cds_D068_03660]

$$
\begin{array}{ll} 
& \begin{array}{l}
\text { 3-oxoacyl-acyl-carrier protein] reductase EC } \\
\text { 1.1.1.100; putative metabolite } \\
\text { dehydrogenase, NAD-binding; Possible } \\
\text { ortholog: BSn5_02410 from Bacillus subtilis }
\end{array}
\end{array}
$$

20: [cds_D068_03670]

$$
\begin{array}{cl} 
& \begin{array}{l}
\text { oxidoreductase, short-chain } \\
\text { dehydrogenase/reductase family; short- } \\
\text { chain dehydrogenase/reductase family; } \\
\text { Possible ortholog: GYO_0717 from Bacillus } \\
\text { subtilis }
\end{array}
\end{array}
$$

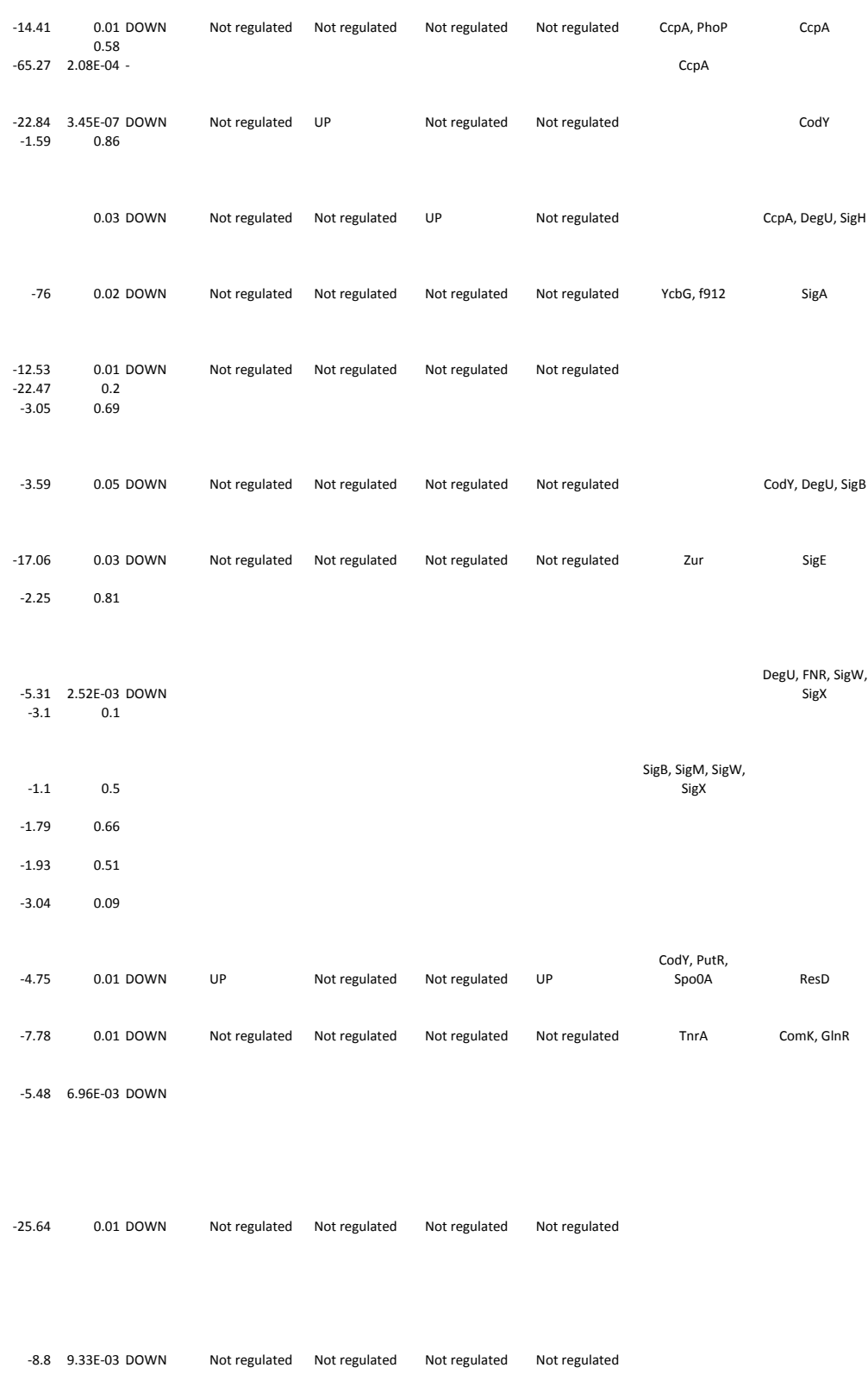


21: [cds_D068_04110; cds_D068_04100]

Emre; Ethidium bromide-methyl viologen

resistance protein EmrE; spermidine export

$\begin{array}{ll}\text { cds_D068_04110_BSU33570 } & \begin{array}{l}\text { protein mdtt; Possible ortholog: } \\ \text { BACAU_3793 from Bacillus }\end{array} \\ & \begin{array}{l}\text { Transcriptional regulator, TetR family; TetR } \\ \text { family transcriptional regulator; Possible }\end{array}\end{array}$

0.02 Down Not regulated Not regulated Not regulated Not regulated

cds_D068_04100_ortholog: BATR1942_06460 from Bacillus:

22: [cds_D068_04260]

Myo-inositol 2-dehydrogenase EC 1.1.1.1.18;
putative inositol 2-dehydrogenase; Possible
ortholog: BSUW23_02820 from Bacillus

23: [cds_D068_04790]

$\begin{array}{lll} & \begin{array}{l}\text { BSn5_14575; putative xre family } \\ \text { transcriptional; BSn5_14575; putative xre } \\ \text { family transcriptional }\end{array}\end{array}$

24: [cds_D068_04810]

Phage Rha protein; hypothetical protein;

cds_D068_04810 BSU20670 $\begin{aligned} & \begin{array}{l}\text { Possible ortholog: BSn5_14585 from Bacillus } \\ \text { subtilis }\end{array} \\ & \text { s. }\end{aligned}$

25: [cds_D068_04860; cds_D068_04850]

$\begin{array}{ll}\text { cds_D068_04860 } & \begin{array}{l}\text { hypothetical protein; Possible ortholog: } \\ \text { BAXH7_02364 from Bacillus } \\ \text { hypothetical protein; hypothetical 6.8Kb } \\ \text { protein; Possible ortholog: BSn5_14605 from }\end{array} \\ \text { cds_D068_04850 } & \text { Bacillus; }\end{array}$

cds_D068_04850

26: [cds_D068_04880]

unknown; LL3_00593; putative DNA-bindin
protein; skin; LL3_00593; putative DNA-

cds_D068_04880 BSU26270 binding protein; skin

27: [cds_D068_04890]

Dnac; DNA replication protein DnaC;
hypothetical protein; Possible ortholo:

$\begin{array}{lll}\text { cds_D068_04890 BSU12530 } & \text { hypothetical protein; Possible or } \\ \text { BAMTA208_11545 from Bacillus }\end{array}$

28: [cds_D068_04910]

cds_D068_04910

Hypothetical protein, Lmo2306 homolo

from Bacteriophage A118; hypothetical

protein; Possible ortholog: BSn5_14650 from

Bacillus subtil

$-36.63 \quad 4.40 E-03$ DOWN

29: [cds_D068_04940; cds_D068_04930; cds_D068_04920]

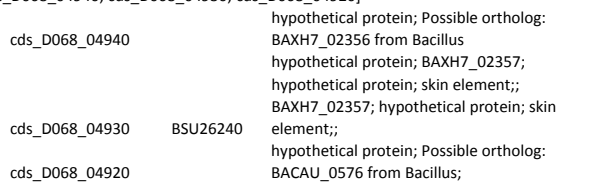

cds D068 04920

BACAU 0576 from Bacillus;

hypothetical protein; Uncharacterized

hypothetical protein; Uncharacterized
protein yqgA; Possible ortholog: BAMF_0572

cds_D068_05010

from Bacillus

inf

1.75E-03 DOWN

$\operatorname{CcpA}$

PurR, SigF

0.15

7.32E-10 DOWN

Phage terminase small subunit; hypothetic protein; Possible ortholog: BACAU_1835 from Bacillus

Phage tail length tape-measure protein;

$\begin{array}{lll}\text { Cds_D068_05220 BSU26030 } & \text { Yoml; Possible ortholog: BACAU_1821 from }\end{array}$

$-111.55 \quad 1.09 E-09$ DOWN

Not regulated Not regulated Not regulated Not regulated

PurR

FIG01237406: hypothetical protein; putative holin Lysis protein; Possible ortholog:

36: [cds_D068_05310]

cds_D068_05310 BSU25910 BACAU_0613 from Bacillus

2.59E-03 DOWN

Not regulated Not regulated Not regulated Not regulated

YeaB; Possible ortholog: BATR1942_00675

cds_D068_05950 BSU06320 from Bacillus
Cobalt-zinc-cadmium resistance protein;

hypothetical protein; unknown; unknown

$-17.18$

0.03 DOWN

$-31.58$

0.04 Down

0.05 Down

Not regulated Not regulated Not regulated Not regulated
CodY, RocR

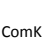

dY, LevR, Zur

gu, HrcA 
40: [cds_D068_06290]

\section{S-3-O-geranylgeranylglyceryl phosphate \\ synthase; geranylgeranylglyceryl phosphate \\ BATR1942 00830 from Bacillus}

$-9.75 \quad 7.69 \mathrm{E}-03$ DOWN

Not regulated Not regulated Not regulated Not regulated

41: [cds_D068_06670]

acetyltransferase, GNAT family; putative

$\begin{array}{ll}\text { cds_D068_06670 BSU06920 } & \text { acetyltransferase; Possible ortholog: } \\ \text { BATR1942_01045 from Bacillus }\end{array}$

0.03 Down

Not regulated Not regulated UP

UP

SigE, SpollII

42: [cds_D068_06760; cds_D068_06750; cds_D068_06740; cds_D068_06730]

Rhamnogalacturonides degradation prote RhiN; rhamnogalacturonan hydrolase;

$\begin{array}{ccl}\text { cds_D068_06760 BSU07000 } & \begin{array}{l}\text { Possible ortholog: BATR1942_01085 from } \\ \text { Bacillus } \\ \text { Predicted rhamnose oligosaccharide ABC }\end{array} \\ & \end{array}$ Predicted rhamnose oligosaccharide ABC
transport system, permease component: transport system, permease component;

$\begin{array}{lll}\text { cds_D068_06750 BSU06990 } & \begin{array}{l}\text { rhamnogalacturonan permease; Possible } \\ \text { ortholog: BATR1942_01080 from Bacillus; }\end{array}\end{array}$ Predicted rhamnose oligosaccharide ABC transport system, permease component 2; 0.04 Down Not regulated Not regulated Not regulated Not regulated

cds_D068_06740 BSU06980 $\begin{aligned} & \text { rhamnogalacturonan permease; Possible } \\ & \text { ortholog: BATR1942_01075 from Bacillus; }\end{aligned}$

Predicted rhamnose oligosaccharide ABC transport system, substrate-binding component; pectin degradation byproducts-

cds_D068_06730 BSU06970 $\quad \begin{aligned} & \text { binding lipoprotein; Possible orth } \\ & \text { BATR1942_01070 from Bacillus; }\end{aligned}$

43.2: [cds_D068_06830]

utative ion-channel protein

oxidoreductase, aldo/keto reductase family protein; Possible ortholog: BSUW23_13015

cds_D068_06830 BSU39780 from Bacillus

43.2: [cds_D068 06820; cds_D068_06810]

Predicted rhamnogalacturonan lyase in

$\begin{array}{lll} & \begin{array}{l}\text { rhamnose utilization cluster; polysaccharide } \\ \text { lyase; Possible ortholog: BATR1942_01115 } \\ \text { from Bacillus; }\end{array}\end{array}$ from Bacillus;

Predicted rhamnogalacturonan lyase in

rhamnose utilization cluster;

BATR1942_01110; polysaccharide lyase;

cds_D068_06810 BSU07050 $\begin{aligned} & \text { lipoprotein;; BATR1942 } \\ & \text { polysaccharide lyase;; }\end{aligned}$

44: [cds_D068_07090; cds_D068_07080]

UDP-glucose 4-epimerase EC 5.1.3.2; YfnG;

Possible ortholog: BATR1942_01235 from
ds_ D068_07090

$\begin{array}{ll}\text { Cds_D068_07090 BSU07280 } & \text { Bacillus } \\ & \text { Glucose-1-phosphate cytidylyltransferase EC }\end{array}$

Glucose-1-phosphate cytidylyttras
2.7.7.33; glucose-1-phosphate

$\begin{array}{lll}\text { cds_D068_07080 } & \text { BSU07270 } & \text { cytidylyltransferase; Possible ortholog: } \\ \text { BATR1942_01230 from Bacillus; }\end{array}$

6.74E-03 DOWN Not regulated Not regulated Not regulated Not regulated $\quad$ Sigk DegU, Sigk

0.09

45: [cds_D068_07240]

$\begin{array}{lll} & \begin{array}{l}\text { Yncb; Putative oxidoreductase YncB; } \\ \text { putative oxidoreductase; Possible ortholog: }\end{array} \\ \text { cds_D068_07240 BSU07450 } & \text { BATR1942_01325 from Bacillus }\end{array}$

46: [cds_D068_07360] Cita; Sensor kinase CitA, DpiB EC 2.7.3.; Cits;
Possible ortholog: BATR1942_01395 from

[cds_D068_07970; cds_D068_07960]

48: [cds_D068_08110]

FIG01252029: hypothetical protein;

Cds_D068_08110 BSU19030 hypothetical protein; Possible ortholog:

49: [cds_D068_08190]

ABC transporter, ATP-binding protein;

protein; Possible ortholog: BSn5_16035 from

cds_D068_08190 BSU08310 $\quad \begin{aligned} & \text { Bacillus subtilis } \\ & \text { Cas }\end{aligned}$

$-24.89 \quad 3.27 E-08$ DOWN

Not regulated Not regulated UP

Not regulated

7.93E-04 DOWN

Not regulated Not regulated Not regulated Not regulated

50: [cds_D068_08720]

Thic; Hydroxymethylpyrimidine phosphate synthase Thic; thiamine biosynthesis protein ThiC; Possible ortholog: BATR1942_01990

cds_D068_08720 BSU08790 from Bacillus

1: [cds_D068_08760; cds_D068_08750] Alkanesulfonates-binding protein; aliphatic
sulfonate $A B C$ transporter binding; Possible

cds_D068_08760_BSU08840 $\begin{aligned} & \text { sulfonate ABC transporter binding; Possible } \\ & \text { ortholog: BATR1942_02010 from Bacillus }\end{aligned}$

Alkanesulfonates ABC transporter ATP-

binding protein; aliphatic sulfonate $A B C$

$\begin{array}{lll}\text { cds_D068_08750 BSU08830 } & \text { transporter ATP-binding; Possible } \\ \text { BATR1942_02005 from Bacillus; }\end{array}$
$-34.94 \quad 9.81 E-03$ DOWN

Not regulated Not regulated Not regulated Not regulated 
52: [cds_D068_10330]

$$
\begin{array}{ll} 
& \begin{array}{l}
\text { Ribonuclease Z EC 3.1.26.11; putative metal- } \\
\text { dependent hydrolase; Possible ortholog: } \\
\text { BATR1942_02730 from Bacillus }
\end{array}
\end{array}
$$

53: [cds_D068_10380]

peptidase, M48 family; putative membrane
metalloprotease; Possible ortholog:

$\begin{array}{lll}\text { metalloprotease; Possible ortholo: } & \\ \text { cds_D068_10380 BSU10290 } & \text { BATR1942_02755 from Bacillus }\end{array}$

54: [cds_D068_11530; cds_D068_11520; cds_D068_11510; cds_D068_11500]

Oppb; Oligopeptide transport system

permease protein OppB TC 3.A.1.5.1; AppB;

Possible ortholog: BATR1942_03330 from

cds_D068_11530 BSU11390 $\quad$ Bacillus

oppA; Oligopeptide ABC transporter,

OppA TC 3.A.1.5.1. AppA; Possible ortholo

$\begin{array}{ll}\text { cds_D068_11520 BSU11380 } & \text { OppA TC 3.A.1.5.1; AppA; Possible ortholog; } \\ & \text { BATR1942_03325 from Bacillus; } \\ & \begin{array}{l}\text { oppF3; Oligopeptide transport ATP-binding } \\ \text { protein OppF TC 3.A.1.5.1; oligopeptide ABC }\end{array}\end{array}$ protein OppF TC 3.A.1.5.1; oligopeptide ABC
transporter ATP-binding protein; Possible

cds_D068_11510 BSU11370 $\begin{aligned} & \text { transporter ATP-binding protein; Possible } \\ & \text { ortholog: BATR1942_03320 from Bacillus; }\end{aligned}$

oppD3; Oligopeptide transport ATP-binding oppD3; Oligopeptide transport ATP-binding
protein OppD TC 3.A.1.5.1; oligopeptide ABC protein OpDD TC 3.A.1.1.5.1; oligopeptide ABC
transporter ATP-binding protein; Possible

cds_D068_11500 BSU11360 ortholog: BSn5_17590 from Bacillus subtilis;

55: [cds_D068_11550]

FIG01234419: hypothetical protein; putative

cds_D068_11550 BSU11410 ortholog: BATR1942_03340 from Bacillus

56: [cds_D068_11590; cds_D068_11580]

OppB1; Oligopeptide transport system

permease protein OppB TC 3.A.1.5.1;

$\begin{array}{lll} & \text { hypothetical protein; Possible ortholo } \\ \text { cds_D068_11590 BSU11440 } & \text { BATR1942_03355 from Bacillus }\end{array}$

oppA1; Oligopeptide ABC transporter,

periplasmic oligopeptide-binding prote

OppA TC 3.A.1.5.1; oligopeptide ABC

cds_D068_11580 BSU11430 $\begin{aligned} & \text { transporter binding lipoprotein; Possible } \\ & \text { ortholog: BATR1942_03350 from Bacillus; }\end{aligned}$

57: [cds_D068_11830; cds_D068_11820]

Thiamin-phosphate pyrophosphorylase EC 2.5.1.3; transcriptional regulator Tenl;

cds_D068_11830 BSU11660 $\begin{aligned} & \begin{array}{l}\text { Possible ortholog: BATR1942_03475 from } \\ \text { Bacillus }\end{array} \\ & \text { The }\end{aligned}$

Thiaminase II EC 3.5.99.2 involved in salvage of thiamin pyrimidine moiety; transcriptional

ds D068 11820 BSU11650 activator TenA; Possible ortholo

58: [cds_D068_12750]

59: [cds_D068_12820; cds_D068_12810]

N-acetylmuramoyl-L-alanine amidas

acetylmuramoyl-L-alanine amidase

BATR1942_03870; N-acetylmuramoy-

alanine

Xkdb; Phage-like element PBSX protein xkdB;
hypothetical protein; Possible ortholog:

$\begin{array}{ll}\text { cds_D068_12820 BSU12520 } & \text { BATR1942_03900 from Bacillus } \\ & \text { hypothetical protein; Possible ortholog: }\end{array}$

cds_D068_12810 BATR1942_03895 from Bacillus;

60: [cds_D068_12870]

RNA polymerase sigma-70 factor; positive

Cds D068_12870 control sigma-like factor; Possible ortholog:

61: [cds_D068_12880]

BATR1942_03930 from Bacillus

Phage terminase small subunit; PBSX

defective prophage terminase small subunit;

cds_D068_12880 BSU12570 $\begin{aligned} & \text { Possible } \\ & \text { Bacillus }\end{aligned}$

62: [cds_D068_13020]

Phage tail length tape-measure protein;
hypothetical protein; Possible ortholog:

$\begin{array}{lll}\text { Cds_D068_13020 BSU12680 } & \text { hypothetical protein; Possible or } \\ \text { BSU12680 from Bacillus subtilis }\end{array}$

63: [cds_D068_13420; cds_D068_13410; cds_D068_13400]

NLP/P60 family protein; cell wall

cds_D068_13420 BSU12990 $\begin{aligned} & \text { endopeptidase; Possible ortholo: } \\ & \text { BATR1942_04180 from Bacillus }\end{aligned}$

Muconate cycloisomerase EC 5.5.1.1; L-AlaD/L-Glu epimerase; Possible ortholog:

cds_D068_13410 BSU12980 D/L-Glu epimerase; Possible orth;

Muramoyltetrapeptide carboxypeptidase $\mathrm{EC}$ 3.4.17.13; putative L,D-carboxypeptidas Possible ortholog: BATR1942_04170 from

cds_D068_13400 BSU12970 Bacillus;

64: [cds_D068_14060; cds_D068_14050; cds_D068_14040]
-4.73 0.04 DowN Not regulated Not regulated Not regulated Not regulated
$-6.85 \quad 0.04$ DowN Not regulated Not regulated Not regulated UP CodY, ScoC

$1.05 \quad 0.23$

$-3.22 \quad 0.6$

$-4.55 \quad 0.49$
TnrA

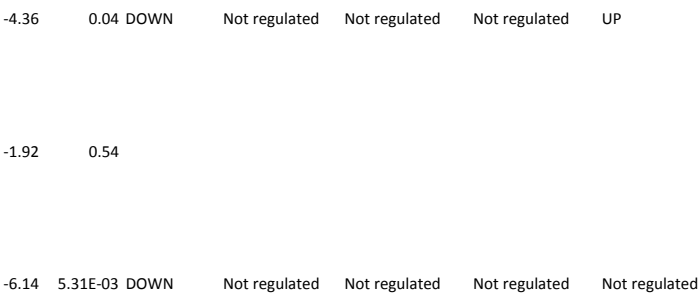




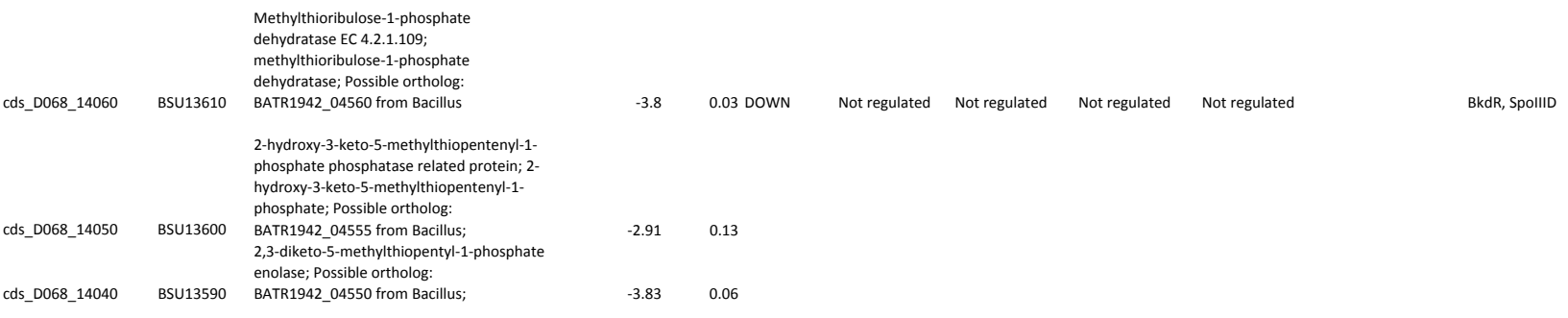

65: [cds_D068_14100; cds_D068_14090]

\begin{tabular}{|c|c|c|c|c|c|c|c|c|c|}
\hline cds_D068_14100 & BSU13650 & $\begin{array}{l}\text { small membrane protein; putative small } \\
\text { membrane protein; Possible ortholog: } \\
\text { BATR1942_04580 from Bacillus }\end{array}$ & $\inf$ & 0.05 DOWN & Not regulated & Not regulated & Not regulated & Not regulated & AbrB, Rok, SigB \\
\hline cds D068 14090 & BSU13640 & $\begin{array}{l}\text { Spo0E regulatory protein, specific } \\
\text { dephosphorylation of SpOAA-P stage } 0 \\
\text { sporulation; BATR1942_04575; negative } \\
\text { regulatory phosphatase; BATR1942_04575; } \\
\text { negative regulatory phosphatase; }\end{array}$ & inf & 0.11 & & & & & \\
\hline
\end{tabular}

66: [cds_D068_16310; cds_D068_16300; cds_D068_16290; cds_D068_16280; cds_D068_16270; cds_D068_16260; cds_D068_16250]

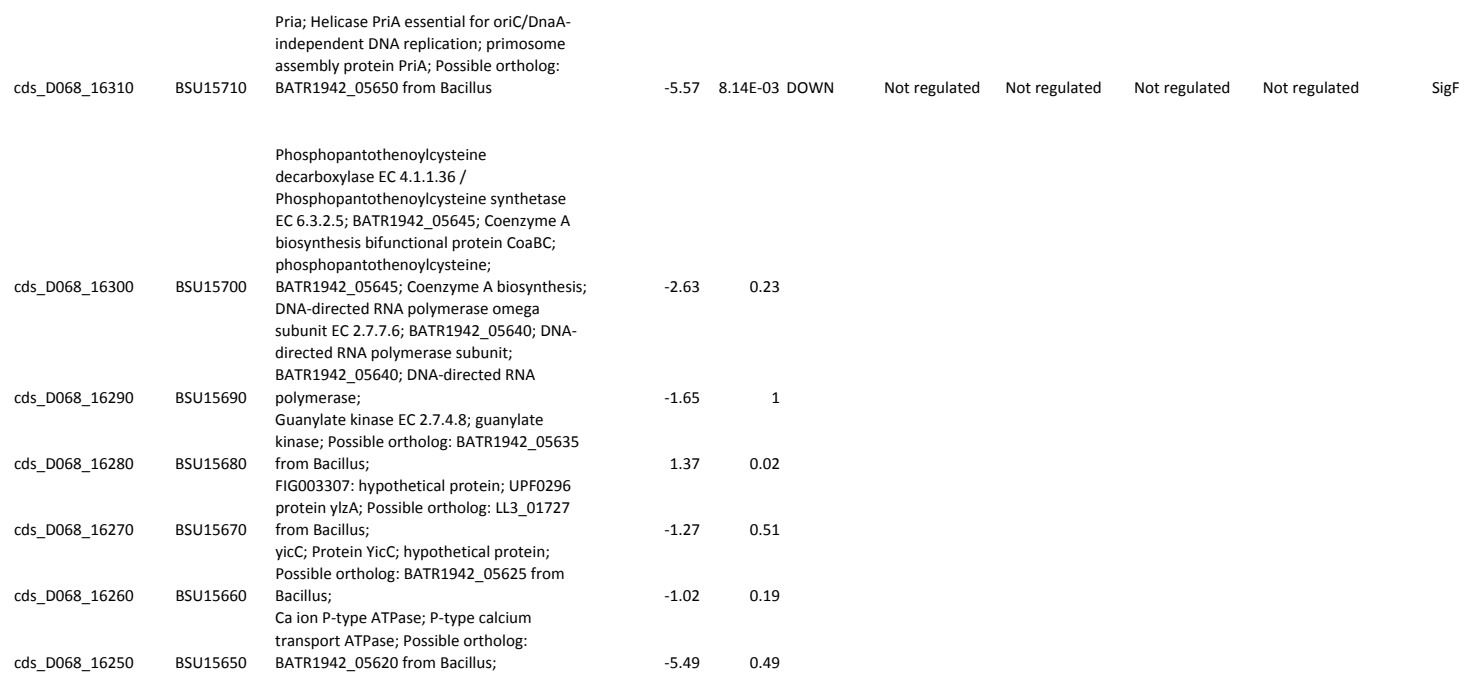

67: [cds_D068_16610] $\quad$ FIG01228237: hypothetical protein; YlqD;

$\begin{array}{lllllll}\text { cds_D068_16610 BSU16010 } & \begin{array}{l}\text { Possible ortholog: BATR1942_05795 from } \\ \text { Bacillus }\end{array} & -5.6 & 2.76 \mathrm{E}-03 \text { DOWN Not regulated Not regulated Not regulated Not regulated }\end{array}$

68: [cds_D068_16900; cds_D068_16890; cds_D068_16880; cds_D068_16870; cds_D068_16860; cds_D068_16850; cds_D068_16840; cds_D068_16830; cds_D068_16820; cds_D068_16810; cds_D068_16800; cds_D068_16790; cds_D068_16780]

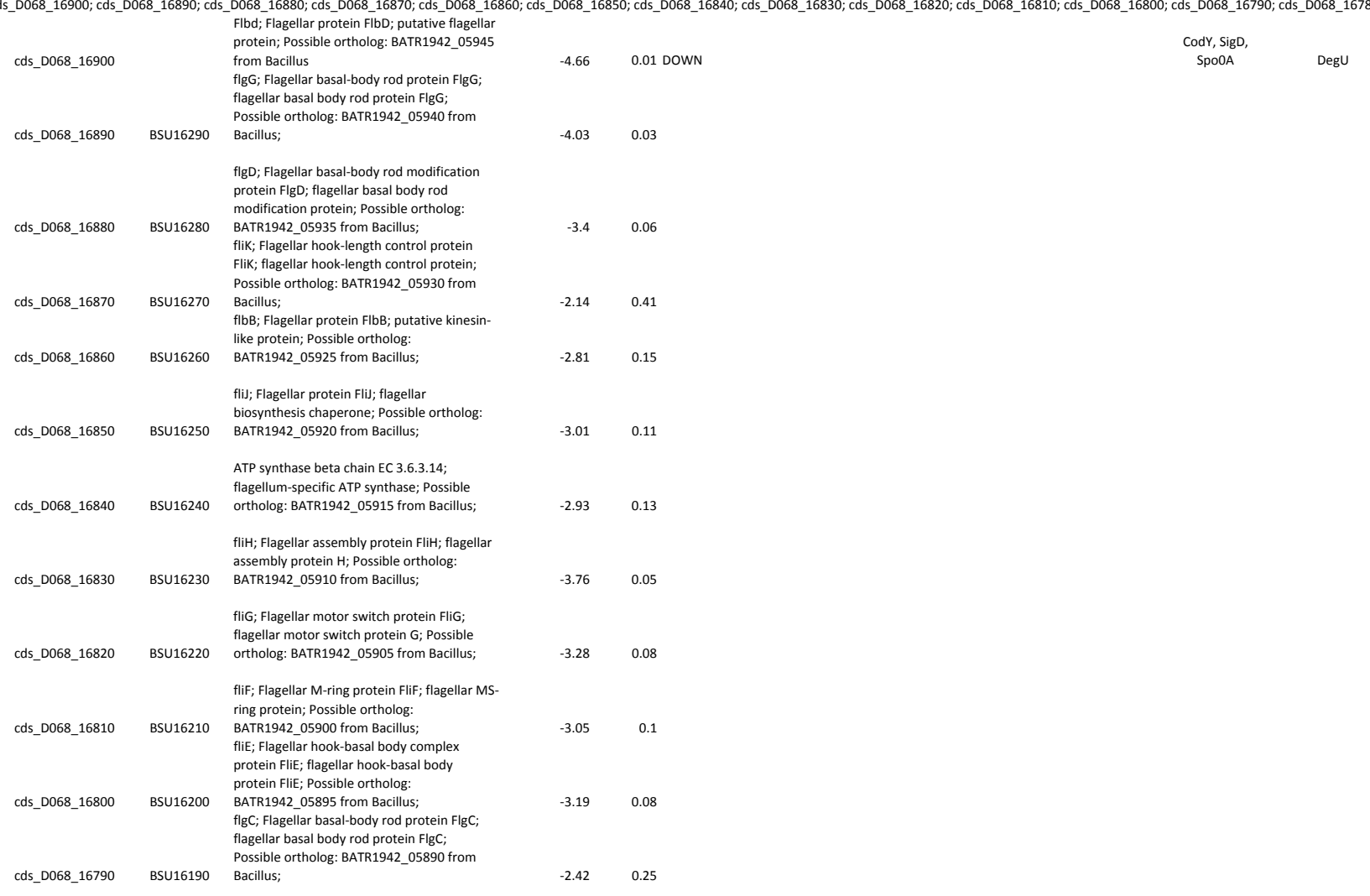




\section{flgB; Flagellar basal-body rod protein FlgB; flagellar basal body rod protein FlgB; \\ cds_0668_16780_BSU16180 Possible ortholog: BATR1942_05885 from}

69: [cds_D068_17140]

$\begin{array}{ll} & \begin{array}{l}\text { Undecaprenyl pyrophosphate synthetase EC } \\ \text { 2.5.1.31; undecaprenyl pyrophosphate } \\ \text { synthase; Possible ortholog: }\end{array} \\ \text { cds_D068_17140 BSTR1942_06065 from Bacillus }\end{array}$

2.5.1.31; undecaprenyl pyrophosphate

cds_D068_17140 BSU16530 BATR1942_06065 from Bacillus

70: [cds_D068_17220; cds_D068_17210; cds_D068_17200]

\begin{tabular}{|c|c|c|}
\hline & & $\begin{array}{l}\text { COG2740: Predicted nucleic-acid-binding } \\
\text { protein implicated in transcription } \\
\text { termination; YYXR; Possible ortholog: }\end{array}$ \\
\hline cds_D068_17220 & BSU16610 & $\begin{array}{l}\text { BATR1942_06110 fromBacillus } \\
\text { nusA; Transcription termination protein } \\
\text { NusA; transcription elongation factor NusA; } \\
\text { Possible ortholog: BATR1942_06105 from }\end{array}$ \\
\hline D068_17210 & BSU16600 & Bacillus; \\
\hline & & $\begin{array}{l}\text { COG0779: clustered with transcription } \\
\text { termination protein NusA; hypothetical } \\
\text { protein; Possible ortholog: BATR1942_061C } \\
\text { from Bacillus: }\end{array}$ \\
\hline
\end{tabular}

71: [cds_D068_17520; cds_D068_17510; cds_D068_17500]

CDP-diacylglycerol--glycerol-3-phosphate hosphatidyltransferase EC 2.7.8.5; CDPdiacylglycerol--glycerol-3-phosphate;

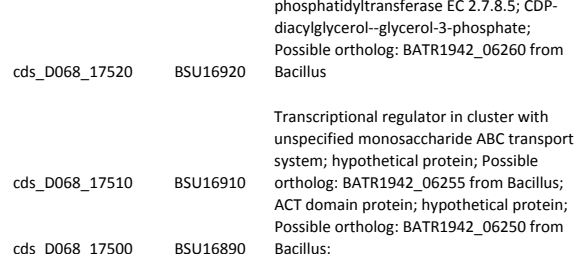

$-1.26 \quad 0.58$

-3.69 0.05 DowN Not regulated Not regulated Not regulated Not regulated

brB, GlnR, SigF

72: [cds_D068_17860; cds_D068_17850; cds_D068_17840; cds_D068_17830; cds_D068_17820; cds_D068_17810; cds_D068_17800]

\begin{tabular}{|c|c|c|}
\hline cds_D068_17860 & BSU17190 & $\begin{array}{l}\text { Bat2; polyketide synthase of type I; Possible } \\
\text { ortholog: BATR1942_06400 from Bacillus } \\
\text { bat1, Long-chain-fatty-acid--CoA ligase EC } \\
\text { 6.2.1.3; polyketide synthase of type I; }\end{array}$ \\
\hline \multirow[t]{2}{*}{ cds_D068_17850 } & BSU17180 & $\begin{array}{l}\text { Possible ortholog: BATR1942_06395 from } \\
\text { Bacillus; }\end{array}$ \\
\hline & & $\begin{array}{l}\text { batE; Enoyl-CoA hydratase EC 4.2.1.17; } \\
\text { polyketide biosynthesis enoyl-CoA } \\
\text { hydratase; Possible ortholog: }\end{array}$ \\
\hline \multirow[t]{2}{*}{ cds_D068_17840 } & BSU17170 & BATR1942_06390 from Bacillus; \\
\hline & & $\begin{array}{l}\text { batD; Methylglutaconyl-CoA hydratase EC } \\
\text { 4.2.1.18; polyketide biosynthesis enoyl-CoA } \\
\text { hydratase; Possible ortholog: }\end{array}$ \\
\hline \multirow[t]{2}{*}{ cds_D068_17830 } & BSU17160 & BATR1942_06385 from Bacillus; \\
\hline & & $\begin{array}{l}\text { batC; Hydroxymethylglutaryl-CoA synthase } \\
\text { EC 2.3.3.10; acetyl-S-AcpK beta- } \\
\text { ketothioester polyketide; Possible ortholog: }\end{array}$ \\
\hline cds_D068_17820 & BSU17150 & BATR1942_06380 from Bacillus; \\
\hline & & $\begin{array}{l}\text { batB; 3-oxoacyl-[acyl-carrier-protein] } \\
\text { synthase, KASII EC 2.3.1.41; polyketide beta }\end{array}$ \\
\hline cds_D068_17810 & BSU17140 & $\begin{array}{l}\text { ketoacyl:acyl carrier protein; Possible } \\
\text { ortholog: BATR1942_06375 from Bacillus; } \\
\text { batA; Acyl carrier protein; acyl carrier } \\
\text { protein; Possible ortholog: BATR1942 }\end{array}$ \\
\hline cds_D068_17800 & BSU17130 & from Bacillus; \\
\hline
\end{tabular}

73: [cds_D068_18000]

$\begin{array}{lll} & \text { unknown; YmaF; Possible ortholog: } \\ \text { Cds_D068_18000 BSU17320 } & \text { BATR1942_06470 from Bacillus }\end{array}$

74: [cds_D068_18410; cds_D068_18400]
$-2.03$

$1.54 \quad 0.98$

Not regulated Not regulated Not regulated Not regulated

$-1.33 \quad 0.59$

DNA polymerase IV EC 2.7.7.7; lesion bypass phage DNA polymerase; Possible ortholog: BAXH7_01248 from Bacillus
BAXH7_01247; hypothetical protein; phage Cds_D068_18410 BSU21500 $\begin{array}{ll} & \text { SPbeta;; BAXH7_01247; } \\ \text { cds_D068_18400 } & \text { protein; phage SPbeta }\end{array}$

75: [cds_D068_19950]

\section{Endo-1,4-beta-xylanase A precursor EC}

3.2.1.8; endo-1,4-beta-xylanase xylanase $D$ 3.2.1.8; endo-1,4-beta-xylanase xylanase
Possible ortholog: BATR1942_07120 from

cds_D068_19950 BSU18160 Bacillus AbrB
AbrB 76: [cds_D068_20095; cds_D068_20150a; cds_D068_20150]

$$
\begin{gathered}
\text { PlpC, Long-chain-fatty-acid-CoA ligase EC } \\
\text { cds_D068_20095 } \\
\begin{array}{c}
\text { cds_D068_20150a } \\
\text { cds_D068_20150 plipastatin synthetase }
\end{array}
\end{gathered}
$$

77: [cds_D068_20440; cds_D068_20450]

$$
\begin{array}{ll}
\text { cds_D068_20440 } & \begin{array}{l}
\text { hypothetical protein; Possible ortholog } \\
\text { BAXH7_02352 from Bacillus }
\end{array} \\
& \text { hypothetical protein; Possible ortholog } \\
\text { cds_D068_20450 } & \text { BSn5_14675 from Bacillus subtilis; }
\end{array}
$$

$-14.5 \quad 7.58 \mathrm{E}-03$ Down

$-4.55 \quad 0.03$ DOWN

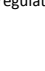

79: [cds_D068_21820] 
$\begin{array}{ll} & \text { Chitin binding protein; chitin binding } \\ \text { protein; Possible ortholog: BATR1942_08650 } & \text { from Bacillus }\end{array}$

80: [cds_D068_22820; cds_D068_22830]

FIG01227150: hypothetical protein; spore formation membrane associated protein: Possible ortholog: BATR1942 09130 from

$\begin{array}{lll}\text { cds_D068_22820 BSU22520 } & \begin{array}{l}\text { Possible ortholog: BATR1942_09130 fro } \\ \text { Bacillus } \\ \text { Hypothetical transmembrane protein }\end{array} \\ & & \text { CDS_ID OB1773; putative integrann }\end{array}$

CDS_ID OB1773; putative integral inner

$\begin{array}{lll}\text { cds_D068_22830 BSU22530 } & \text { membrane protein; Possible ort } \\ \text { BATR1942_09135 from Bacillus; }\end{array}$

81: [cds_D068_22850; cds_D068_22860]

Menaquinone-cytochrome c reductase, cytochrome B subunit; menaquinol-

cytochrome $c$ reductase cytochrome b

Possible ortholog: GYO_2482 from Bacillus

cds_D068_22850 BSU22550 $\quad \begin{aligned} & \text { Possibililis } \\ & \text { subtil }\end{aligned}$

Menaquinone-cytochrome $\mathrm{C}$ reductase ironsulfur subunit; menaquinol:cytochrome c sulfur subunit; menaquinol:cytochrome
oxidoreductase iron-sulfur; Possible

cds_D068_22860 BSU22560 oxidoreductase iron-sulfur; Possible

82: [cds_D068_23150; cds_D068_23160]

Glycerol-3-phosphate dehydrogenase

[NADP+] EC 1.1.1.94; NADPH-dependen

[NADP+] EC 1.1.1.94; NADPH-dependent
glycerol-3-phosphate; Possible ortholog

cds_D068_23150 BSU22830 BATR1942_09285 from Bacillus

engA; GTP-binding protein EngA; Possible

engA; GTP-binding protein EngA; Possible
ortholog: BATR1942_09290 from Bacillus;

83: [cds_D068_23980] from Bacillus

84: [cds_D068_24000] cds_D068_24000 BSU23580 Bacillus

-asparaginase EC 3.5.1.1; L-asparaginas Possible ortholog: BATR1942_10075 from

85: [cds_D068_24100; cds_D068_24110; cds_D068_24120]

FIG01230722: hypothetical protein;

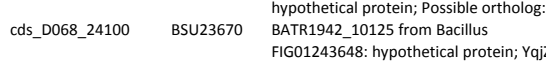
FIG01243648: hypothetical protein; Yqjz; Possible ortholog: RBAM_021810 from

cds_D068_24110 BSU23680 Bacillus;

vaj; YqjY; putative acetyltransferase;

86: [cds_D068_25110]

Aminomethyltransferase glycine cleavage

Aminomethyltransferase glycine cleava
system T protein EC 2.1.2.10; glycine

cleavage system aminomethyltransferase

cleavage system aminomethyltransferase $T_{\text {; }}$
Possible ortholog: BATR1942_10600 from

cds_D068_25110 BSU24570 Bacillus

87: [cds_D068_25510; cds_D068_25520; cds_D068_25530]

Psta; Phosphate transport system permease protein PstA TC 3.A.1.7.1; phosphate ABC

$\begin{array}{lll} & \text { transporter; Possible ortholog: } \\ \text { cds_D068_25510 } & \text { BSU24970 } & \text { BATR1942_10800 from Bacillus }\end{array}$

pstC; Phosphate transport system permeas protein PstC TC 3.A.1.7.1; phosphate ABC

$\begin{array}{lll} & \text { transporter permease; Possible ortholog: } \\ \text { cds_D068_25520 } & \text { BSU24980 } & \text { BATR1942_10805 from Bacillus; }\end{array}$

pstS; Phosphate ABC transporter

periplasmic phosphate-binding protein Psts

TC 3.A.1.7.1; phosphate ABC transporter

inding lipoprotein, Possible ortholog:

cds_D068_25530 BSU24990 BATR1942_10810 from Bacillus;

88: [cds_D068_25980]

Sodium-dependent phosphate transporter;

cds_D068_25980 BSU25420 $\begin{aligned} & \text { putative Nat/anion cotransporter; Possible } \\ & \text { ortholog: BATR1942_11020 from Bacillus }\end{aligned}$

89: [cds_D068_27630]

6-phospho-beta-glucosidase EC 3.2.1.8

cds D068 27630 BSU38560 hypothetical protein; Possible orth

90: [cds_D068_28250]

$\begin{array}{ll}\text { Ribonuclease PH EC 2.7.7.56; ribonuclease } & \\ \text { PH; Possible ortholog: BATR1942_11950 }\end{array}$

from Bacillus

91: [cds_D068_29160]

$\begin{array}{ll}\text { 6-phosphofructokinase EC 2.7.1.11; 6- } & \begin{array}{l}\text { phosphofructokinase; Possible ortholo } \\ \text { BATR1942_12380 from Bacillus }\end{array}\end{array}$

92: [cds_D068_29170; cds_D068_29180]

Acetyl-coenzyme A carboxyl transferas

alpha chain EC 6.4.1.2; acetyl-CoA

carboxylase carboxyltransferase subunit;

$\begin{array}{lll} & \begin{array}{l}\text { Possible } \\ \text { cds_D068_29170 BSU29200 }\end{array} & \text { Bacillus }\end{array}$
$-10.28 \quad 8.40 E-04$ DOWN

AbrB, SigA

01 DOWN Not regulated Not regulated Not regulated UP
$-21.04$

0.03 DOWN

Not regulated Not regulated UP

Not regulated AbrB, CcPA, ResD

$4.53 \quad 0.2$

0.05 Down

Not regulated Not regulated Not regulated Not regulated

Degu

$-2.06 \quad 0.58$

AnsR, CcpA

CcpA

$-3.33 \quad 0.05$ Down

Not regulated Not regulated Not regulated Not regulated

AnsR

$\begin{array}{ll}-4.21 & 0.02 \text { DOWN } \quad \text { UP }\end{array}$

Not regulated Not regulated Not regulated

0.04 Down

Not regulated Not regulated Not regulated Not regulated

PhoP

$-8.46 \quad 0.05$

1.65E-03 DOWN

Not regulated Not regulated Not regulated UP

0.03 Down

Not regulated Not regulated UP

Not regulated

CcpA, LicR

0.04 DOWN

Not regulated Not regulated Not regulated Not regulated

AhrC, LevR, SigH 


\section{Acetyl-coenzyme A carboxyl transferase beta \\ chain EC 6.4.1.2; acetyl-CoA carboxylase \\ cds D068_29180 BSU29210 subunit beta; Possible ortholog:}

93: [cds_D068_29590]

$\begin{array}{lll} & \begin{array}{l}\text { Non-heme chloroperoxidase EC 1.11.1.10; } \\ \text { bromoperoxidase; Possible ortholog: }\end{array} \\ \text { Cds_D068_29590 BSU10900 } & \text { BATR1942_12570 from Bacillus }\end{array}$

94: [cds_D068_29690]

$\begin{array}{cc}\text { Glyoxalase family protein; putative } \\ \text { cds_D068_29690 BSU05490 } & \begin{array}{l}\text { dioxygenase; Possible ortholog: } \\ \text { BATR1942_12615 from Bacillus }\end{array}\end{array}$

95: [cds_D068_30030; cds_D068_30040; cds_D068_30050]

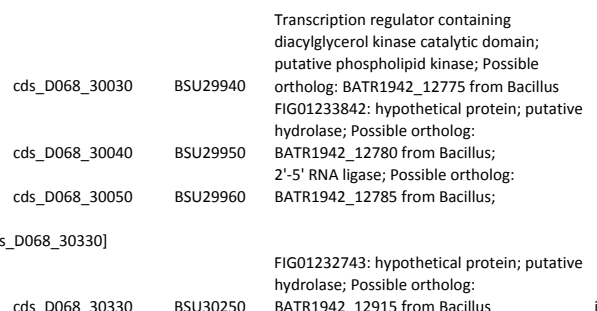

cds_D068 30330 BSU30250 BATR1942 12915 from Bacillus

97: [cds_D068_31080; cds_D068_31090]

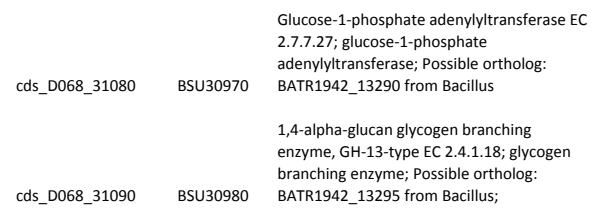

98: [cds_D068_31320; cds_D068_31330]

\begin{tabular}{|c|c|c|}
\hline As_D068_31320 & BSU04570 & $\begin{array}{l}\text { UDP-N-acetylmuramoylalanyl-D-glutamyl- } \\
\text { 2,6-diamino pimelate--D-alanyl-D-alanine } \\
\text { ligase EC 6.3.2.10; UDP-N-acetylmuramoyl- } \\
\text { tripeptide--D-alanyl-D- alanine; Possible } \\
\text { ortholog: BATR1942_21020 from Bacillus }\end{array}$ \\
\hline $068 \quad 31330$ & BSU04560 & $\begin{array}{l}\text { D-alanine--D-alanine ligase A EC 6.3.2.4; D- } \\
\text { alanyl-alanine synthetase A; Possible } \\
\text { ortholog: BATR1942 } 21015 \text { from Bacillus; }\end{array}$ \\
\hline
\end{tabular}

99: [cds_D068_31430]

$\begin{array}{cl} & \begin{array}{l}\text { Aerobic C4-dicarboxylate transporter for } \\ \text { fumarate, L-malate, D-malate, succunate; C4- } \\ \text { dicarboxylate transporter DctA; Possibile }\end{array} \\ \text { ortholog: BATR1942_20965 from Bacillus }\end{array}$

100: [cds_D068_31640; cds_D068_31650; cds_D068_31660; cds_D068_31670]

Elycosyl transferase, group 2 family protein putative glycosyltransferase associated to

\begin{tabular}{|c|c|c|}
\hline cds_D068_31640 & BSU04300 & $\begin{array}{l}\text { glycosyl transferase, group } 2 \text { family protein; } \\
\text { putative glycosyltransferase associated to } \\
\text { biofilm; Possible ortholog: BATR1942_20880 } \\
\text { from Bacillus }\end{array}$ \\
\hline & & $\begin{array}{l}\text { FIG01238801: hypothetical protein; } \\
\text { hypothetical protein; Possible ortholog: }\end{array}$ \\
\hline cds_D068_31650 & BSU04290 & BATR1942_20875 from Bacillus; \\
\hline cds_D068_31660 & BSU04280 & $\begin{array}{l}\text { GGDEF domain protein; putative membrane } \\
\text { protein with diguanylate cyclase; Possible } \\
\text { ortholog: BATR1942_20870 from Bacillus; }\end{array}$ \\
\hline s D D068 31 & BSU04270 & $\begin{array}{l}\text { FIG01227714: hypothetical protein; putative } \\
\text { glycosyl hydrolase lipoprotein; Possible } \\
\text { ortholog: BATR1942 } 20865 \text { from Bacillus; }\end{array}$ \\
\hline
\end{tabular}

101: [cds_D068_31750]

FIG01101636: hypothetical protein;
hypothetical protein; Possible ortholog:

cds_D068_31750 hypothetical protein; Possible ortholo:

102: [cds_D068_32010; cds_D068_32020]

$$
\begin{aligned}
& \text { PTS system, mannitol-specific IIA component } \\
& \begin{array}{l}
\text { EC 2.7.1.69; Mannitol-specific } \\
\text { phosphotransferase enzyme IIA; Possible }
\end{array} \\
& \text { cds_D068_32010 BSU03980 ortholog: BATR1942_20705 from Bacillus in } \\
& \begin{array}{l}
\text { PTS system, mannitol-specific IIB component } \\
\text { EC 2.7.1.69 / PTS system, mannitol-specific }
\end{array} \\
& \begin{array}{l}
\text { IIC component EC 2.7.1.69; hypothetical } \\
\text { II }
\end{array} \\
& \text { protein; Possible ortholog: BATR1942_20700 } \\
& \text { cds_D068_32020 BSU03980 from Bacillus; }
\end{aligned}
$$

$\begin{array}{lll}\text { cds_D068_32080 BSU03920 } & \begin{array}{l}\text { glucose uptake protein; GlcU; Possible } \\ \text { ortholog: BATR1942_20670 from Bacillus }\end{array} \text { in }\end{array}$

$\begin{array}{lll}\text { cds_D068_32080 BSU03920 } & \begin{array}{l}\text { glucose uptake protein; GlcU; Possible } \\ \text { ortholog: BATR1942_20670 from Bacillus }\end{array}\end{array}$

$\begin{array}{ll}-23.41 & 0.02 \text { DOWN } \\ & \\ -13.22 & 0.09\end{array}$

$1.15 \quad 0.07$

$-14.22 \quad 0.03$ Down

$$
\begin{aligned}
& \begin{array}{ll} 
& \text { ABC transporter, permease protein; } \\
& \text { hypothetical protein; Possible ortholog: } \\
\text { cds_D068_32270 BSU03740 } & \text { BSU03740 from Bacillus subtilis }
\end{array} \\
& \text { cds_D068_32260 }
\end{aligned}
$$




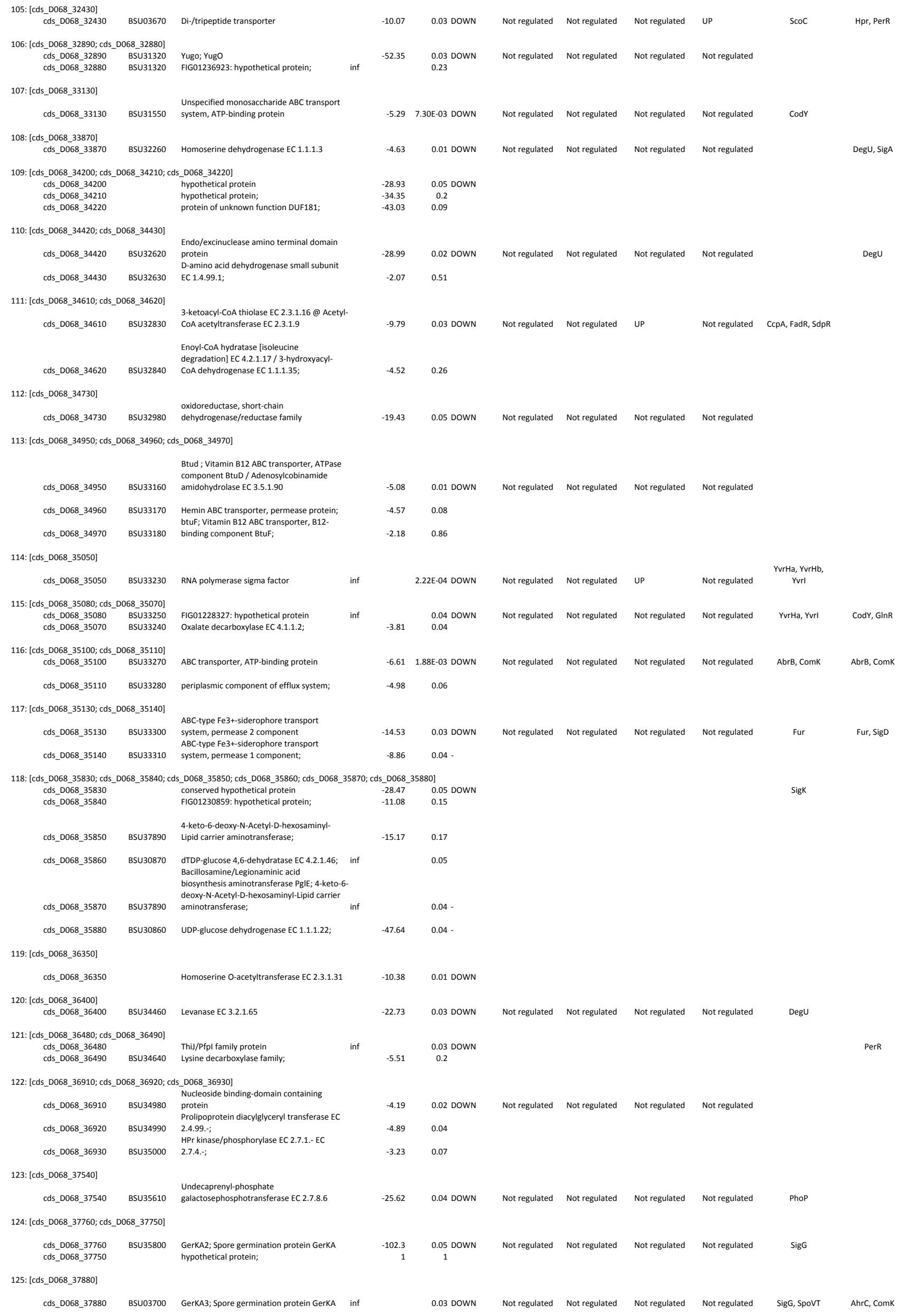

126: [cds_D068_38300; cds_D068_38310; cds_D068_38320] 


$$
\begin{aligned}
& \text { Manganese-dependent protein-tyrosine } \\
& \begin{array}{lll}
\text { cds_D068_38300 BSU36240 } & \begin{array}{l}
\text { phosphatase EC 3.1.3.48 } \\
\text { epsD ; Tyrosine-protein kinase EpsD EC }
\end{array}
\end{array} \\
& \text { cds_D068_38310 } \\
& \text { cds_D068_38320 }
\end{aligned}
$$

127: [cds_D068_38340]

$$
\text { cds_D068_38340 BSU36270 FIG01230320: hypothetical protein }
$$

128: [cds_D068_38500; cds_D068_38490]

cds D068 $38500 \quad$ BSU36450 major facilitator family transporter

cds_D068_38490 BSU36440 Transcriptional regulator, MarR family;

129: [cds_D068_38680; cds_D068_38670; cds_D068_38660; cds_D068_38650; cds_D068_38640]

$$
\begin{aligned}
& \text { cds_D068_38680 BSU37850 } \begin{array}{ll}
\text { Pseudaminic acid cytidylyltransferase EC } \\
2.7 .7 .43
\end{array} \\
& \begin{array}{l}
2.7 .7 .43 \\
\text { spsF; Spore coat polysaccharide biosynthesis }
\end{array} \\
& \text { protein spsF; } \\
& \text { PgIE; Bacillosamine/Legionaminic acid } \\
& \text { biosynthesis aminotransferase PgIE; 4-keto- } 6 \text { - } \\
& \text { deoxy-N-Acetyl-D-hexosaminyl-Lipid carrier }
\end{aligned}
$$

$\begin{array}{lll}\text { cds_D068_38650 } & \text { BSU37830 } & \text { UDinotransfucose 4-epimerase EC 5.1.3.2; }\end{array}$

$$
\begin{array}{ll}
-9.21 & 7.12 \mathrm{E}-03 \text { DOWN } \\
-8.14 & 0.03- \\
-2.83 & 0.49 \\
& \\
-6.96 & 0.01 \text { DOWN } \\
& \\
-4.23 & 0.04 \text { DOWN }
\end{array}
$$$$
-9.21 \quad 7.12 \mathrm{E}-03
$$$$
-2.83 \quad 0.49
$$$$
\text { Not regulated Not regulated Not regulated Not regulated }
$$$$
\begin{array}{rr}
-1.79 & 0.89
\end{array}
$$

$-24.76$

$-10.31$

0.01 Down

0.08

$\begin{array}{rr}-6.34 & 0.16 \\ -10.52 & 0.14\end{array}$

130: [cds_D068_38780; cds_D068_38790]

$\begin{array}{lll}\text { Cds_D068_38780 } & \text { BSU36650 } & \text { Urease beta subunit EC 3.5.1.5 } \\ \text { Cds_D068_38790 } & \text { BSU36660 } & \text { Urease gamma subunit EC 3.5.1.5; }\end{array}$

131: [cds_D068_39120]

$$
\begin{array}{cll}
\text { Yrdc; YrdC/Sua5 family protein, required for } \\
\text { threonylcarbamoyladenosine t6A formation }
\end{array}
$$

132: [cds_D068_39480]

$$
\begin{array}{lll} 
& \multicolumn{1}{l}{\text { Respiratory nitrate reductase alpha chain EC }} \\
\text { cds_D068_39480 BSU37280 } & \begin{array}{l}
1.7 .99 .4
\end{array}
\end{array}
$$

133: [cds_D068_39950]

$$
\begin{array}{lll}
\text { Cds_D068_39950] } & \text { BSU37750 FIG01240693: hypothetical protein } & \text { inf }
\end{array}
$$

134: [cds_D068_40170; cds_D068_40180; cds_D068_40190]

$$
\begin{array}{lll}
\text { cds_D068_40170 } & \text { BSU38040 } & \text { Sucrose-6-phosphate hydrolase EC 3.2.1.26 } \\
& & \begin{array}{l}
\text { PTS system, sucrose-specific IIB component } \\
\text { EC 2.7.1.69/PTS system, sucrose-specific IIC }
\end{array} \\
\text { cds_D068_40180 } & \text { BSU38050 } & \begin{array}{l}
\text { component EC 2.7.1.69; } \\
\text { hypothetical protein; }
\end{array}
\end{array}
$$

135: [cds_D068_40930; cds_D068_40940]

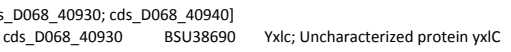

cds_D068_40940 BSU38700

xlc; Uncharacterized protein yxlc

(a) sigma-70 factor

136: [cds_D068_41580]

cds_D068_41580 BSU18650 Pectin lyase EC 4.2.2.10 inf

137: [cds_D068_41670; cds_D068_41680]

$$
\text { cds_D068_41670 BSU39260 }
$$

Beta-glucosidase EC 3.2.1.21; 6-phospho-

cds_D068_41670 BSU39260 beta-glucosidase EC 3.2.1.86

PTS system, beta-glucoside-specific IIIB

component EC 2.7.1.69 / PTS system, beta-

glucoside-specific IIC component EC 2.7.1.69

/PTs system, beta-glucoside-specific IIA
cds_D068_41680 BSU39270
component EC 2.7.1.69;

138: [cds_D068_41700; cds_D068_41710; cds_D068_41720; cds_D068_41730]

$$
\begin{aligned}
& \begin{array}{l}
\text { _ds_D068_41700_D } \\
\text { cds_4 }
\end{array} \\
& \text { cds_D068_41710 BSU37740 FIG01225345: hypothetical protein; } \\
& \text { cds_D068_41720 BSU37710 FIG01233033: hypothetical protein; } \\
& \begin{array}{lll}
\text { cds_D068_41730 } & \text { BSU18770 } & \begin{array}{l}
\text { Permease of the drug/metabolite } \\
\text { transporter DMT superfamily; }
\end{array}
\end{array}
\end{aligned}
$$

139: [cds_D068_41790; cds_D068_41780]

cds_D068_41790_BSU39360 Urocanate hydratase EC 4.2.1.49



140: [cds_D068_42000; cds_D068_42010; cds_D068_42020]

$\begin{array}{lll}\text { cds_D068_42000 } & \text { BSU39620 } & \text { DUF1093 domain-containing protein } \\ & \text { yvcS2; ABC transporter permease protein } \\ \text { cds_D068_42010 } & \text { BSU39630 } & \text { YvcS; } \\ & \text { yvcR2; ABC transporter ATP-binding protein } \\ \text { cds_D068_42020 } & \text { BSU39640 } & \text { YvcR; }\end{array}$

\section{$-7.07 \quad 2.32 \mathrm{E}-03$ DOWN}

$-6.55 \quad 0.01-$

$-4.85$

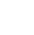

0.04 Down

Not regulated Not regulated UP

\begin{tabular}{|c|c|c|c|c|c|c|c|c|c|c|}
\hline cds_D068_42080 & BSU39680 & $\begin{array}{l}\text { Inosose isomerase EC 5.3.99.- } \\
\text { Glyceraldehyde-3-phosphate ketol- }\end{array}$ & -29.99 & 0.03 DOWN & Not regulated & Not regulated & Not regulated & Not regulated & CcpA, IOIR & $\mathrm{CcpA}$ \\
\hline cds_D068_42090 & BSU39690 & isomerase EC 5.3.1.1; & -4.86 & 0.44 & & & & & & \\
\hline cds_D068_42100 & BSU39700 & Myo-inositol 2-dehydrogenase 1 EC 1.1.1.18; & -5.26 & 0.2 & & & & & & \\
\hline cds_D068_42110 & BSU39710 & iolF; Minor myo-inositol transporter lolF; & -8.49 & 0.03 - & & & & & & \\
\hline cds_D068_42120 & BSU39720 & Inosose dehydratase EC 4.2.1.44; & -3.53 & 0.18 & & & & & & \\
\hline cds_D068_42130 & BSU39730 & Epi-inositol hydrolase EC 3.7.1.-; & -4.62 & 0.14 & & & & & & \\
\hline cds_D068_42140 & BSU39740 & 5-keto-2-deoxygluconokinase EC 2.7.1.92; & -4.65 & 0.14 & & & & & & \\
\hline cds_D068_42150 & BSU39750 & $\begin{array}{l}\text { 5-deoxy-glucuronate isomerase EC 5.3.1.-; } \\
\text { Methylmalonate-semialdehyde } \\
\text { dehydrogenase, inositol metabolism EC }\end{array}$ & -3.24 & 0.31 & & & & & & \\
\hline cds_D068_42160 & BSU39760 & 1.2.1.27; & -1.63 & 0.89 & & & & & & \\
\hline \multicolumn{11}{|l|}{ s_D068_42360; cds_ } \\
\hline cds_D068_42360 & BSU40040 & Glycerate kinase EC 2.7.1.31 & -5.69 & 0.02 Down & Not regulated & Not regulated & Not regulated & Not regulated & AbrB & \\
\hline cds_D068_42370 & & D-glycerate transporter predicted; & -9.58 & 0.08 & & & & & & \\
\hline $\begin{array}{l}\text { dds_Do68__24 } \\
\text { cds D068 } 42470\end{array}$ & BSU05620 & D-serine/D-alanine/glycine transporter & & 0.02 DOWN & Not regulated & Not regulated & Not regulated & Not regulated & & Sijot \\
\hline
\end{tabular}

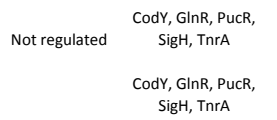

$\mathrm{SigH}, \mathrm{TnrA}$

Degu

NR, SigW

Not regulated Not regulated Not regulated UP

$1 \begin{array}{r}2.66 \mathrm{E}-03 \\ \quad 1\end{array}$

$-2.58 \quad 0.46$

0.03 Down

0.05 Down

Not regulated Not regulated UP

Not regulate

CcpA

CcpA

$\begin{array}{ll}-7.95 & 0.07\end{array}$

$-2.57 \quad 0.23$

$-6.11 \quad 8.48 \mathrm{E}-04-$

$\begin{array}{rr}-45.16 & 0.02 \\ -38.59 & 0.06\end{array}$

06

0.04 Down

Not regulated Not regulated UP

Not regulated

CcpA, $\operatorname{cod} Y$



$-6.71 \quad 0.08$
-0.00

$\begin{array}{ll}-8.62 & 0.25\end{array}$

141: [cds_D068_42080; cds_D068_42090; cds_D068_42100; cds_D068_42110; cds_D068_42120; cds_D068_42130; cds_D068_42140; cds_D068_42150; cds_D068_42160] 
144: [cds_D068_42630] cds_D068_42630

BSU40280 unknown
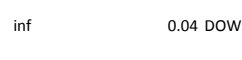

Notra

Not regulated Not regulated UP

Not regulated

Phop

DegU

Cds_D068_42660 BSU40330 Roce; Arginine permease RocE

$-3.76$

$-4.45 \quad 9.66 \mathrm{E}-03$ DOWN

$\begin{array}{rr}-2.76 & 0.38 \\ -23.9 & 0.14\end{array}$

$-57.7 \quad 0.02-$

$-38.24 \quad 0.02$ DOWN

Not regulated Not regulated Not regulated UP

SigE

$21.43 \quad 6.23 \mathrm{E}-03$ DowN Not regulated Not regulated Not regulated Not regulated

cds_D068_43370

Anaerobic dehydrogenases, typically

selenocysteine-containing
FIG001891: protein involved in chromosome

$2.17 \quad 3.74 \mathrm{E}-04$ UP

cds_D068_00020

BSU00020 DNA polymerase III beta subunit EC 2.7.7.7

150: [cds_D068_01940]

$$
\text { cds_D068_01940_BSU33400 } \begin{aligned}
& \begin{array}{l}
\text { oxidoreductase of aldo/keto reductase } \\
\text { family, subgroup 1 }
\end{array} \\
& \text {. }
\end{aligned}
$$

151: [cds_D068_03770]

cds_D068_03770

Cspa; Cold shock protein Cspi;

protein; Possible ortholog: BATR1942_00145

152: [cds_D068_04680]

$\begin{array}{cl} & \begin{array}{l}\text { Moac; Molybdenum cofactor biosynthesis } \\ \text { protein MoaC; molybdenum cofactor } \\ \text { biosynthesis protein MoaC; Possible } \\ \text { ortholog: BATR1942_00500 from Bacillus }\end{array}\end{array}$

153: [cds_D068_04730]

$\begin{array}{lll} & \begin{array}{l}\text { protein; putative membrane protease; } \\ \text { Possible ortholog: BATR1942_00525 from } \\ \text { cds_D068_04730 BSU06010 } \\ \text { Bacillus }\end{array}\end{array}$

154: [cds_D068_05350]

$$
\begin{array}{ll}
\text { hypothetical protein; Possible ortholog: } \\
\text { cds_D068_05350 }
\end{array}
$$

155: [cds_D068_05370]

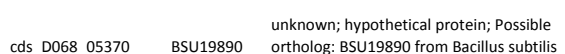

156: [cds_D068_05910]

$\begin{array}{lll} & \begin{array}{l}\text { Yeaa; conserved protein YeaA; hypothetical } \\ \text { protein; Possible ortholog: BATR1942_00655 } \\ \text { from Bacillus }\end{array}\end{array}$

157: [cds_D068_07460]

$$
\begin{aligned}
& \text { FIG01242431: hypothetical protein; } \\
& \text { hypothetical protein; Possible ortholo }
\end{aligned}
$$

$\begin{array}{ll}\text { hypothetical protein; Possible ortholo: } & \\ \text { cds_D068_07460 BSU07680 } & \text { BATR1942_01445 from Bacillus }\end{array}$

158: [cds_D068_07470]

Methionine aminopeptidase EC 3.4.11.18;

cds_D068_07470 BSU07690 $\begin{aligned} & \text { methionine aminopeptidase; Possible } \\ & \text { ortholog: BATR1942_01450 from Bacillus }\end{aligned}$

159: [cds_D068_08500]

$\begin{array}{lll} & \begin{array}{l}\text { Hypothetical protein SAV1869; YfhP; } \\ \text { Possible ortholog: BATR1942_01880 from } \\ \text { Bacillus }\end{array}\end{array}$

160: [cds_D068_08570]

Cysteinyl-tRNA synthetase related protein

hypothetical protein; Possible ortholog:

161: [cds_D068_08620]

Perr; Peroxide stress regulator PerR, FUR

$\begin{array}{lrl} & \begin{array}{l}\text { Perr; Peroxide stress regulator: } \\ \text { family; PerR; Possible ortholog: } \\ \text { cds_D068_08620 BSU08730 } \\ \text { BATR1942_01940 from Bacillus }\end{array}\end{array}$

162: [cds_D068_08690; cds_D068_08700]

Spore coat protein F; putative spore coat
protein; Possible ortholog: BATR1942 01975

from Bacillus; overlaps CDS with the same

cds_D068_08690 BSU26950 $\begin{aligned} & \text { from Bacillus; overlaps CDS with the same } \\ & \text { product name, possible frameshift mutation; inf }\end{aligned}$

163: [cds_D068_09280]

$$
\begin{array}{cl} 
& \begin{array}{l}
\text { Aerobic glycerol-3-phosphate } \\
\text { dehydrogenase EC 1.1.5.3; glycerol-3- } \\
\text { phosphate dehydrogenase; Possible } \\
\text { ortholog: BATR1942_02250 from Bacillus }
\end{array}
\end{array}
$$

164: [cds_D068_09360]

Nsrr; Nitrite-sensitive transcriptional

repressor NsrR; NO-dependent activator of

$\begin{array}{lll} & \text { the ResDE regulon; Possible orthol } \\ \text { cds_D068_09360 BSU09380 } & \text { BATR1942_02290 from Bacillus }\end{array}$

Not regulated Not regulated Not regulated Not regulated

$2.1 \quad 3.72 \mathrm{E}-03$ UP

Not regulated Not regulated Not regulated Not regulated

$3.82 \quad 2.80 \mathrm{E}-05$ UP

$3.02 \quad 0$ UP

Not regulated Not regulated Not regulated Not regulated 
Hypothetical protein SAV1845; hypothetical protein; Possible ortholog: BATR1942_02520 Cds_D068_09830 BSU09800 from Bacillus

Hypothetical protein SAV1846; hypothetical cds_D068 09820 protein; Possible ortholog: BATR1942_02515

166: [cds_D068_09870]

\section{cds_D068_09870}

Siderophore biosynthesis protein

monooxygenase; putative lysine/ornithine $\mathrm{N}$ monooxygenase; Possible ortholog: BATR1942_02540 from Bacillus

167: [cds_D068_10010; cds_D068_10020]

$\begin{array}{ll} & \text { FIG01227217: hypothetical protein; } \\ \text { hypothetical protein; Possible ortholog: } & \text { BATR1942_02605 from Bacillus } \\ \text { Cds_D068_10010 } & \begin{array}{l}\text { Hypothetical protein SAV1840; putative } \\ \text { bacteriocin; Possible ortholog: }\end{array} \\ \text { cds_D068_10020 BSU09960 } & \text { BATR1942_02610 from Bacillus; }\end{array}$

168: [cds_D068_10450]

$$
\begin{array}{ll}
\text { Predicted broad substrate specificity } \\
\text { phosphatase; phosphatase; Possible } \\
\text { ortholog: BATR1942_02790 from Bacillus }
\end{array}
$$

169: [cds_D068_11280; cds_D068_11270]

$$
\begin{aligned}
& \text { probably aromatic ring hydroxylating } \\
& \text { enzyme, evidenced by COGnitor; PaaD-like } \\
& \begin{array}{cc} 
& \begin{array}{l}
\text { protein DUF59 involved in Fe-S cluster } \\
\text { assembly; hypothetical protein; Possible } \\
\text { ortholog: BATR1942_03205 from Bacillus }
\end{array}
\end{array} \\
& \text { Putative hydrolase of the alpha/beta } \\
& \text { cds_D068_11270 BSU11150 } \begin{array}{l}
\text { superfamily; putative hydrolase; Possible } \\
\text { ortholog: BATR1942_03200 from Bacillus; }
\end{array}
\end{aligned}
$$

170: [cds_D068_11660]

$$
\begin{array}{ccc}
\text { Arsenate reductase family protein; } & \begin{array}{l}
\text { transcriptional regulator Spx; Possible } \\
\text { ortholog: BAXH7_02421 from Bacillus }
\end{array}
\end{array}
$$

171: [cds_D068_11680]

$$
\begin{array}{ll}
\text { Meca; Negative regulator of genetic } \\
\text { competence MecA; adaptor protein; Possible } \\
\text { ortholog: BATR1942_03400 from Bacillus }
\end{array}
$$

172: [cds_D068_11720; cds_D068_11730]

$$
\text { YjbH-like, GTP pyrophosphokinase domain; }
$$

YjbH; Possible ortholog: BATR1942 03420 from Bacillus

hbO; Hemoglobin-like protein HbO; putative thiol management oxidoreductase

$\begin{array}{lll}\text { cds_D068_11730 } & \text { BSU11560 } & \text { BATR1942_03425 from Bacillus; }\end{array}$

173: [cds_D068_12440]

Yjgb; Uncharacterized protein yjgB

cds D068_12440 BSU12150 precursor; YjgB; Possible ortholo:

174: [cds_D068_12700; cds_D068_12710] FIG01232970: hypothetical protein;
hypothetical protein; Possible ortholo:

$\begin{array}{lll}\text { cds_D068_12700 BSU12410 } & \begin{array}{l}\text { hypothetical protein; Possible o } \\ \text { BATR1942_03850 from Bacillus }\end{array}\end{array}$

$\begin{array}{ll}\text { cds_D068_12700 BSU12410 } & \begin{array}{l}\text { BATR1942_03850 from } \\ \text { cds_D068_12710 }\end{array} \\ \text { hypothetical protein; }\end{array}$

175: [cds_D068_13310]

$$
\text { cds_D068_13310 }
$$

unknown; unknown

Acyl-CoA hydrolase EC 3.1.2.20; YkhA;

176: [cds_D068_13460]

$$
\text { cds_D068_13460 }
$$$$
\text { BSU13030 }
$$

ossible ortholog: BATR1942_04200 fro

177: [cds_D068_13590]

$$
\text { cds_D068_13590 }
$$

\section{Organic hydroperoxide resistance}

cds_D068_13590 BSU13150 $\begin{aligned} & \text { transcriptional regulator; OhrR; Possible } \\ & \text { ortholog: BATR1942_04265 from Bacillus }\end{aligned}$

178: [cds_D068_13790]

$$
\text { cds_D068_13790 BSU13310 transcriptional regulator }
$$

179: [cds_D068_13940]

$$
\text { cds_D068_13940 BSU13490 heat shock protein HtpX }
$$

180: [cds_D068_14120]

cds_D068_14120

Transcriptional regulator, MarR family, transcriptional regulator MarR family protein; Possible ortholog: BATR1942_04590

181: [cds_D068_14700]

$$
\begin{array}{ll}
\text { protein; putative 2-cys peroxiredoxin; } \\
\begin{array}{l}
\text { Possible ortholog: BATR1942_04875 fro } \\
\text { Bacillus }
\end{array}
\end{array}
$$

182: [cds_D068_14890]

$$
\text { cds_D068_14890 }
$$


183: [cds_D068_14960]

\section{Abh; Putative transition state regulator $\mathrm{Abh}$}

[cds_ 068 15170)

$\begin{array}{ll} & \text { FIG01108286: hypothetical protein; } \\ & \text { hypothetical protein; Possible ortholog: }\end{array}$

185: [cds_D068_15630]

$$
\begin{array}{ll} 
& \begin{array}{l}
\text { COG1399 protein in cluster with ribosomal } \\
\text { protein L32p, Firmicutes subfamily; } \\
\text { hypothetical protein; Possible ortholog: }
\end{array} \\
\text { BATR1942_05325 from Bacillus }
\end{array}
$$

186: [cds_D068_15980; cds_D068_15970; cds_D068_15960; cds_D068_15950]

\begin{tabular}{|c|c|c|}
\hline & & $\begin{array}{l}\text { SSU ribosomal protein S2p SAe; 30S } \\
\text { ribosomal protein S2. Possible orthol }\end{array}$ \\
\hline
\end{tabular}

$$
\begin{aligned}
& \begin{array}{l}
\text { Yggt; Integral membrane protein YggT, } \\
\text { involved in response to extracytoplasmic }
\end{array} \\
& \begin{array}{lll}
\text { Cds_D068_15980 BSU15400 } & \begin{array}{l}
\text { stress osmotic shock; YlmG; Possible } \\
\text { ortholog: BATR1942_05495 frombacillus }
\end{array}
\end{array} \\
& \text { FIG001960: FtsZ-interacting protein related } \\
& \text { to cell division; cell division machinery } \\
& \begin{array}{lll} 
& \text { factor; Possible ortholog: BATR1942_05490 } \\
\text { cds_D068_15970 BSU15390 } & \text { from Bacillus; }
\end{array} \\
& \text { Hypothetical protein YggS, proline synthase } \\
& \text { co-transcribed bacterial homolog PROS } \\
& \begin{array}{lll}
\text { Cds_D068_15960 BSU15380 } & \begin{array}{l}
\text { hypothetical protein; Possible orthol } \\
\text { BATR1942_05485 from Bacillus; }
\end{array}
\end{array} \\
& \text { FIG01197458: hypothetical protein; } \\
& \text { cds_D068 15950 hypothetical protein; Possible ortholog: }
\end{aligned}
$$

187: [cds_D068_17100]

SSU ribosomal protein S2p SAe; $30 \mathrm{~S}$

188: [cds_D068_17660; cds_D068_17650; cds_D068_17640]

$$
\text { YMCA protein; master regulator for biofilm }
$$

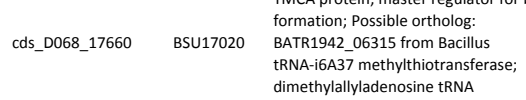

cds_D068_17650 BSU17010 $\begin{aligned} & \text { dimethylallyladenosine thethylthiotransferase; } \\ & \text { meta }\end{aligned}$

Chloramphenicol acetyltransferase EC 2.3.1.28; hypothetical protein; Possible
ortholog: BATR1942_06305 from Bacillus;

189: [cds_D068_17910]

FIG01239751: hypothetical protein;
hypothetical protein; Possible ortholog:

$\begin{array}{lll}\text { cds_D068_17910 BSU17240 } & \begin{array}{l}\text { hypothetical protein; Possible orth } \\ \text { BATR1942_06425 from Bacillus }\end{array}\end{array}$

190: [cds_D068_19520]

FIG01228874: hypothetical protein; putative

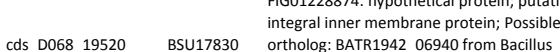

191: [cds_D068_19610; cds_D068_19600]
cds_D068_19610
Yoxg; alternate gene name: yoxG; unknown;
unknown
yoxf; alternate gene name: yoxF;
$\begin{array}{lll}\text { cds_D068_19600 BSU17900 } & \text { hypothetical protein; Possible } \\ \text { BATR1942_06980 from Bacillus; }\end{array}$

192: [cds_D068_19650; cds_D068_19640; cds_D068_19630]

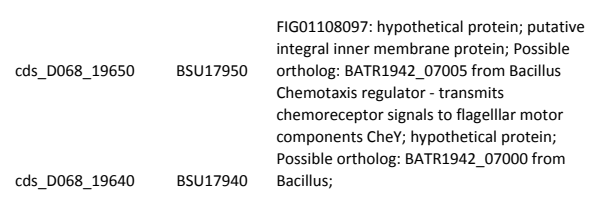

ccdA; Cytochrome c-type biogenesis protein CcdA DsbD analog; cytochrome c-type

biogenesis protein CcdA; Possible ortholo:

193: [cds_D068_19790]

Succinyl-CoA synthetase, alpha subunit-

related enzymes; putative CoA-binding
protein; Possible ortholog: BATR1942 07075

cds_D068_19790 BSU18080 from Bacillus

194: [cds_D068_20880]

cds_D068_20880 hypothetical protein

195: [cds_D068_20960]

cds_D068_20960

Pneumococcal vaccine antigen $\mathrm{A}$ homolog: putative transposon-related lytic enzyme; Possible ortholog: BATR1942_08235 from

196: [cds_D068_20970]

$$
\begin{array}{ll}
\text { FIG01234361: hypothetical protein; putative } \\
\text { integral inner membrane protein; Possible } \\
\text { ortholog: BATR1942_08240 from Bacillus }
\end{array}
$$

$3.09 \quad 2.18 \mathrm{E}-04$ UP

Not regulated Not regulated Not regulated Not regulated SigM, SigX

SigW, SigX

2.6 5.69E-05 UP Not regulated Not regulated Not regulated Not regulated 
197: [cds_D068_21050]

$$
\begin{array}{lll}
\text { Cds_D068_21050 BSU19210 } & \begin{array}{l}
\text { Cell wall-binding protein; YocH; Possible } \\
\text { ortholog: BATR1942_08285 from Bacillus }
\end{array}
\end{array}
$$

$2.28 \quad 1.19 \mathrm{E}-03$ UP

Not regulated Not regulated DoWN

Not regulated

198: [cds_D068_21100]

$$
\begin{array}{lll}
\text { unknown; hypothetical protein; Possible } \\
\text { cds_D068_21100 BSU19290 } & \text { ortholog: BATR1942_08310 from Bacillus }
\end{array}
$$

199: [cds_D068_21120

200: [cds_D068_21940]

Transcriptional regulator, Mark family,

family; Possible ortholog: BATR1942_0870

cds_D068_21940 BSU21700 from Bacillus

$5.17 \quad 2.70 \mathrm{E}-06 \mathrm{U}$

Not regulated Not regulated Not regulated Not regulated

201: [cds_D068_21960; cds_D068_21970; cds_D068_21980; cds_D068_21990]

Uncharacterized protein ypmT; hypothetical

ds 2068 protein; Possible ortholog: BATR1942_08710

cds_D068_21960 BSU21720 from Bacillus

Cds_D068_21970 BSU21730 $\begin{aligned} & \text { yfaA; YfaA; hypothetical protein; Possible } \\ & \text { ortholog: BATR1942_08715 from Bacillus; }\end{aligned}$

FIG006988: Lipase/Acylhydrolase with GDSL-

like motif; putative exported

$\begin{array}{cl} & \begin{array}{l}\text { like motif; putative exported } \\ \text { lipase/acylhydrolase; Possible ortholog: } \\ \text { cds_D068_21980 BSU21740_08720 from Bacillus; }\end{array}\end{array}$

sco1; Cytochrome oxidase biogenesis protein

Sco1/SenC/PrrC, putative copper

metallochaperone; assembly factor BSco of

the CuA site of cytochrome; Possible

cds_D068_21990 BSU21750 ortholog: BATR1942_08725 from Bacillus;

202: [cds_D068_22190]

SacB; activation of degradative enzymes;

cds_D068_22190 BSU21940 $\begin{aligned} & \text { hypothetical protein; Possible or } \\ & \text { BATR1942_08820 from Bacillus }\end{aligned}$

203: [cds_D068_22460; cds_D068_22470]



cds $D 068$ _22470 BSU22190

204: [cds_D068_23280]

$\begin{array}{ll}\text { FIG00895122: hypothetical protein; protease } & \text { required for RsiW anti-sigmaW; Possible }\end{array}$

205: [cds_D068_23390; cds_D068_23400]

ortholog: BATR1942_09350 from Bacillus

$2.06 \quad 3.65 E-03$ UP

Not regulated Not regulated Not regulated Not regulated

Substrate-specific component RibU of

riboflavin ECF transporter; FMN permease; $\begin{array}{lll} & & \begin{array}{l}\text { Piboflavin ECF transporter; } \\ \text { Cossible ortholog: BATR1942_09405 from } \\ \text { Bacillus }\end{array} \\ & \text { hypothetical protein; Possible ortholog: } \\ \text { BATR1942_09410 from Bacillus; }\end{array}$

$3.59 \quad 3.68 \mathrm{E}-06$ UP

Not regulated Not regulated Not regulated Not regulated

$6.93 \quad 1.58 \mathrm{E}-04+$

206: [cds_D068_23580]

RibT protein; putative acetyltransferas

Possible ortholog: BATR1942_09500 from

cds_D068_23580 BSU23240 Bacillus

$2.87 \quad 0$ UP

$2.04 \quad 4.74 E-04$ UP

$\begin{array}{lll} & & \begin{array}{l}\text { peptidase; Possible ortholog: } \\ \text { cds_D068_23650 }\end{array} \text { BSU23310 } \\ \text { BATR1942_09535 from Bacillus }\end{array}$

208: [cds_D068_23670]

Cres: Possibbe ortholog: BATR1942_09545

209: [cds_D068_23710]

$$
\begin{array}{ccl} 
& \begin{array}{l}
\text { Holin associated hypothetical protein; } \\
\text { hypothetical protein; Possible ortholog } \\
\text { BATR1942_09555 from Bacillus }
\end{array}
\end{array}
$$

cds_D068_23710 BSU07380 hypothetical protein, Possible ortholo

210: [cds_D068 23940]

erric uptake regulation protein FUR; Fur

cds_D068_23940 BSU23520 $\begin{aligned} & \text { family transcriptional regulator Fur; Possil } \\ & \text { ortholog: BATR1942_10045 from Bacillus }\end{aligned}$

211: [cds_D068_24390; cds_D068_24380]

Inner membrane protein translocas component YidC, OxaA protein; OxaA-like

$\begin{array}{lll} & \text { protein precursor; Possible ortholog: } \\ \text { Cds_D068_24390 BSU23890 } & \text { BATR1942_10255 from Bacillus }\end{array}$

$\begin{array}{lll}\text { cds_D068_24380 } & \text { BSU23880 } & \text { yqz; Y Y } \\ \text { BATR1942_10250 fromBacillus; }\end{array}$

212: [cds_D068_24670] 


$\begin{array}{cl} & \begin{array}{l}\text { Glycerophosphoryl diester } \\ \text { phosphodiesterase EC 3.1.4.46; } \\ \text { glycerophosphoryl diester } \\ \text { phosphodiesterase; Possible ortholog: }\end{array} \\ \text { BATR1942_10395 from Bacillus }\end{array}$

213: [cds_D068_25080]

$$
\begin{array}{crl} 
& \begin{array}{l}
\text { Rhodanese-like domain protein; putative } \\
\text { sulfur transferase; Possible ortholog: }
\end{array} \\
\text { cds_D068_25080 BSU24540 } & \text { BATR1942_10585 from Bacillus }
\end{array}
$$

214: [cds_D068_25150; cds_D068_25140]

Sinr; SinR, regulator of post-exponentialphase responses genes 0 sporulation; HTH-type transcriptiona

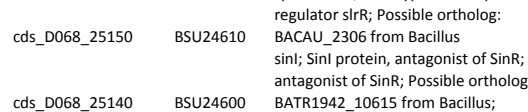

215: [cds_D068_25470]

BATR1942_10615 from Bacillus;

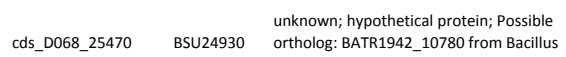

216: [cds_D068_25560]

Manganese superoxide dismutase EC
1.15.1.1; superoxide dismutase; Possible

cds_D068_25560 BSU25020 $\quad \begin{aligned} & \text { 1.15.1.1; superoxide dismutase; Possible } \\ & \text { ortholog: BATR1942_10825 from Bacillus }\end{aligned}$

217: [cds_D068_25630]

Zinc uptake regulation protein ZUR;

transcriptional regulator Fur family protein

cds_D068_25630 BSU25100 Bacillus

218: [cds_D068_25930; cds_D068_25940; cds_D068_25950]

$\begin{array}{cll} & \begin{array}{l}\text { FIG01232279: hypothetical protein; } \\ \text { hypothetical protein; Possible ortholog: } \\ \text { BATR1942_10995 from Bacillus }\end{array}\end{array}$

BATR1942_10995 from Bacillus

DUF1432 domain-containing protein;

$\begin{array}{lll} & \text { hypothetical protein; Possible ortholog: } \\ \text { cds_D068_25940 BSU25380 } & \text { BATR1942_11000 from Bacillus; }\end{array}$

FIG01107945: hypothetical protein; putative

mound hydrolase; Possible

cds_D068_25950 BSU25390 $\begin{aligned} & \text { membrane bound hydrolase; Possible } \\ & \text { ortholog: BATR1942_11005 from Bacillus; }\end{aligned}$

219: [cds_D068_25960; cds_D068_25970]

$\begin{array}{ccl} & \begin{array}{l}\text { Gatb; } \text { Transamidase GatB domain protein; } \\ \text { hypothetical protein; Possible ortholog: } \\ \text { BATR1942_11010 from Bacillus } \\ \text { SSU ribosomal protein S21p; 30S ribosomal } \\ \text { crotein S21; Possible ortholog: }\end{array} \\ \text { BAXH__02662 from; }\end{array}$

220: [cds_D068_26050; cds_D068_26060; cds_D068_26070) Hrca; Heat-inducible transcription repressor Possible ortholog. BATR1942 11055 from

cds_D068_26050 BSU25490 Bassill

Putative coproporphyrinogen III oxidase of BS HemN-type, oxygen-independent EC 1.3.99.22, in heat shock gene cluster,

$\begin{array}{lll}\text { cds_D068_26060 BSU25500 } & \begin{array}{l}\text { coproporphyrinogen III oxidase; Possible } \\ \text { ortholog: BATR1942_11060 from Bacillus; }\end{array}\end{array}$

lepA; Translation elongation factor LepA; GTP-binding protein LepA; Possible ortholo

$\begin{array}{lll}\text { cds_D068_26070 BSU25510 } & \text { GTP-binding protein LepA, Possib4_11065 from Bacillus; }\end{array}$

221: [cds_D068_26110]

SSU ribosomal protein S20p; 30S ribosoma

$\begin{array}{lll} & \text { protein S20; Possible ortholog: } \\ \text { cds_D068_26110 BSU25550 } & \text { BATR1942_11085 from Bacillus }\end{array}$

222: [cds_D068_26400]

cds_D068_26400 BSU31030 $\begin{aligned} & \text { unknown; hypothetical protein; Possible } \\ & \text { ortholog: BATR1942_13330 from Bacillus }\end{aligned}$

223: [cds_D068_27510]

FIG01233475: hypothetical protein; putative

cds_D068_27510 BSU27780 $\begin{aligned} & \text { serine/threonine-protein kinase; Possible } \\ & \text { ortholog: BATR1942_11620 from Bacillus }\end{aligned}$

224: [cds_D068_28080]

Clpx; ATP-dependent Clp protease ATP

binding subunit ClpX; ATP-dependent

$\begin{array}{lll}\text { cds_D068_28080 BSU28220 } & \begin{array}{l}\text { protease ATP-binding subunit ClpX; Possib } \\ \text { ortholog: BATR1942_11880 from Bacillus }\end{array}\end{array}$

225: [cds_D068_28370]

Thioredoxin reductase EC 1.8.1.9;

$\begin{array}{lll}\text { cds_D068_28370 } & \text { BSU28500 } & \begin{array}{l}\text { thioredoxin; Possible ortholog: } \\ \text { BATR1942_12010 from Bacillus }\end{array}\end{array}$

226: [cds_D068_28760]

IG01231657: hypothetical protein

hpothetical protein; Possible ortholo:

$\begin{array}{lll}\text { cds_D068_28760 } & \text { BSU28830 } & \text { hypothetical protein; Possible ort } \\ \text { BATR1942_12195 from Bacillus }\end{array}$

$2.2 \quad 2.55 \mathrm{E}-04 \mathrm{UP}$

Not regulated Not regulated Not regulated Not regulated

CodY, SigH, SigW

$2.32 \quad 1.79 \mathrm{E}-03$ UP Not regulated Not regulated Not regulated Not regulated

$3.13 \quad 1.40 \mathrm{E}-05$

Not regulated Not regulated Not regulated Not regulated

SpoOA

RocR, Sigh

$2.3 \quad 4.96 E-03$ UP

Not regulated Not regulated Not regulated DOWN

$2.96 \quad 0$ UP

Not regulated Not regulated Not regulated Not regulated

SigB

SigE

$2.31 \quad 9.26 \mathrm{E}-04 \mathrm{UP}$

Not regulated Not regulated Not regulated Not regulated

LexA

$2.13 \quad 1.04 E-03$ UP

Not regulated Not regulated Not regulated Not regulated

Not regulated Not regulated Not regulated Not regulate

Not regulated Not regulated Not regulated Not regulated 
227: [cds_D068_28780; cds_D068_28790; cds_D068_28800]

\begin{tabular}{|c|c|c|c|c|}
\hline \multirow[b]{2}{*}{ cds_D068_28780 } & & $\begin{array}{l}\text { LSU ribosomal protein L20p; } 50 \text { S ribosomal } \\
\text { protein L20; Possible ortholog: }\end{array}$ & & \\
\hline & BSU28850 & BAXH7_02903 from Bacillus & 2.61 & 8.83E-05 UP \\
\hline cds D068 28790 & BSU28860 & $\begin{array}{l}\text { LSU ribosomal protein L35p; } 50 \text { S ribosomal } \\
\text { protein L35; Possible ortholog: } \\
\text { BATR1942 } 12210 \text { from Bacillus: }\end{array}$ & 1.71 & 0.01 \\
\hline & & $\begin{array}{l}\text { Translation initiation factor 3; translation } \\
\text { initiation factor IF-3; Possible ortholog: }\end{array}$ & & \\
\hline ds D068 28800 & SU28870 & BACAU_2610 from Bacillus; & 1.52 & 0.02 \\
\hline
\end{tabular}

228: [cds_D068_28960]

\begin{abstract}
S-adenosylmethionine decarboxylase proenzyme EC 4.1.1.50, prokaryotic class 1B; S-adenosylmethionine decarboxylase proenzyme; Possible ortholog: BSU29010

cds_D068_28960 BSU29010 $\begin{aligned} & \text { proenzyme; Possible } \\ & \text { from Bacillus subtilis }\end{aligned}$
\end{abstract}

229: [cds_D068_29850; cds_D068_29860; cds_D068_29870]

$$
\begin{aligned}
& \text { general stress protein; hypothetical protein } \\
& \text { cds_D068_29850_Possible ortholog: BATR1942_12690 from } \\
& \begin{array}{ll}
\text { Bacillus } \\
\text { general stress protein; hypothetical protein }
\end{array} \\
& \text { cds_D068_29860_BSU29770 Possible ortholog: BATR1942_12695 from } \\
& \begin{array}{l}
\text { General stress protein; hypothetical protein; } \\
\text { Gecill }
\end{array} \\
& \text { cds_D068_29870 BSU29780 Possible ortholog: BATR1942_12700 from }
\end{aligned}
$$

230: [cds_D068_29950]

$$
\begin{array}{lll} 
& \text { hypothetical protein; YtzB; Possible ortholog: } \\
\text { cds_D068_29950 BSU29870 } & \text { BATR1942_12740 from Bacillus }
\end{array}
$$

231: [cds_D068_30400]

$$
\begin{aligned}
& \text { RsbR2; RsbR, positive regulator of sigma-B; } \\
& \text { blue light GTP-binding receptor; Possible }
\end{aligned}
$$

cds_D068_30400 BSU30340 blue light GTP-binding receptor; Possible

232: [cds_D068_30750]

$$
\begin{array}{ll} 
& \text { Luxs; S-ribosylhomocysteine lyase EC } \\
& \text { 4.4.1.21/Autoinducer-2 production protei } \\
\text { LuxS; S-ribosylhomocysteinase; Possible } & \\
\text { cds_D068_30750 BSU30670 } & \text { ortholog: BATR1942_13125 from Bacillus }
\end{array}
$$

233: [cds_D068_31340]

Thioredoxin reductase EC 1.8.1.9; putative thioredoxin or thiol-disulfide isomerase; Possible ortholog: BATR1942_21010 from

$$
\text { cds_D068_31340 BSU04550 } \quad \begin{aligned}
& \text { Possible } \\
& \text { Bacillus }
\end{aligned}
$$

234: [cds_D068_31390; cds_D068_31400; cds_D068_31410]

$$
\begin{aligned}
& \text { unknown; YdbL; Possible ortholog: } \\
& \text { BATR1942_20985 from Bacillus } \\
& \begin{array}{lll} 
& & \begin{array}{l}
\text { Possible ortholog: BATR1942_20980 from } \\
\text { cds_D068_31400 BSU04500 }
\end{array} \\
\text { Baillus; }
\end{array} \\
& \text { ABC transporter, ATP-binding protein; } \\
& \begin{array}{l}
\text { putative ABC transporter ATP-binding } \\
\text { protein; Possible ortholog: BATR1942_20975 }
\end{array} \\
& \text { cds_D068_31410 BSU04490 } \quad \begin{array}{l}
\text { protein; Possible } \\
\text { from Bacillus; }
\end{array}
\end{aligned}
$$

235: [cds_D068_33830]

$$
\text { cds_D068_33830 BSU32220 NifU-like domain protein }
$$

236: [cds_D068_34560; cds_D068_34570; cds_D068_34580; cds_D068_34590

cds_D068_34560 BSU32780 Toprim domain protein

$\begin{array}{lll}\text { cds_D068_34570 } & \text { BSU32790 } & \text { FIG109201: Hypothetical protein; } \\ \text { cds_D068_35580 } & \text { BSS3280 } & \text { Glycine cleavage system H protein; }\end{array}$

$\begin{array}{lll}\text { cds_D068_34580 } & \text { BSU32800 } & \text { Glycine cleavage system H protein } \\ \text { cds_D068_34590 } & \text { BSU32810 } & \text { Arsenate reductase EC 1.20.4.1; }\end{array}$

237: [cds_D068_35180; cds_D068_35190]

$$
\begin{array}{lll}
\text { Cds_D068_35180_DSU33340 } & \text { Sspj; SspJ }
\end{array}
$$

238: [cds_D068_35260]

$$
\begin{array}{lll}
\text { cds_D068_35260 BSU33400 } & \begin{array}{l}
\text { oxidoreductase of aldo/keto reductase } \\
\text { family, subgroup 1 }
\end{array}
\end{array}
$$

239: [cds_D068_35560]

$$
\begin{array}{lll} 
& & \text { Preprotein translocase subunit SecG TC } \\
\text { cds_D068_35560 } & \text { BSU33630 } & \text { 3.A.5.1.1 }
\end{array}
$$

240: [cds_D068_35610; cds_D068_35600; cds_D068_35590]

$$
\text { cds_D068_35610 BSU33680 Transcriptional regulator, HXIR family }
$$$$
\text { cds_D068_35600 BSU33670 YVAO prote }
$$

241: [cds_D068_35950; cds_D068_35960]

$$
\begin{array}{ccl} 
& \text { NAD-dependent glyceraldehyde-3- } \\
\text { cds_D068_35950 } & \text { BSU33940 } & \text { phosphate dehydrogenase EC 1.2.1.11 } \\
\text { cds_D068_35960 } & \text { BSU33950 } & \text { Central glycolytic genes regulator. }
\end{array}
$$

242: [cds_D068_36420]

$$
\begin{aligned}
& \text { Bds_D068_36420] } \\
& \text { cds_D068_36420 BSU34480 Transcriptional regulator, TetR family }
\end{aligned}
$$

243: [cds_D068_36470]

$$
\begin{array}{lll} 
& \text { ATP-dependent Clp protease proteolytic } \\
\text { cds_D068_36470 } & \text { BSU34540 } & \text { subunit EC 3.4.21.92 }
\end{array}
$$

244: [cds_D068_36650]

$$
\text { cds_D068_36650 BSU34790 Thioredoxin reductase EC 1.8.1.9 }
$$

245: [cds_D068_37200]

$$
\text { cds_D068_37200 BSU37010 } \quad \begin{aligned}
& \begin{array}{l}
\text { Peptide chain release factor 2; programmed } \\
\text { frameshift-containing }
\end{array} \\
& \text {. }
\end{aligned}
$$

246: [cds_D068_37220]

$$
\begin{aligned}
& \text { BS_D068_37220] } \\
& \text { cds_D068_37220 }
\end{aligned}
$$

247: [cds_D068_37280]
Not regulated Not regulated Not regulated Not regulated

Not regulated Not regulated Not regulated Not regulated 
cds_D068_37280 BSU35360 Flaa; Flagellin protein FlaA

$2.15 \quad 0.01$ UP

DOWN

Not regula

$2.12 \quad 1.55 \mathrm{E}-03$ UP

Not regulated

Not regulated

Not regulated

Not regulated

249: [cds_D068_37680]

cds_D068_37680

ransferase EC 2.7.8.13

$3.19 \quad 0$ UP

Not regul

Not regulate

Not regulated

$3.52 \quad 1.96 \mathrm{E}-06 \mathrm{UP}$

250: [cds_D068_38410]
Not regulated Not regulated Not regulated Not regulated

$\operatorname{codY,~CSrA,~ScoC~}$

SigD

SigD

dds_D068_38410 BSU36330 unknown

New putative transcription regulation binding sites were identified in 200 bp loci up-stream of the first gene in the operon by using the software tools provided by DBTBS server (Shttp://dbtbs.hgc.jp/ Genes of operons are shown in brackets. Leading 'r' means that the operon is located on the reverse strand. Gene IDs are as in the genome submission to NCBI with accession CP011802. 